\title{
Project W-551 Interim Pretreatment System Technology Selection Summary Decision Report and Recommendation
}

\author{
E. A. Conrad \\ CH2M HILL Hanford Group, Inc. \\ Richland, WA 99352 \\ U.S. Department of Energy Contract DE-AC27-99RL14047 \\ $\begin{array}{lll}\text { EDT/ECN: } & \text { N/A } & \text { UC: } \\ \text { Cost Center: } & & \text { Charge Code: } \\ \text { B\&R Code: } & & \text { Total Pages: } 79\end{array}$
}

Key Words: Interim Pretreatment System, Project W-551, Early LAW, IPS, down-select, crossflow filtration, rotary microfiltration, fractional crystallization, caustic side solvent extraction, ion exchange

\begin{abstract}
This report provides the conclusions of the tank farm interim pretreatment technology decision process. It documents the methodology, data, and results of the selection of cross-flow filtration and ion exchange technologies for implementation in project W-551, Interim Pretreatment System. This selection resulted from the evaluation of specific scope criteria using quantitative and qualitative analyses, group workshops, and technical expert personnel.
\end{abstract}

TRADEMARK DISCLAIMER. Reference herein to any specific commercial product, process, or service by trade name, trademark, manufacturer, or otherwise, does not necessarly constitute or imply its endorsement, recommendation, or favoring by the United States Government or any agency thereof or its contractors or subcontractors.

Printed in the United States of America. To obtain copies of this document, contact: Document Control Services, P.O. Box 950, Mailstop H6-08, Richland WA 99352, Phone (509) 372-2420; Fax (509) 376-4989.

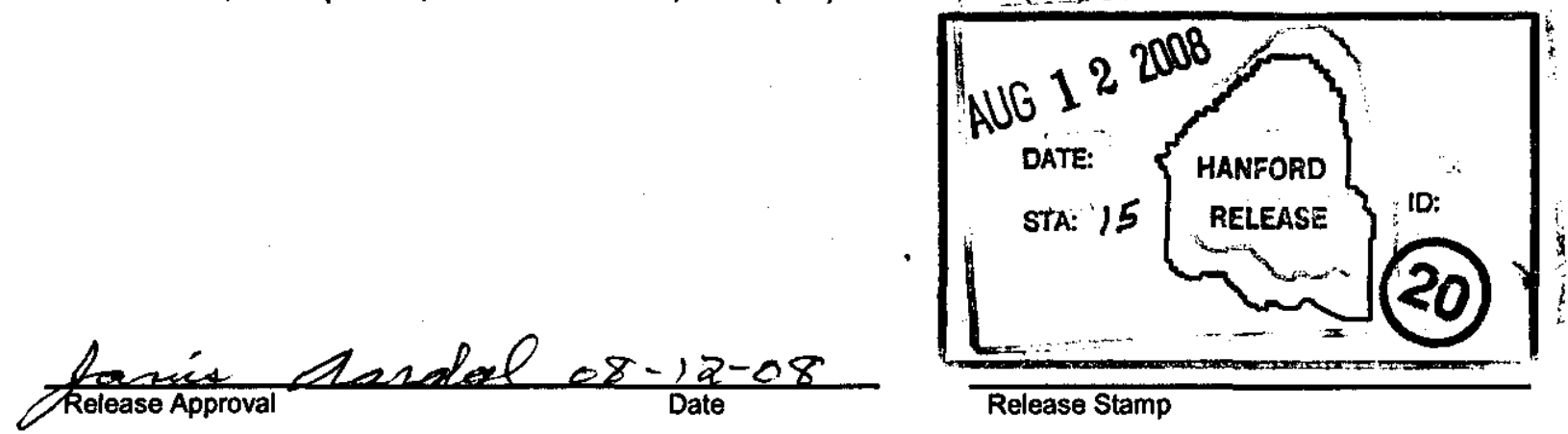

Approved For Public Release 


\begin{tabular}{|c|c|c|c|}
\hline \multicolumn{2}{|r|}{$\begin{array}{l}\text { Tank Farm Contractor (TFC) } \\
\text { RECORD OF REVISION }\end{array}$} & $\begin{array}{l}\text { (1) Document Number: } \\
\text { RPP-RPT-38057 }\end{array}$ & Page 1 \\
\hline \multicolumn{4}{|c|}{1 Interim Pretreatment System Technology Selection Summary Decision Report and } \\
\hline \multicolumn{4}{|c|}{ Change Control Record } \\
\hline \multirow{2}{*}{$\begin{array}{c}\text { (3) } \\
\text { Revision }\end{array}$} & \multirow{2}{*}{ (4) Description of Change - Replace, Add, and Delete Pages } & \multicolumn{2}{|c|}{ Authorized for Release } \\
\hline & & (5) Resp. Engr. (print/sign/date) & (6) Resp. Mgr. (print/sign/date) \\
\hline 0 RS & Initial Release & EA Conrad $A$ Conged 108 & Ka colosi faleris \\
\hline
\end{tabular}




\title{
Project W-551 Interim Pretreatment System Technology Selection Summary Decision Report and Recommendation
}

\author{
E. A. Conrad \\ CH2M HILL Hanford Group, Inc.
}

G. L. Dunford

S. Schaus

A E M Consulting, LLC.

Date Published

August 2008

\section{CH2MHILL \\ Hanford Group, Inc.}

Post Office Box 1500

Richland, Washington

Prepared for the U. S. Department of Energy

Assistant Secretary for Environmental Management

Project Hanford Management Contractor for the

U.S. Department of Energy under Contract DE-AC06-96RL13200

Approved for public release; distribution is unlimited 
RPP-RPT-38057, Rev. 0

This page intentionally left blank 
RPP-RPT-38057, Rev. 0

\section{EXECUTIVE SUMMARY}

This report documents the evaluation and recommendation to the Office of River Protection (ORP) for a new Interim Pretreatment System (IPS) in the Hanford tank farms to provide early feed to the Waste Treatment Plant, Low Activity Waste (LAW) vitrification facility. The recommended technologies are comprised of Cross-flow Filtration (CFF) for entrained solids removal and Ion Exchange for cesium separation, using spherical resorcinol-formaldehyde resin $(I X-s R F)$. Additionally, it is recommended that limited testing of Fractional Crystallization (FC) be continued to ensure an alternate cesium removal technology for reducing the risk of cost-effectively providing a waste feed supply to the Waste Treatment Plant. These recommendations are the product of a formal review process of the candidate technologies by CH2M HILL and involving ORP, and other stakeholders.

The recommendation of CFF over Rotary Micro-filtration (RMF) was based on two considerations: 1) that construction and installation of the CFF units will be performed in non-radioactive conditions (green field), while $R M F$ would require modification of an existing double shell tank (DST) pit and installation within a nuclear facility; and 2) that there is a high likelihood the RMF units will need to be replaced during the 5-year IPS mission.

The recommendation of $I X-s R F$ over Caustic-side Solvent Extraction (CSSX) and FC was based on the consideration that the earliest possible deployment of IPS could be achieved with the IX-sRF technology. Implementation schedules showed that IPS could be implemented approximately one year earlier if the $I X-s R F$ technology was selected over $F C$ and approximately two years earlier if $I X-s R F$ was selected over CSSX. Further, the $I X-s R F$ capital and life cycle costs were estimated to be significantly lower than the other two technologies. 


\section{Table of Contents}

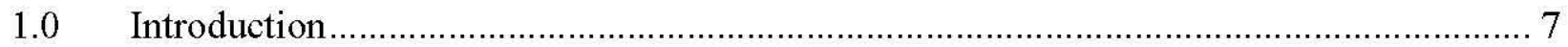

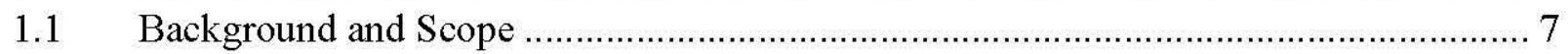

2.0 Decision Analysis Methodology (Process and Approach) ......................................... 8

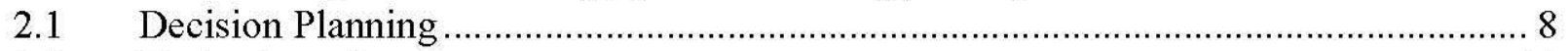

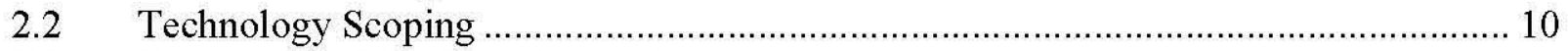

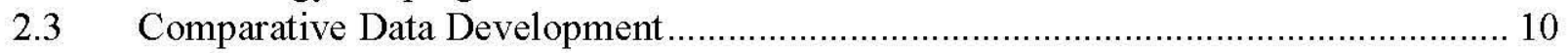

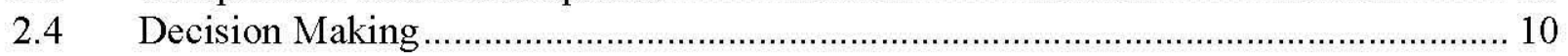

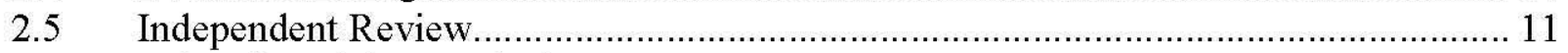

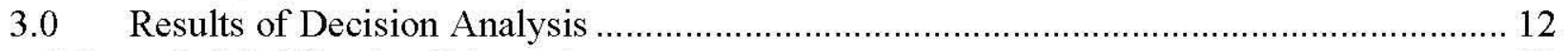

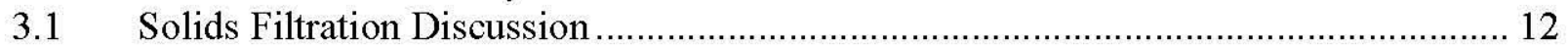

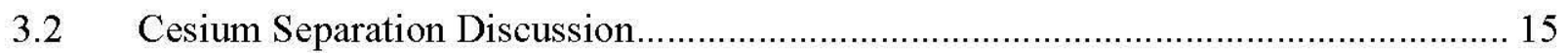

4.0 Expert Review Panel........................................................................................... 28

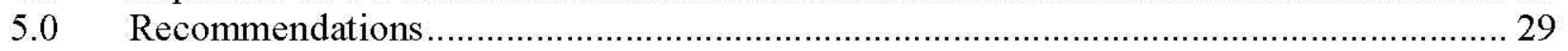

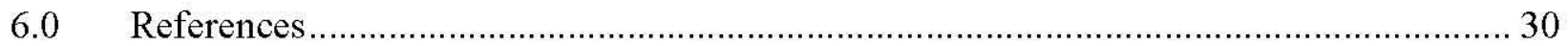

Attachment A. Solids Filtration Technology Decision Support Board Assessment ................ 31

Attachment B. Cesium Separation Technology Decision Support Board Assessment............ 45

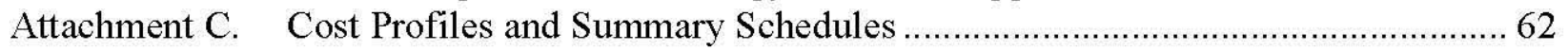

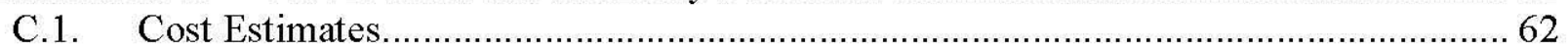

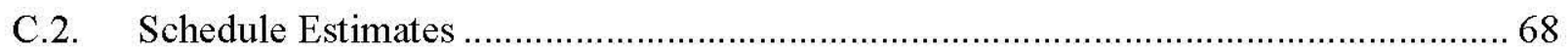

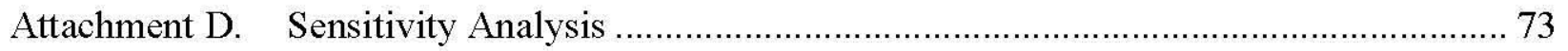

Attachment E. Decision Support Board Biographical Summaries .................................... 74

\section{List of Tables}

Table 3-1 - Solids Filtration Evaluation Results .................................................................. 12

Table 3-2 - Comparison of Safety Aspects for Solids Filtration.............................................. 13

Table 3-3 - Comparison of Technical Aspects for Solids Filtration ...................................... 14

Table 3-4 - Cs Separation Evaluation Results................................................................... 15

Table 3-5 - Comparison of Safety Aspects for Cesium Separation ........................................ 17

Table 3-6 - Comparison of Technical Aspects for Cesium Separation......................................... 20

Table 3-7 - Project Feed Volume and DST Space Recovered Over 5 Year IPS Mission............ 24

Table 4-1 - Comparison of Decision Board versus ERP......................................................... 28

Table A-1 - Solids Filtration Technology Assessment Matrix Summary ................................. 31

Table A-2 - Solids Filtration Technology Assessment Decision Calculator Results................. 41

Table B-1 - Cesium Separation Technology Assessment Summary Matrix............................. 45

Table B-2 - Cesium Separation Technology Assessment Decision Calculator .........................58

Table D-1 - Sensitivity Analysis for Solids Filtration Technologies ....................................... 73

Table D-2 - Sensitivity Analysis for Cs Separation Technologies........................................... 73 


\section{List of Figures}

Figure 2-1 - Decision Process Flowchart......................................................................... 8

Figure 3-1 - Comparison of Net Change in Available DST Waste Storage Space ....................... 22

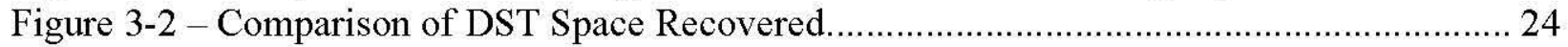

Figure 3-3 - Life-Cycle Cost Estimate Summary (for comparative purposes only) ………….... 26

Figure 3-4 - Implementation Schedule Duration Comparison .................................................. 27

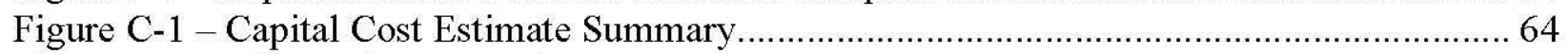

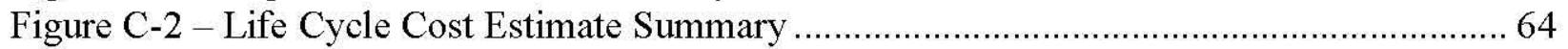

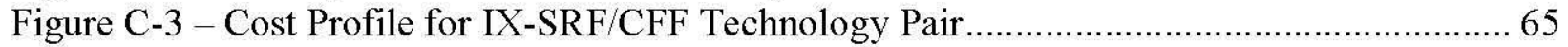

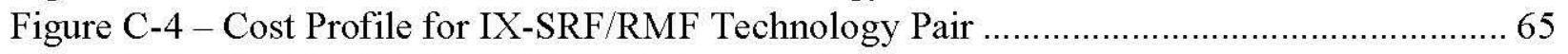

Figure C-5 - Cost Profile for FC/CFF Technology Pair.............................................................. 66

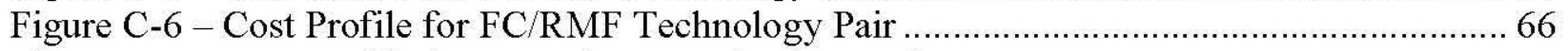

Figure C-7 - Cost Profile for CSSX/CFF Technology Pair ....................................................... 67

Figure C-8 - Cost Profile for CSSX/RMF Technology Pair .................................................... 67

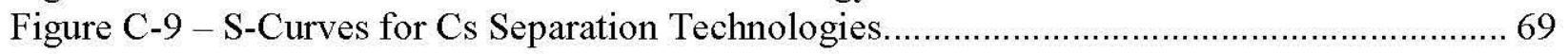

Figure C-10 - Implementation Schedule for IX-SRF ........................................................ 70

Figure C-11 - Implementation Schedule for FC ………………….............................. 71

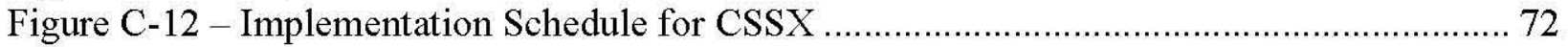




\section{List of Terms}

ALARA
Board
CH2M HILL
CFF
Cs
CSSX
D\&D
DOE
DST
ERP
ETF
FC
IPS
IX
LAW
MAR
Mgal
Na
NEPA
ORP
RMF
RPP
SEPA
SME
sRF
SST
STP
SU\&T
TBD
TPA
TRA
TRL
ULD
WTP
WDOE

As low as reasonably achievable

IPS Decision Support Board

CH2M HILL Hanford Group, Inc.

Cross-flow Filtration

Cesium

Caustic-side Solvent Extraction

Decontamination \& Decommissioning

U. S. Department of Energy

Double-shell tank

Expert Review Panel

Effluent Treatment Facility

Fractional Crystallization

Interim Pretreatment System

Ion Exchange

Low-activity waste

Materials at risk

Million gallons

Sodium

National Environmental Policy Act

Office of River Protection

Rotary Micro-filtration

River Protection Project

State Environmental Policy Act

Subject matter expert

Spherical resorcinol-formaldehyde

Single Shell Tank

Supplemental Treatment Project

Start Up \& Testing

To be determined or developed

Tri-Party Agreement

Technology Readiness Assessment

Technology Readiness Level

Unit liter dose

Waste Treatment Plant

Washington State Department of Ecology 


\subsection{INTRODUCTION}

This technology selection summary documents the basis for selection of cross-flow filtration (CFF) and ion-exchange using spherical resorcinol-formaldehyde (IX-sRF) resin as the recommended technologies for the two early Low Activity Waste (LAW) pretreatment functions (entrained solids removal and cesium separation, respectively) and provides the rationales for their respective selections.

\subsection{BACKGROUND AND SCOPE}

The Waste Treatment Plant (WTP) LAW Vitrification facility is currently scheduled for completion several years prior to completion of the WTP Pretreatment facility. The Office of River Protection (ORP) is evaluating the early start up and operation of the WTP LAW Vitrification facility along with supplemental treatment alternatives. To generate feed for LAW treatment, entrained solids removal and cesium separations (i.e., pretreatment) will be required (External letter, CH2M-0800043 R1 (CH2M HILL 2008a)). Early pretreatment is anticipated to be done in a new facility called Interim Pretreatment System (IPS). The IPS is envisioned to be a moderately-sized system which will filter entrained solids and separate cesium from several selected batches of Hanford tank waste. The IPS is expected to be operational several years prior to the hot startup of the WTP Pretreatment facility, thereby allowing accelerated processing of tank waste. However, the IPS is not intended to replace the WTP Pretreatment Facility, since the IPS will not have the full functionality or capacity of the WTP Pretreatment Facility.

A decision was required regarding which technologies for each of the two major technical objectives would be carried forward into the conceptual design of IPS. The selected technologies will necessarily undergo additional testing and further technology development for maturation prior to their deployment and implementation. To facilitate this selection process, ORP directed a study to evaluate and recommend processing options for Interim Pretreatment of LAW (External letter, 08-AMD-050 (ORP 2008a)). The results of that evaluation are summarized in this report.

The candidate technologies that were evaluated for the entrained solids removal function were:

- $\quad$ Rotary micro-filtration (RMF) and

- $\quad$ Cross-flow filtration (CFF)

The candidate technologies that were evaluated for the cesium separation function were:

- $\quad$ Fractional crystallization (FC),

- $\quad$ Caustic side solvent extraction (CSSX) and

- $\quad$ Ion-exchange using spherical resorcinol-formaldehyde (IX-sRF) resin 


\subsection{DECISION ANALYSIS METHODOLOGY (PROCESS AND APPROACH)}

The approach used to select the solids filtration and cesium separation technology was based on a tiered data development and assessment as shown in Figure 2-1 and described below.

\section{Figure 2-1 - Decision Process Flowchart}

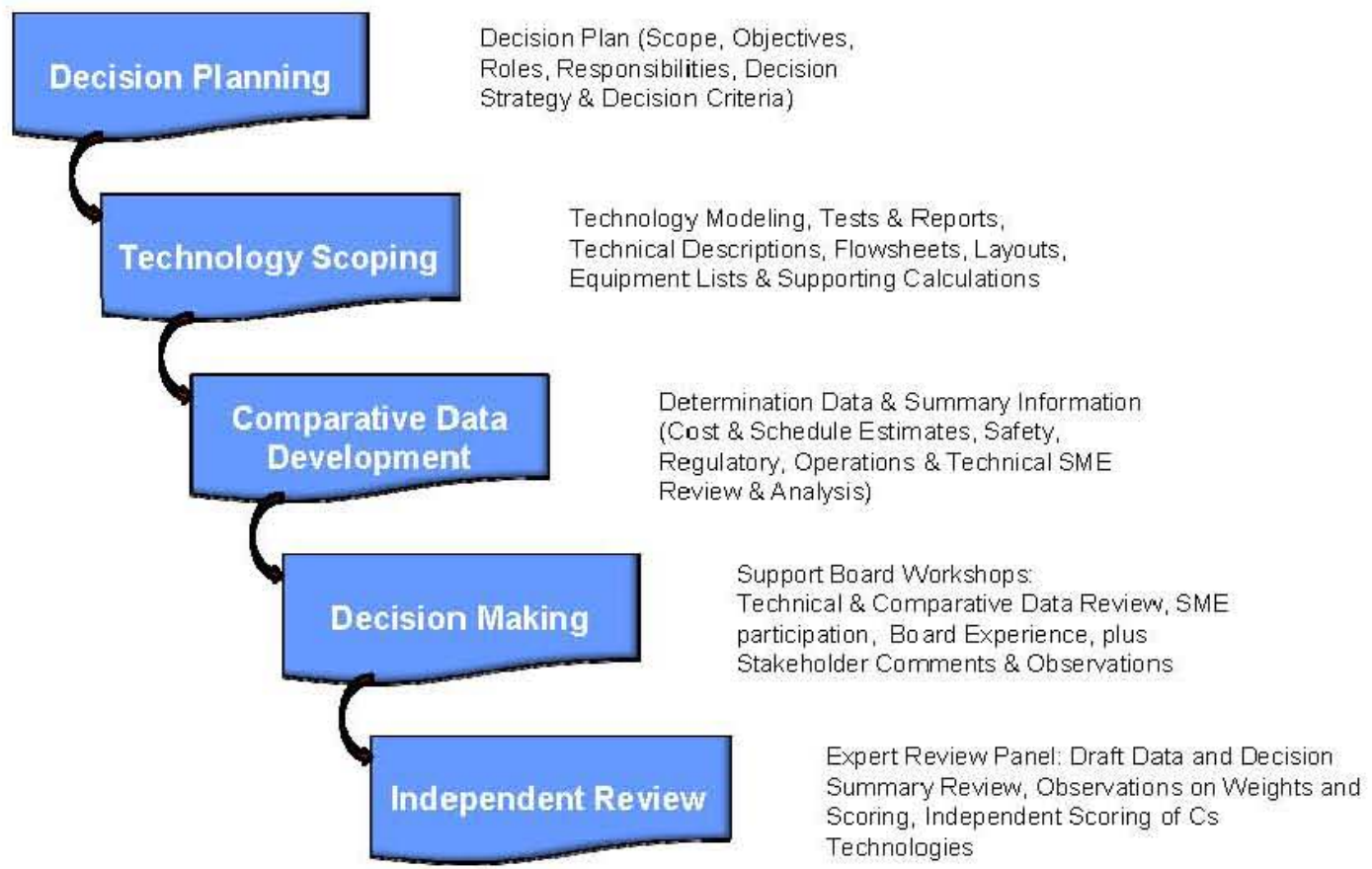

\subsection{DECISION PLANNING}

The decision planning process consisted of the development of the RPP-PLAN-37558, Decision Plan: Selection of Early LAW Interim Pretreatment System Process for Removal of Entrained Solids and Cesium (CH2M HILL 2008b) Decision Plan that defined and documents the scope, objectives, roles, responsibilities, decision strategy and decision criteria. The decision statement from the Plan is:

Select one entrained solids filtration technology and one cesium separation technology that can be used for the pre-conceptual design of the interim pretreatment system

The Decision Maker and members of the Decision Support Board (Board) were also identified in the Decision Plan (CH2M HILL 2008b). 
Decision maker: Ben Harp, Federal Project Director, ORP

Decision Support Board members (biographical information included in Attachment E):

- Jim Honeyman (Chairman)

- Jim Badden (operations)

- Kris Colosi (project)

- Beth Conrad (project)

- Felix Miera (regulatory policy)

- Rick Raymond (technology/ engineering)

- PK Brockman (senior management representative and alternate Chairman)

Measures and definitions were developed for each criterion with input provided by Decision Support Board (Board) members, subject matter experts and stakeholders during a workshop in April 2008 and formed the basis for the multi-attribute decision analysis performed to select the recommended technologies. Finally, weights were assigned to the criteria and measures based on the values from the participants.

The major criteria used to assess the technologies and the assigned weights are:

- Safety $(25 \%)$,

- Regulatory/Stakeholder Acceptance (20\%),

- Technical Maturity $(20 \%)$,

- Operability and Maintainability (15\%), and

- Programmatic Aspects (20\%)

Further detail the development of the Criteria, Measure and Definitions and respective weights is documented in the Decision Plan. 


\subsection{TECHNOLOGY SCOPING}

In parallel with the decision planning, technology scoping activities were undertaken for the candidate technologies to develop technical descriptions that included flowsheets, facility and equipment layouts. Existing tests and reports for each of the technologies were reviewed, additional testing and modeling was conducted and supporting calculations were performed to provide the foundation for the technical descriptions. The technology descriptions are documented in RPP-RPT-37551, Project $W$-551 Interim Pretreatment System Pre-Conceptual Candidate Technology Descriptions (CH2M HILL 2008c).

\subsection{COMPARATIVE DATA DEVELOPMENT}

Each of the definitions developed for the criteria and measures were then assessed by the SMEs assigned to each criterion. The SMEs reviewed and analyzed the technical scoping information using sub-teams, workshops and subcontractor experts and developed both quantitative and qualitative assessments of each of the candidate technologies. Cost and schedule estimates were also developed for each of the 6 technology pairs (i.e., each of the 2 solids separation technologies pairs with one of $3 \mathrm{Cs}$ separations technologies). The results of these assessments were documented in Assessment Summary Forms that were compiled by technology in RPP-RPT-37741, Project $W-551$ Determination Data for Early LAW Interim Pretreatment Selection (CH2M HILL 2008d). The data by technology was then compiled into cross cutting summaries that showed the evaluation data by criteria/measure/definition in order to facilitate the final assessment by the Board in RPP-RPT-37740, Project $W$-551 Summary Information for Early $L A W$ Interim Pretreatment System Selection, (CH2M HILL 2008e)

\subsection{DECISION MAKING}

The activities and documents described above provided a framework and served as the basis for evaluating and selecting pretreatment processes during the Technology Selection Workshops. The Workshops were conducted over 4 days in June 2008 and attended by the Board members and observers from ORP and Washington State Department of Ecology (W-DOE) staff. The Board performed their evaluation of the technologies using the technical and comparative data discussed above, discussion with the SMEs, and taking into account stakeholder comments and observations. Some minor changes were made to the Assessment forms and summary document as a result $(\mathrm{CH} 2 \mathrm{M}$ HILL 2008d and CH2M HILL 2008e). A scoring calculator was developed to record the raw scores and calculate the final weighted rankings for each technology (SVF-1520, IPS Decision Calculator Rev 1 with Workshop Data 6-18-08.xls (CH2M HILL 2008e)). The Board assigned ranks to the 71 Definitions in the following manner: 
- The ranking scores were generally assigned around a raw score of 5 (on a scale of 1 to 10) as being acceptable performance for the IPS mission; raw scores above or below 5 indicated the degree that a technology performed relative to the other technologies, rather than on an absolute scale.

- If a Definition was deemed to be a non-discriminator, all technologies were assigned a ranking score of 5 .

- In a few instances, if the Definition was determined to be redundant or of lesser importance relative to other Definitions within a Measure, the ranking scores were lowered to minimize the importance of the Definition,

- If a Definition or Measure was determined to be not applicable, then a score of 0 was assigned and the points redistributed within the Measure or Criterion to compensate.

The results from the Board evaluation are discussed in Section 3.0.

\subsection{INDEPENDENT REVIEW}

The initial draft of this document and the process used by the Board was reviewed in early July 2008 by an independent Expert Review Panel (ERP). The comments and observations from the ERP are summarized in Section 4.0. 


\subsection{RESULTS OF DECISION ANALYSIS}

The following two sections provide a discussion of the results by criterion for the entrained solids filtration technologies and cesium separation technologies, respectively.

\subsection{SOLIDS FILTRATION DISCUSSION}

This section summarizes the evaluations of the two entrained solids filtration technologies (cross-flow filtration and rotary micro-filtration) and their respective rankings. The summary weighted results are shown in Table 3-1 and the detailed evaluation information is provided in Attachment $\mathrm{A}$.

Table 3-1 - Solids Filtration Evaluation Results

\begin{tabular}{|l|c|c|c|}
\hline \multirow{2}{*}{ Criteria } & Criterion & \multicolumn{2}{|c|}{ Weighted Results } \\
\cline { 3 - 4 } & Weight & CFF & RMF \\
\hline Safety & $25 \%$ & 12 & 12 \\
\hline $\begin{array}{l}\text { Regulatory \& Stakeholder } \\
\text { Acceptance }\end{array}$ & $20 \%$ & 10 & 11 \\
\hline $\begin{array}{l}\text { Technical } \\
\text { Maturity/Flexibility }\end{array}$ & $20 \%$ & 12 & 11 \\
\hline $\begin{array}{l}\text { Operability and } \\
\text { Maintainability }\end{array}$ & $15 \%$ & 8 & 7 \\
\hline Programmatic Aspects & $20 \%$ & 12 & 8 \\
\hline Total & & $\mathbf{5 4}$ & $\mathbf{4 9}$ \\
\hline
\end{tabular}

\subsubsection{Safety}

The Safety criterion was divided into 3 Measures - process safety (further evaluated by 8 Definitions), criticality safety, and industrial safety and hygiene. Under the Safety criterion, Industrial Health and Safety and Criticality Safety criteria were nondiscriminators between the 2 technologies with identical scores; the process safety ranking differential between the two technologies was less than 1 point. The only noted comment from the Board meetings was the concern of performing in tank nitric acid cleaning on the RMF housing/disks. Neither of the technologies introduces a new or unique hazard that has not been encountered previously at the Hanford. Also neither technology represents any unusual or significant barriers to implementation from a safety systems design or licensing perspective.

A comparison of the Safety aspects of respective technologies is provided in Table 3-2. 
Table 3-2 - Comparison of Safety Aspects for Solids Filtration

\begin{tabular}{|c|c|c|}
\hline Safety Pros \& Cons & $\mathrm{CFF}$ & RMF \\
\hline Pros & $\begin{array}{l}\text { Fewer moving parts } \\
\text { Green field construction } \\
\text { Potentially less contact } \\
\text { maintenance required }\end{array}$ & $\begin{array}{l}\text { Lower flow rate pump } \\
\text { Less solids holdup }\end{array}$ \\
\hline Cons & $\begin{array}{l}\text { Higher flow rate pump } \\
\text { Greater solids holdup }\end{array}$ & $\begin{array}{l}\text { More moving parts } \\
\text { Potentially more contact } \\
\text { maintenance } \\
\text { Nitric acid wash } \\
\text { solutions are used for } \\
\text { filter cleaning - in tank } \\
\text { impacts require } \\
\text { evaluation } \\
\text { Seal life will require } \\
\text { that units be replaced at } \\
\text { least once during } 5 \text { year } \\
\text { mission } \\
\text { Construction in } \\
\text { radiological zone }\end{array}$ \\
\hline
\end{tabular}

\subsubsection{Regulatory and Stakeholder Acceptance}

The Regulatory and Stakeholder Acceptance criterion was divided into 2 Measures achieve Tribal Nations/stakeholder acceptance (further evaluated by 2 Definitions) and achieve regulator acceptance (4 Definitions).

No discrimination could be made between the solid/liquid separation technologies with respect to regulatory compliance (Definition 2.2.1), secondary waste (Definition 2.2.3), or impacts to other permitted facilities (Definition 2.2.4).

\subsubsection{Technical Maturity/Flexibility}

The Technical Maturity/Flexibility criterion was divided into 2 Measures - Technology Readiness Level (further evaluated by 3 Definitions) and process flexibility and robustness (6 Definitions).

Overall, the ranking differential between the two technologies was less than 1 point overall. The CFF technology readiness level score was slightly higher due to the shorter time schedule to mature the technology (Definition 3.1.2), while RMF was slightly better in the flexibility/robustness measure. CFF also scored higher because it is currently being used at several DOE sites and is planned for use at the WTP Pretreatment facility.

A comparison of the technical aspects of respective technologies is provided in Table 3-4. 
Table 3-3 - Comparison of Technical Aspects for Solids Filtration

\begin{tabular}{|l|l|l|}
\hline Technical Pros \& Cons & CFF & RMF \\
\hline Pros & $\begin{array}{l}\text { Slightly cheaper to } \\
\text { mature }\end{array}$ & $\begin{array}{l}\text { More flexibility to } \\
\text { adjust process rates }\end{array}$ \\
& $\begin{array}{l}\text { Easier to startup and } \\
\text { shutdown } \\
\text { - Easier recovery out of } \\
\text { spec product }\end{array}$ & \\
\hline Cons & $\begin{array}{l}\text { Less flexibility to adjust } \\
\text { process rates }\end{array}$ & $\begin{array}{l}\text { Slightly more expensive } \\
\text { to mature } \\
\text { Harder to startup and } \\
\text { shutdown }\end{array}$ \\
& & $\begin{array}{l}\text { Easier recovery out of } \\
\text { spec product }\end{array}$ \\
\hline
\end{tabular}

\subsubsection{Operability/Maintainability}

The Operability and Maintainability criterion was divided into 6 Measures - ease of process control (further evaluated by 10 definitions), ALARA, reliability ( 2 definitions), ease and frequency of maintenance ( 5 definitions), ease of implementation ( 3 definitions), and liquid/solid secondary waste ( 2 definitions).

Overall, the ranking differential between the two technologies was less than 1 point.. Ease of process control (Measure 4.1), Ease of implementation (Measure 4.5), and Secondary waste (Measure 4.6) were deemed to be non-discriminators between the technologies.

ALARA (Measure 4.2), Reliability (Measure 4.3), and Ease and frequency of maintenance (Measure 4.4) favored the CFF technology. This was primarily due to the extra rotating parts for the $\mathrm{RMF}$ and the service life of the rotating disk seals. The service life of the RMF seals becomes more of an issue if the FC process were to be selected as the cesium separation technology, since the number of RMF components increases by a factor of 3 .

\subsubsection{Programmatic Aspects}

The Programmatic Aspects criterion was divided into 6 Measures - cost impact (further evaluated by 3 Definitions), schedule impact (4 Definitions), DST space (2 Definitions), impacts to WTP/ Supplemental Treatment project (STP) (8 Definitions), impacts to other facilities (4 Definitions), and resources and materials (2 Definitions).

The majority of the (weighted) differences in the overall solid/liquid technologies were identified under this criterion. The cost evaluation was performed using paired costs, i.e., 
a solids removal technology paired with a Cs separation technology (see Section 2.2 .5 for Cost Estimate Summaries). The RMF consistently cost more to build (capital) because of the need to install the equipment in a radiologically-contaminated zone (i.e., the DST feed tank). The operating costs are also higher because of the projected need to change out the RMF units at least once in the 5-year IPS mission.

The other difference in the programmatic scoring was Schedule Impact (Measure 5.2) where the DOE complex experience with operating CFF systems increased the rating for the CFF technology.

The other measures, DST space, impact on WTP, impacts on other facilities, and resource and material were deemed to be either non-discriminators or not applicable.

\subsubsection{Solids Filtration Conclusion}

In summary, the Board selected CFF as recommended filtration technology for entrained solids removal, based on construction and installation in a non-radioactive field conditions and the high probability that the RMF units would require replacement at least once during the 5 year IPS mission period.

\subsection{CESIUM SEPARATION DISCUSSION}

This section summarizes the evaluations of the three cesium separations technologies (caustic-side solvent extraction, fractional crystallization, and ion exchange using spherical Resorcinol-Formaldehyde resin) and their respective rankings. The summary weighted results are shown in Table 3-4 and the detailed evaluation information is provided in Attachment B.

The following sections discuss the salient points that lead to the weighted rankings for each of the Criterion.

Table 3-4 - Cs Separation Evaluation Results

\begin{tabular}{|l|c|c|c|c|}
\hline \multirow{2}{*}{ Criteria } & Criterion & \multicolumn{3}{c|}{ Weighted Results } \\
\cline { 3 - 5 } & Weight & FC & CSSX & IX-sRF \\
\hline Safety & $25 \%$ & 13 & 11 & 11 \\
\hline $\begin{array}{l}\text { Regulatory \& Stakeholder } \\
\text { Acceptance }\end{array}$ & $20 \%$ & 11 & 9 & 11 \\
\hline $\begin{array}{l}\text { Technical } \\
\text { Maturity/Flexibility }\end{array}$ & $20 \%$ & 9 & 7 & 9 \\
\hline $\begin{array}{l}\text { Operability and } \\
\text { Maintainability }\end{array}$ & $15 \%$ & 8 & 6 & 8 \\
\hline Programmatic Aspects & $20 \%$ & 11 & 8 & 11 \\
\hline Total & & $\mathbf{5 1}$ & $\mathbf{4 1}$ & $\mathbf{5 0}$ \\
\hline
\end{tabular}


RPP-RPT-38057, Rev. 0

\subsubsection{Safety}

The Safety criterion was divided into 3 Measures - process safety (further evaluated by 8 Definitions), criticality safety, and industrial safety and hygiene.

The quantity of MAR (Definition 1.1.1), dispersive energy (Definition 1.1.4), and criticality safety (Definition 1.2.1) were deemed to be non-discriminators among the 3 technologies. Additionally none of the technologies will create new, or exacerbate any existing, Tank Farm hazards (Definition 1.1.6). However, a comparison of the three Cs separation technologies did rank the FC process somewhat higher overall for both the Process Safety and Industrial Safety \& Hygiene measures than either CSSX or IX-sRF, primarily because FC does not introduce any additional chemicals (e.g., solvents, resins) into the process (Definitions 1.1.8 and 1.3.1). In addition, the IX-sRF process rated lower than either FC or CSSX with regard to dispersabilty during a fire accident, because the $\mathrm{Cs}$ becomes concentrated over time on the resin column bed (Definition 1.1.3). Finally, because of the potential for a solvent-fueled fire, the CSSX process rated lower than either FC or IX-sRF (Definition 1.1.7).

Fractional crystallization (FC) received the highest weighted ranking, primarily because it uses no additional chemicals. The only area where FC received the lowest ranking was in the material at risk (MAR) concentration (Definition 1.1.2).

Caustic side solvent extraction (CSSX) received a weighted ranking slightly better than ion exchange (IX-sRF). In all but one case (MAR concentration), CSSX ranked equal to or lower than FC and only showed better performance than IX with respect to ease of shutdown. Additionally, CSSX was ranked the lowest on fire hazard (Definition 1.1.7).

For ion exchange, the quantity and type of chemicals (resin, caustic, and nitric acid) resulted in lower ranking than FC in the areas of fire hazard (Definition 1.1.7), reactive chemicals (Definition 1.1.8), and the industrial safety and hygiene measure (Definition 1.3.1). In the case of MAR dispersabilty (Definition 1.1.3) and process stability (Definition 1.1.5), IX was ranked the lowest of the three technologies, primarily due to concerns with the potential for hydrogen gas buildup in the IX columns if loaded with Cs.

Overall, the ranking differential among the three technologies was less than 2 points (i.e., FC -13 ; CSSX -11 ; IX -11 ). The Board noted that with regard to process safety, the toxicological doses are driven by the chemicals within the DST waste, not by the additional chemicals used by either CSSX or IX. None of the technologies introduce a new or unique hazard that has not been encountered previously at the Hanford site and successfully managed and controlled, nor do any of them represent any unusual or significant barriers to implementation from a safety systems design or licensing perspective.

A comparison of the safety aspects of respective technologies is provided in Table 3-5. 
RPP-RPT-38057, Rev. 0

Table 3-5-Comparison of Safety Aspects for Cesium Separation

\begin{tabular}{|c|c|c|c|}
\hline $\begin{array}{l}\text { Safety Pros \& } \\
\text { Cons }\end{array}$ & $\mathrm{FC}$ & CSSX & IX-sRF \\
\hline Pros & $\begin{array}{l}\text { No additional } \\
\text { chemicals } \\
\text { required } \\
\text { No combustibles } \\
\text { Easy shutdown } \\
\text { Moderate contact } \\
\text { maintenance }\end{array}$ & $\begin{array}{l}\text { Continuous } \\
\text { Operation } \\
\text { Easy shutdown }\end{array}$ & $\begin{array}{l}\text { Low system } \\
\text { complexity } \\
\text { Low contact } \\
\text { maintenance }\end{array}$ \\
\hline Cons & $\begin{array}{l}\text { Steam system } \\
\text { provides } \\
\text { dispersive energy } \\
\text { Unit liter dose } \\
\text { slightly higher } \\
\text { Potential for } \\
\text { solids formation } \\
\text { in return stream to } \\
\text { Tank Farms } \\
\text { Moderate system } \\
\text { complexity }\end{array}$ & $\begin{array}{l}\text { Organic solvent } \\
\text { has low flash } \\
\text { point and is a } \\
\text { potential fire } \\
\text { hazard } \\
\text { Requires nitric } \\
\text { acid and NaOH } \\
\text { High system } \\
\text { complexity } \\
\text { Significant } \\
\text { number of moving } \\
\text { parts/rotating } \\
\text { equipment } \\
\text { requiring contact } \\
\text { maintenance }\end{array}$ & $\begin{array}{l}\text { Requires column } \\
\text { venting to } \\
\text { preclude } \mathrm{H}_{2} \\
\text { buildup } \\
\text { Decay heat on } \\
\text { loaded column } \\
\text { increase fire } \\
\text { potential } \\
\text { Requires eluting } \\
\text { to remove } \mathrm{Cs} \\
\text { source term } \\
\text { during shutdowns } \\
\text { Requires nitric } \\
\text { acid and } \mathrm{NaOH}\end{array}$ \\
\hline
\end{tabular}

\subsubsection{Regulatory and Stakeholder Acceptance}

The Regulatory and Stakeholder Acceptance criterion was divided into 2 Measures achieve Tribal Nations/stakeholder acceptance (further evaluated by 2 Definitions) and achieve regulator acceptance (4 Definitions).

No discrimination could be made between the solid/liquid separation technologies with respect to regulatory compliance (Definition 2.2.1), secondary waste (Definition 2.2.3), or impacts to other permitted facilities (Definition 2.2.4).

Ion exchange received the highest ranking under this criterion, primarily because of the earliest enabling of LAW treatment (Definition 2.1.1), which included an assessed 'tried and true' technology based on stakeholder interactions and land usage (Definition 2.1.2) due to the smallest footprint for the facility. It ranked equally with CSSX with regard to disposal system performance (Definition 2.2.2); both were ranked significantly lower than FC in this area. 
Fractional crystallization ranked second, driven essentially by the removal of technetium (Tc) from the LAW product stream (Definition 2.2.3). It ranked higher than CSSX with respect to enabling early LAW treatment but equally with regard to land usage.

Finally, CSSX received the lowest ranking, basically due to land usage, and longer implementation schedule for enabling early LAW treatment.

Overall, the ranking differential among the three technologies was 2 points. Based on these results, there was no meaningful difference among the technologies and none of the technologies represent any unusual or significant barriers from a regulatory or stakeholder perspective to implementation. Moreover, while the Tc removal by FC is of major benefit, it should be noted that Te management is a significant regulatory issue, not just limited to early LAW, but one that requires a more systematic site-wide resolution. A separate effort is underway to resolve the Tc issue and is outside the scope of this assessment.

\subsubsection{Technical Maturity/Flexibility}

The Technical Maturity/Flexibility criterion was divided into 2 Measures - Technology Readiness Level (TRL) (further evaluated by 3 Definitions) and process flexibility and robustness (6 Definitions).

With respect to the technical maturity measurements, FC and IX-sRF were ranked equally on TRL (Measure 3.1) with CSSX slightly lower. The rankings were based on review of the previous EM-20 technical readiness assessments (TRA) for FC and IX-sRF and assessment of CSSX for application at Hanford by a senior technical team using the EM-20 methodology. Generally, FC and IX-sRF were deemed to have equivalent TRLs for application to IPS, even though FC had previously received a higher TRL during its assessment for application to Supplement Treatment. This determination was based on the demonstration of IX-sRF on real DST waste, while the FC work to date has been focused on SST salt cake feeds, rather than the DST supernate feeds for IPS.

CSSX has been well demonstrated for application at Savannah River (SR) and has been formally reviewed by DOE-SR. However, there are enough differences in the compositions between Hanford and SR waste that without testing with actual wastes on a laboratory scale and simulants at the pilot scale, a higher ranking on technical maturity could not be justified.

A rough order-of-magnitude estimate of the cost and schedule to mature the three technologies to a TRL of Level 6 (Definition 3.1.2) for the IPS application was also performed, in addition to an assessment of the probability of success (Definition 3.1.3). In all cases, facilities and equipment are available for laboratory and pilot testing, but given the recent testing of the pilot scale FC on Hanford SST salt cake feed simulants, it was deemed to have the least cost and most favorable schedule of the three technologies, with IX-sRF a close second. 
If the technical maturity cost and schedule estimates are considered in light of the overall project costs, the maturation costs would not be a discriminator (i.e., costs ranged from $\sim \$ 3 \mathrm{M}$ to $\sim \$ 4.5 \mathrm{M}$ ), nor would the 30 to 36 -month maturation schedule likely impact the IPS project critical path. A more detailed analysis of cost and schedule to mature the selected technologies will be documented in the upcoming IPS Technology Maturation Plan.

When considering the process flexibility and robustness measure, IX-sRF scored more favorably than either FC or CSSX overall. IX-sRF is considered to be able to handle greater variety of DST feeds (Definition 3.2.1), while FC ranked higher in turn up/turn down (Definition 3.2.2) and flexibility to modify the LAW product (Definition 3.2.3). CSSX was judged to be slightly less robust in this area, primarily due to uncertainty on ability to handle feed variability and ability to expand, if needed, post construction (Definition 3.2.4). No discrimination could be made among the cesium separation technologies with respect to recovery from out-of-specification product (Definition 3.2.5).

The rankings for the three technologies using this criterion were 9, 9, and 7 for FC, IX, and CSSX, respectively. Development work remains to ensure that the selected technology can process the candidate IPS feed vectors, e.g., issues such as phosphate solids for FC and Al solubility for IX-sRF and CSSX, albeit to a lesser extent with IX$\mathrm{sRF}$, due to the previous demonstration on real DST waste. 
RPP-RPT-38057, Rev. 0

A comparison of the technical aspects of respective technologies is provided in Table 3-6

Table 3-6 - Comparison of Technical Aspects for Cesium Separation

\begin{tabular}{|c|c|c|c|}
\hline $\begin{array}{l}\text { Technical } \\
\text { Pros \& Cons }\end{array}$ & $\mathrm{FC}$ & CSSX & IX-sRF \\
\hline Pros & $\begin{array}{l}\text { Has been } \\
\text { demonstrated on } \\
\text { SST simulants in a } \\
1 / 5 \text { scale pilot } \\
\text { Removes Te from } \\
\text { feed to WTP LAW }\end{array}$ & $\begin{array}{l}\text { Demonstrated at } \\
\text { SRS and has a pilot } \\
\text { scale facility } \\
\text { available for further } \\
\text { demonstration and } \\
\text { testing }\end{array}$ & $\begin{array}{l}\text { Well developed } \\
\text { technology used } \\
\text { previously at } \\
\text { Hanford } \\
\text { Has been tested on } \\
\text { DST feeds } \\
\text { Would provide a } \\
\text { hot pilot to WTP } \\
\text { pretreatment } \\
\end{array}$ \\
\hline Cons & $\begin{array}{l}\text { Requires testing on } \\
\text { DST feeds } \\
\text { Sensitive to sulfate } \\
\text { and phosphate } \\
\text { content in feed } \\
\text { Na recovery for } \\
\text { DST feeds averages } \\
40-45 \% \\
\text { Requires feed from } \\
16 \text { tanks to provide } \\
\text { feed for } 5 \text { year } \\
\text { mission ( } 3+\text { full } \\
\text { tank to tank } \\
\text { transfers a year) }\end{array}$ & $\begin{array}{l}\text { Requires testing on } \\
\text { DST feeds } \\
\text { Process sensitive to } \\
\text { potassium content } \\
\text { in the feed } \\
\text { Based on } \\
\text { conservative Al } \\
\text { solubility model, } \\
\text { requires significant } \\
\text { addition of cold } \\
\text { NaOH to process }\end{array}$ & $\begin{array}{l}\text { Based on } \\
\text { conservative } \mathrm{Al} \\
\text { solubility model, } \\
\text { requires significant } \\
\text { addition of cold } \\
\mathrm{NaOH} \text { to process }\end{array}$ \\
\hline
\end{tabular}

\subsubsection{Operability/Maintainability}

The Operability and Maintainability criterion was divided into 6 Measures - ease of process control (further evaluated by 10 definitions), ALARA, reliability ( 2 definitions), ease and frequency of maintenance ( 5 definitions), ease of implementation ( 3 definitions), and liquid/solid secondary waste ( 2 definitions).

In five of the 6 Measures under this Criterion (process control, ALARA, reliability, maintenance, and implementation) IX-sRF scored the highest, followed by FC. In the sixth measure (secondary waste) FC scored the best, primarily because of the periodic need to dispose of spent solvent and resin for the CSSX and IX-sRF processes, respectively. No discrimination could be made between the cesium separation technologies with respect to operating crew size (Definition 4.1.2), complexity of transfers between Tank Farms and IPS (Definition 4.1.10), or reliability of analogous systems (Definition 4.3.2). 
The rankings in this criterion for the three technologies were 8,8 , and 6 for IX, FC, and CSSX, respectively. All of the technologies would benefit from optimization and most of the operability and maintainability concerns associated with any of the technologies would be addressed by working closely with operations staff during the design phase of the project.

\subsubsection{Programmatic Aspects}

The Programmatic Aspects criterion was divided into 6 Measures - cost impact (further evaluated by 3 Definitions), schedule impact (4 Definitions), DST space (2 Definitions), impacts to WTP/STP (8 Definitions), impacts to other facilities (4 Definitions), and resources and materials (2 Definitions).

The rankings in this criterion for the three technologies were 11,11 , and 8 for IX, FC, and CSSX, respectively.

No distinction could be made between the cesium separation technologies with respect to the permitting, licensing, and D\&D schedules (Definitions 5.2.2, 5.2.3, and 5.2.4), overall WTP production rate (Definition 5.4.1) or mission duration (Definition 5.4.2), WTP waste packages (Definition 5.4.3), impacts to other Hanford facilities (Measure 5.5), or stability of critical resource pricing (Definition 5.6.2).

With respect to cost and schedule impacts (Measures 5.1 and 5.2), IX-sRF scored the best, followed by FC and CSSX, based on no consideration of the additional incremental implementation costs required to supply additional feed to FC. Detail on the cost and schedule estimates can be found in Attachment C.

With respect to DST space generation (Measure 5.3), the initial assessment shows FC generates space faster due to the higher processing rates associated with its operation and the amount of feed from each DST that is returned to the Tank Farms due to its lower Na recovery rate. Additionally, both the IX and CSSX process flowsheets used a very conservative aluminum (A1) solubility model that had a net effect of slowing the process rate and thus, decreasing the rate that is DST space generated. The estimated amount of space gained by FC ranges from 6.4 to $2.8 \mathrm{Mgal}$, depending on whether the waste is assumed to be transferred to Tank Farms as generated at $9 \mathrm{M} \mathrm{Na}$, or whether it is limited to $0.1 \mathrm{M}$ phosphate, respectively. The $0.1 \mathrm{M}$ phosphate limit triggers boil down evaluations to ensure that phosphate solids formation does not occur as a result of concentrated waste. In comparison, the estimated amount of space gained by IX is 3.7 $\mathrm{Mgal}$ and CSSX is $2.6 \mathrm{Mgal}$ (with the potential to increase to $3.6 \mathrm{Mgal}$ if concentrated to $0.8 \mathrm{Ci} \mathrm{Cs}$ in the 242-A Evaporator). Since there was significant uncertainty of the

phosphate impact and the impact is a function of the feed tanks chosen, FC was favorably credited with about $4.5 \mathrm{Mgal}$ of space gained over the 5 year mission by the Board. 
Further discussion of the DST space recovered occurred later in the Board deliberations. As stated above, FC was favorably credited with $4.5 \mathrm{Mgal}$ of DST space recovered over the 5 year period, by neglecting the impact from processing the high phosphate SST wastes in Year 5 (coincidentally, it is also approximately the average between the maximum value of $6.4 \mathrm{Mgal}$ and the minimum estimate of $2.8 \mathrm{Mgal}$ ). Conversely, the worst case volume of DST space recovered was used for both IX-sRF and CSSX. The Board determined that further discussion of the technical issues and uncertainties for all technologies in order to maximize the DST space recovered for the amount of waste processed was warranted.

Figure 3-1 - Comparison of Net Change in Available DST Waste Storage Space For Alternative Cesium Separation Technologies

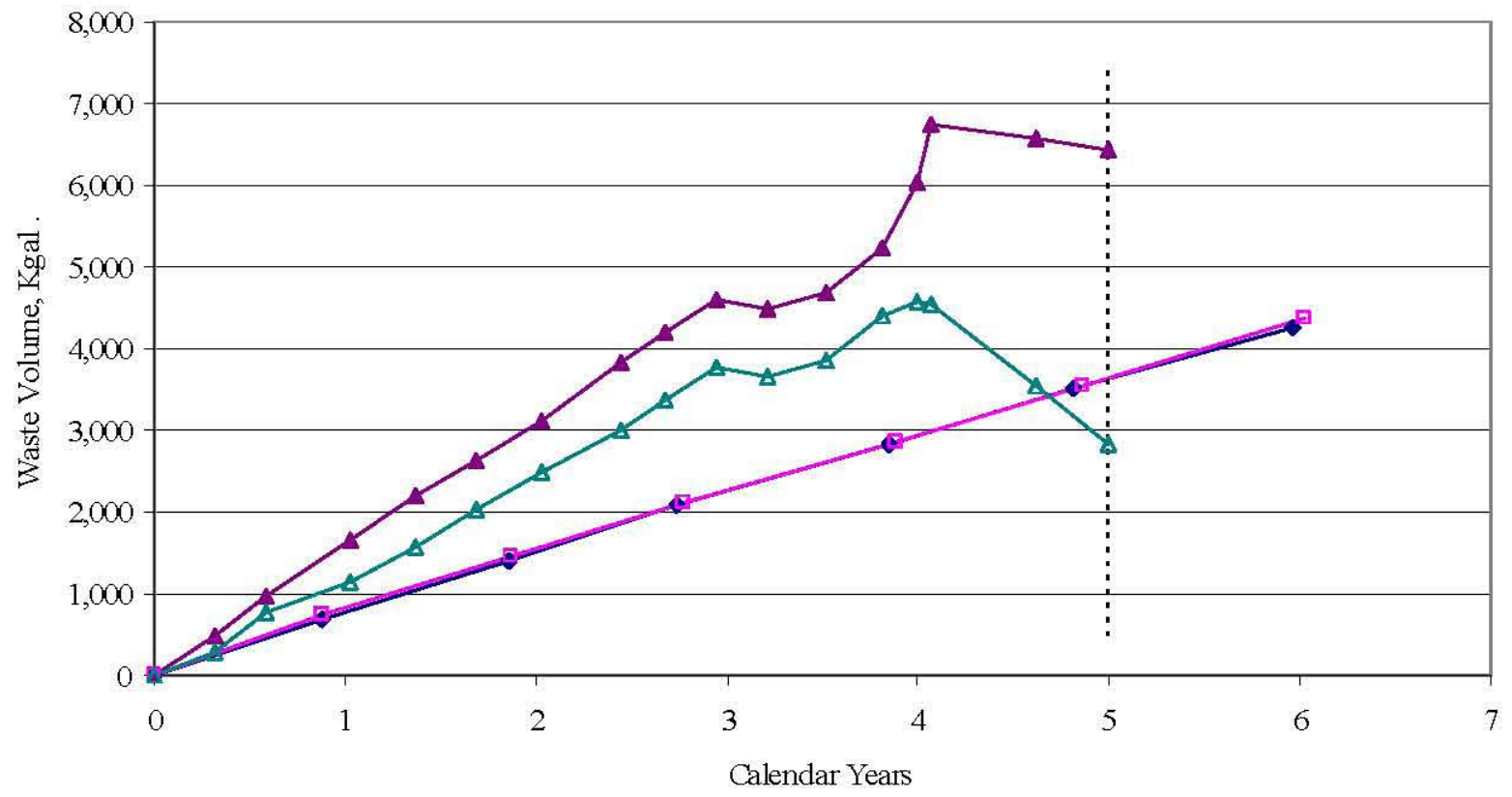

$\longrightarrow$ Ion Exchange, as generated
$\longrightarrow$ - Fractional Cyystallization, Generated at $9 \mathrm{MNa} \rightarrow$ Fractional Crystallization, max of $0.1 \mathrm{M}$ PO4

FC would have to process $14.9 \mathrm{Mgal}$ of feed from 16 feed tanks in order to meet the WTP/supplemental treatment requirement of $5875 \mathrm{MT} \mathrm{Na}$ for the 5 year mission. Because of the amount of waste returned to the Tank Farms (i.e., 57\% of the $\mathrm{Na}$ is returned in the Cs return stream), the estimated amount of space recovered from processing the $14.9 \mathrm{Mgal}$ of feed through $\mathrm{FC}$ ranges from 6.4 to $2.8 \mathrm{Mgal}$, depending on whether the waste is assumed to be transferred to Tank Farms as generated at $9 \mathrm{M} \mathrm{Na}$, or whether it is limited to $0.1 \mathrm{M}$ phosphate, respectively. Because the concern with phosphate precipitation and the potential to plug waste transfer lines, the acceptable concentration of phosphates will need to be determined on a batch-by-batch basis, using the "boil down" procedure prior to its transfer from IPS to the DST system. As such, there is significant uncertainty regarding the amount of tank space that could be recovered. Further, if the results from the boil-down test are not favorable, an alternative 
would be a cost/benefit analysis of the addition of a phosphate removal step to IPS versus the additional tank space recovered.

In comparison, the worst case Al solubility model was applied during the development of both the IX-sRF and CSSX flowsheets. The DST feeds selected for this evaluation contain concentrated aluminum in solution. Neither IX-sRF nor CSSX are tolerant of solids precipitating with the process as the waste chemistry changes during processing. To protect the processes, both the CSSX and IX-sRF processes assumed that the $\mathrm{Na}$ molarity of the incoming waste feed must first be adjusted to $6 \mathrm{M}$ sodium, if the WTP solubility curves for aluminum are used. This adjustment requires the addition of $\sim 30 \%$ cold (non-radioactive waste) sodium. Based on the worst case model, the amount of space gained by IX-sRF is $3.7 \mathrm{Mgal}$ and CSSX is $2.6 \mathrm{Mgal}$ (with the potential to increase to $3.6 \mathrm{Mgal}$ if concentrated to $0.8 \mathrm{Ci} \mathrm{Cs}$ in the $242-\mathrm{A}$ Evaporator). If the Al solubility issue is resolved, the additional $\mathrm{NaOH}$ required by the process flowsheets evaluated for IX-sRF and CSSX would be greatly reduced. The impact would be to increase the amount of feed processed $9.1 \mathrm{Mgal}$ and would result in the recovery of $6.2 \mathrm{Mgal}$ of DST space for IX-sRF and up to $6 \mathrm{Mgal}$ of space for CSSX with the use of the 242-A Evaporator. Resolving the aluminum solubility issue also benefits the WTP by reducing the estimated Na processed from $90,000 \mathrm{MT}$ to $60,000 \mathrm{MT}$. Because of the significant impact of the Al solubility on waste volume, an EM-20 initiative is underway to update the Al solubility model.

For all the technologies, the maximum DST space recovered in the best case is estimated at between $6-6.4 \mathrm{Mgal}$, if the respective technical issues can be resolved. However, to put it in a different perspective, the DST space recovered is shown as a "return on investment" (i.e., space recovered for the amount of waste processed) in Figure 3-2 and Table 3-7. As an interesting note, IX-sRF has a 68\% "return" even under the worst case compared to range of $19 \%$ to $43 \%$ for $\mathrm{FC}$, and $48 \%$ to $67 \%$ for CSSX. 
RPP-RPT-38057, Rev. 0

Figure 3-2 - Comparison of DST Space Recovered For the Amount of Waste Processed

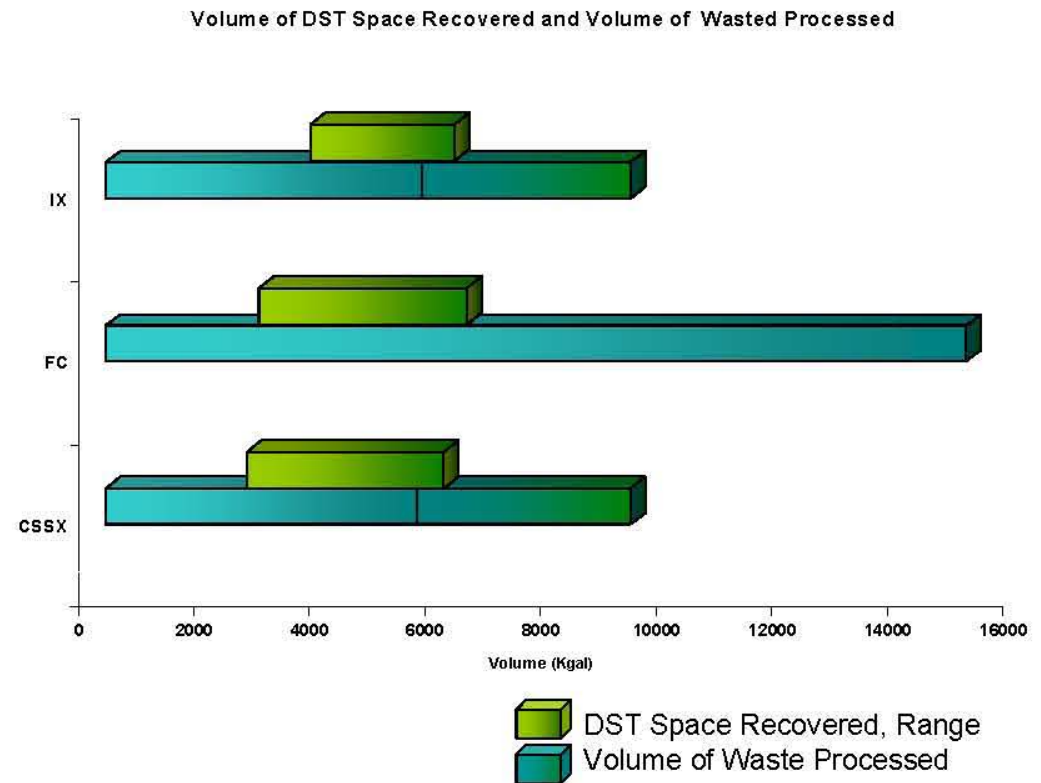

Table 3-7 - Project Feed Volume and DST Space Recovered Over 5 Year IPS Mission

\begin{tabular}{|l|c|c|c|c|c|c|}
\cline { 2 - 7 } \multicolumn{1}{c|}{} & \multicolumn{2}{c|}{$\begin{array}{c}\text { Fractional } \\
\text { Crystallization }\end{array}$} & \multicolumn{2}{c|}{ Ion Exchange } & \multicolumn{2}{c|}{$\begin{array}{c}\text { Caustic Side Solvent } \\
\text { Extraction }^{3}\end{array}$} \\
\cline { 2 - 7 } & $\begin{array}{l}\text { Worst } \\
\text { Case }\end{array}$ & Best Case & Worst Case & Best Case & Worst Case & Best Case \\
\hline $\begin{array}{l}\text { Feed Volume } \\
\text { Processed, Mgal }\end{array}$ & 14.9 & 14.9 & 5.5 & 9.1 & 5.4 & 9.1 \\
\hline $\begin{array}{l}\text { DST Space } \\
\text { Recovered, } \\
\text { Mgal }\end{array}$ & 2.8 & 6.4 & 3.7 & 6.2 & $2.6-3.6$ & $3.6-6.0$ \\
\hline $\begin{array}{l}\text { \% Return } \\
\text { (DST Space } \\
\text { recovered/ Feed } \\
\text { volume } \\
\text { processed) }\end{array}$ & $19 \%$ & $43 \%$ & $68 \%$ & $68 \%$ & $48-67 \%$ & $55-66 \%$ \\
\hline
\end{tabular}

\footnotetext{
${ }^{1}$ The comparison for Fractional Crystallization is based conservatively on whether phosphate is a factor (worst case) or the whether the waste is concentrated to $9 \mathrm{MNa}$ (best case).

${ }^{2}$ The comparison for Ion Exchange is based on the added $\mathrm{Na}$ (worst case) to address the conservative $\mathrm{Al}$ solubility curves or whether the more liberal (e.g., Barney solubility data [ARH-ST-133] is used (best case).

${ }^{3}$ The comparison for Caustic Side Solvent Extraction is based on the same worst case/best case Al assumptions shown for Ion Exchange, with a range provided to account for the space gained from concentrating the $\mathrm{Cs}$ return stream in $242-\mathrm{A}$ evaporator to $0.8 \mathrm{Ci} / \mathrm{L}$.
} 
Regarding impacts to WTP and Supplemental Treatment (Measure 5.4), IX-sRF and FC were ranked equally, followed by CSSX. FC would provide alternative evaporator capacity and a potential for using grout for immobilization of Tc-free LAW. IX-sRF provides potential cost reduction benefits by combining IPS and WTP IX technology deployment activities, as well as possible benefits for future Tc removal. Additionally, the WTP pretreatment process development, operation and maintenance would benefit from the lessons learned by deployment of IX-sRF in IPS. During the assessment, no ancillary programmatic benefits were identified for CSSX. Finally FC was rated higher than either IX-sRF or CSSX for availability of key skill, critical materials, and qualified vendors (Definition 5.6.1), due to the single vendor for CSSX centrifugal contactors and the current lack of a long-term supply strategy for the IX-sRF resin.

\subsubsection{Additional Assessment}

Because the results were so close between FC and IX-sRF, the Board determined that further evaluation was necessary in order to make the final recommendation for a cesium separation technology. The need for additional evaluation was anticipated in the Decision Plan (CH2M HILL 2008b0

\section{... Some additional work may be required prior to the final assignment of rating or the} selection of the preferred technology.

Mindful of the DOE goal of the IPS Project as articulated by the ORP Decision Maker, "Deliver five years of pretreated feed to the Waste Treatment Plant's Low-Activity Waste Vitrification facility as early as possible and for the least cost to the government, "the Board decided re-examine the implementation costs and implementation schedule aspects of the two technologies as the basis for making the final selection between the two technologies.

\subsubsection{Implementation Costs}

As noted in the discussion under the cost impacts, the incremental implementation costs, including baseline costs that would have to be accelerated into the mission period were not considered in the initial assessment by the Board. Because FC returns approximately $57 \%$ of the $\mathrm{Na}$ from the tank waste back to the Tank Farms with the Cs, a total of 16 feed tanks $(14.9 \mathrm{Mgal})$ is required in order to supply sufficient $\mathrm{Na}$ to meet the WTP/supplemental treatment annual requirement of $1175 \mathrm{MT} \mathrm{Na} /$ year over the 5 year mission. Based on the tanks chosen by the FC SME (and discussions with technical staff knowledgeable about $\mathrm{Na}$ loading and tank composition) to supplement the initially identified feed candidate DSTs, this requires an incremental 16 tank to tank transfers, 2 SST retrievals and 3 cross-site transfers above and beyond the tank to tank transfers required for either IX-sRF or CSSX, increasing the life cycle costs for FC by an estimated $\$ 50-60 \mathrm{M}$ during the mission period. This is shown in the cost ranges labeled $F C / C F F w / T \& R$ and $F C / R M F w / T \& R$ in Figure 3-3. 
While an argument was considered that retrievals would have to be done eventually, would only be moved forward in time and/or substituted for other planned retrievals that would be ongoing during this mission period, ORP-11242, River Protection Project System Plan, (ORP 2008a) shows that no SST retrievals are planned or funded for the mission period. Further, while optimization of the feed tanks selected for FC could have reduced these costs somewhat, to allow such 'cherry-picking' of the feed tanks that would be best suited for FC would potentially have unfairly biased the evaluation, unless an equal feed optimization endeavor was undertaken for IX-sRF and CSSX.

\section{Figure 3-3 - Life-Cycle Cost Estimate Summary (for comparative purposes only)}

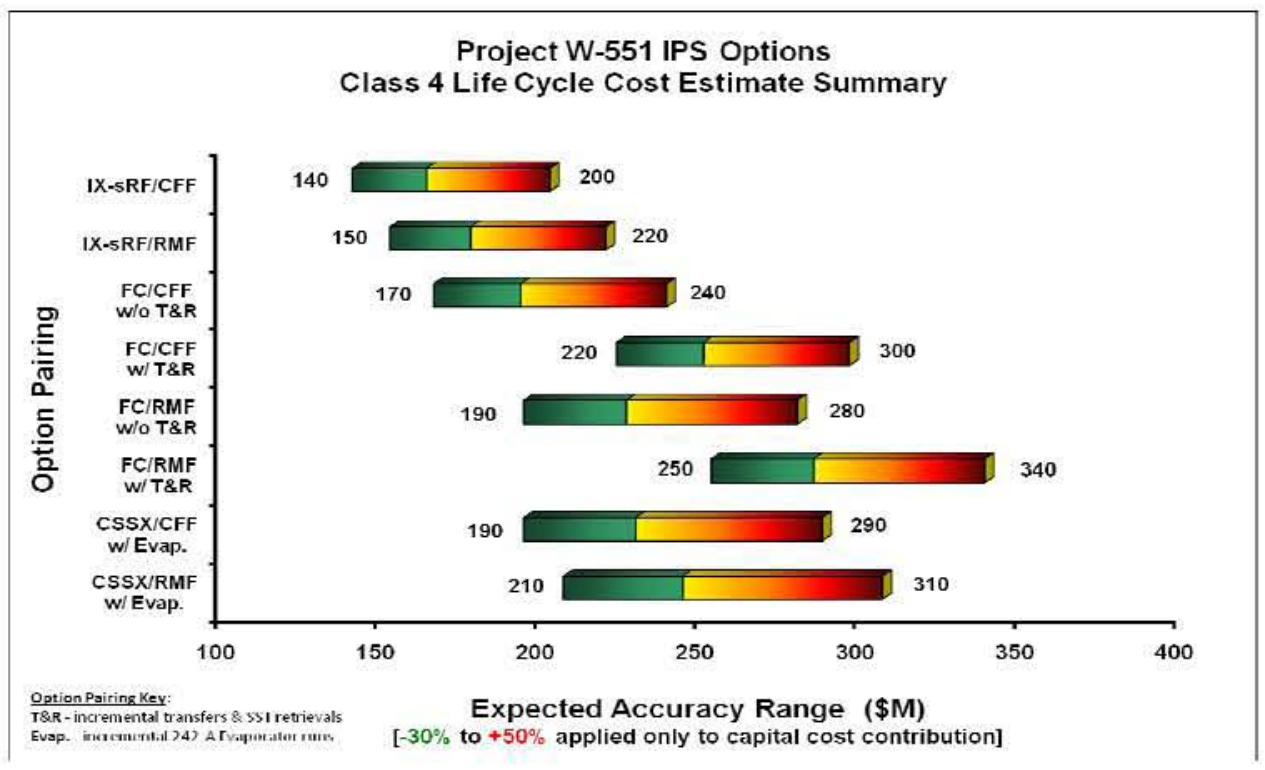

While IX-sRF did receive the highest ranking in the initial evaluation, consideration of these additional incremental implementation costs led the Board to conclude that IX-sRF is clearly the more cost effective choice. 


\subsubsection{Implementation Schedules}

The initial schedule assessment did show that IX-sRF had the best implementation schedule of the three cesium technologies. Further review and discussion between the Board and knowledgeable project management staff upheld the determination that the deployment of IX-sRF technology also represented the least schedule risk to IPS project.

\section{Figure 3-4 - Implementation Schedule Duration Comparison}

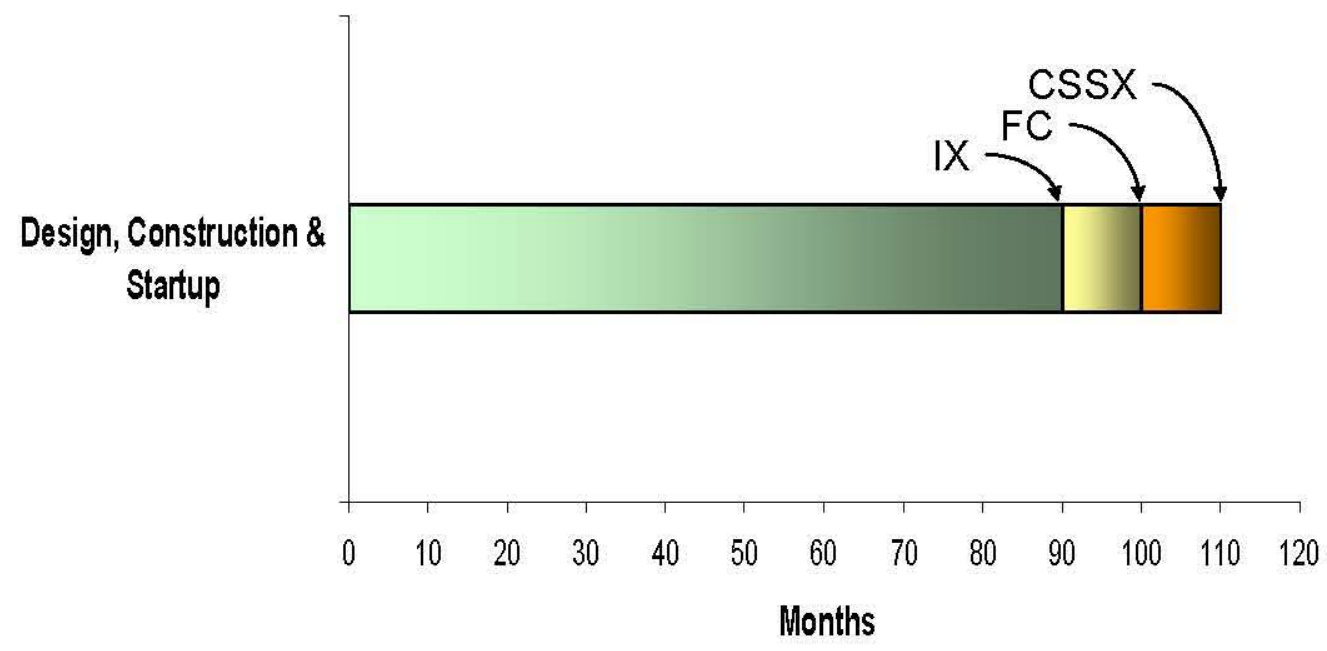

Estimated duration from date of authorization to proceed

[Schedule estimates are for comparative purposes between the technologies only \& DO NOT reflect the total IPS project schedule]

\subsubsection{Conclusion - Cesium Separation}

In summary, while by FC and IX-sRF are both viable technologies for cesium separation, the further examination of FC and IX-sRF with respect to the incremental implementation costs, including baseline costs that would have to be accelerated into the mission period, and implementation schedule duration and risk clearly favors IX-sRF:

- Implementation costs for IX-sRF are estimated at \$80M less than FC, and

- The earliest possible deployment of IPS could be achieved with the IX-sRF technology. 


\subsection{EXPERT REVIEW PANEL}

The Expert Review Panel (ERP) assessed the technology selection process in early July 2008 as part of its scope. Based on the initial draft of this summary report, the ERP concluded that sufficient technical information was available to make a selection and that an objection multi-attribute decision process had been used to make the technology selection. The ERP had a number of observations and suggestions to clarify the documentation of the technology selection process.

Several elements of the selection process were closely examined by the ERP, including the tight clustering of the raw ranking scores around 5, the assignment of the weights for the all elements under selection criteria and inclusion of safety related elements within other criterion besides safety (the ERP suggestion was to bin all Safety elements under a single Safety Criterion). During the July 2008 meetings, as an exercise, the ERP performed an abbreviated assessment of the cesium separation technologies with adjustments to the elements noted above. While the ERP's weighted scores for the three technologies were more widely spread, the conclusion was the same - IX-sRF is the preferable technology for cesium separation (See Table 4-1).

Table 4-1 - Comparison of Decision Board versus ERP Cs Separation Evaluation Weighted Results

\begin{tabular}{|l|c|c|c|c|c|c|}
\hline \multirow{2}{*}{ Criteria } & \multicolumn{3}{|c|}{ Original Decision } & \multicolumn{2}{c|}{ Expert Review Panel } \\
\cline { 2 - 7 } & FC & CSSX & $\begin{array}{c}\text { IX- } \\
\text { sRF }\end{array}$ & FC & CSSX & $\begin{array}{c}\text { IX- } \\
\text { SRF }\end{array}$ \\
\hline Safety & 13 & 11 & 11 & 20 & 7 & 13 \\
\hline $\begin{array}{l}\text { Regulatory \& } \\
\text { Stakeholder } \\
\text { Acceptance }\end{array}$ & 11 & 9 & 11 & 12 & 8 & 13 \\
\hline $\begin{array}{l}\text { Technical } \\
\text { Maturity/Flexibility }\end{array}$ & 9 & 7 & 9 & 12 & 5 & 15 \\
\hline $\begin{array}{l}\text { Operability and } \\
\text { Maintainability }\end{array}$ & 8 & 6 & 8 & 11 & 3 & 12 \\
\hline $\begin{array}{l}\text { Programmatic } \\
\text { Aspects }\end{array}$ & 11 & 8 & 11 & 11 & 8 & 15 \\
\hline Total & $\mathbf{5 1}$ & $\mathbf{4 1}$ & $\mathbf{5 0}$ & $\mathbf{6 5}$ & $\mathbf{3 2}$ & $\mathbf{6 8}$ \\
\hline
\end{tabular}




\subsection{RECOMMENDATIONS}

After the additional review of the implementation costs and schedule for the cesium separation technologies, the Board made the following unanimous recommendations:

- Proceed with project effort to construct and start up a new interim pretreatment system in the Hanford tank farms comprised of cross-flow filtration for entrained solids removal, and ion exchange for cesium separation, using spherical resorcinol-formaldehyde resin.

- Continue limited testing of fractional crystallization to ensure an alternate cesium removal technology for reducing the risk of cost-effectively providing a waste feed supply to the Waste Treatment Plant. Testing scope shall be defined in the follow-up Technical Maturation Plan.

The recommendation of CFF over RM was based on two considerations: 1) that construction and installation of the CFF units will be performed in non-radioactive conditions (green field), while RMF would require modification of an existing DST pit and installation within a nuclear facility; and 2) that there is a high likelihood the RMF units will need to be replaced during the 5-year IPS mission.

The recommendation of IX-sRF over CSSX and FC was based on the consideration that the earliest possible deployment of IPS could be achieved with the IX-sRF technology. Implementation schedules showed that IPS could be implemented approximately one year earlier if the IX-sRF technology was selected over FC and approximately two years earlier if IX-sRF was selected over CSSX. Additionally, the IX-sRF capital and life cycle costs were estimated to be significantly lower than the other two technologies and represent the best "return" on recovered DST space.

As an ancillary benefit, selection of CFF and IX-sRF as the recommended technologies provides potential cost reduction benefits by combining IPS and Waste Treatment Plant (WTP) technology deployment activities. Additionally, the WTP pretreatment process development, operation and maintenance would benefit from the lessons learned by deployment of CCF and IX in IPS. 


\subsection{REFERENCES}

CH2M HILL 2008a, External Letter D.B. Cartmell to C.B. Reid, Technical Scope Statement for the Interim Pretreatment System Project, CH2M-0800043 R1, February 28, 2008,

CH2M HILL 2008b, May, T. H. et al, Decision Plan: Selection of Early LAW Interim Pretreatment System Processes for Removal of Entrained Solids and Cesium, Rev. 0, RPP-PLAN-37558, May 5, 2008, CH2M HILL Hanford Group Inc., Richland, Washington.

CH2M HILL 2008c, May, T. H. et al, Project $W$-551 Interim Pretreatment System PreConceptual Candidates Technology Descriptions, Rev. 0, RPP-RPT-37551, June 12, 2008, CH2M HILL Hanford Group Inc., Richland, Washington.

CH2M HILL 2008d, Tedeschi, A. R. et al, Project $W$-551 Determination Data for Early LAW Interim Pretreatment System Selection, Rev. 0, RPP-RPT-37741, July 2008, CH2M HILL Hanford Group Inc., Richland, Washington.

CH2M HILL 2008e, Tedeschi, A. R. et al, Project W-551 Summary Information for Early LAW Pretreatment System Selection, Rev 0, RPP-RPT-37740, July 2008, CH2M HILL Hanford Group Inc., Richland, WA.

CH2M HILL 2008f, Tedeschi, A. R., IPS Decision Calculation Rev 1 with Workshop Data 6-18-08.xls, Rev 0, SVF-1520, June 2008, CH2M HILL Hanford Group Inc., Richland, WA.

ORP 2008a, External Letter, C.B. Reid to D.B. Cartmell, Initiation Mission Analysis and Preliminary Conceptual Design for Interim Pretreatment System (IPS), 08-AMD050, March 10, 2008.

ORP 2008b, Certa, P. J., River Protection Project System Plan, Rev. 3, ORP-11242, May 2008, U. S. Department of Energy, Office of River Protection, Richland, Washington. 


\section{ATTACHMENT A. SOLIDS FILTRATION TECHNOLOGY DECISION SUPPORT BOARD ASSESSMENT}

Table A-1 - Solids Filtration Technology Assessment Matrix Summary

\begin{tabular}{|c|c|c|c|}
\hline Criteria & Measures and Definitions & Cross-flow Filtration (CFF) & Rotary Micro-filtration (RMF) \\
\hline \multirow[t]{6}{*}{$\begin{array}{l}1 \text { SAFETY } \\
1.1 \text { Process Safety }\end{array}$} & $\begin{array}{l}\text { 1.1.1 Quantity of material at risk } \\
\text { (MAR) - radiological and } \\
\text { chemical - less is better }\end{array}$ & $\begin{array}{l}\text { - The CFF system does have a larger hold up } \\
\text { (volume) then the RMFs. The quantity waste in } \\
\text { the system is several thousand gallons. An } \\
\text { individual flush of the CFF system also would use } \\
\text { a larger volume of chemical. This technology } \\
\text { therefore has a higher quantity of MAR. }\end{array}$ & $\begin{array}{l}\text { Each RMF unit has a hold up of about } 40 \text { gallons } \\
\text { or about } 160 \text { gallons total for the CSSX and IX- } \\
\text { sRF options ( } 4 \text { RMF units) and about } 500 \text { gallons } \\
\text { total ( } 12 \text { RMF units) for the FC option. Each } \\
\text { RMF unit has less MAR then the CFF unit. }\end{array}$ \\
\hline & $\begin{array}{l}\text { 1.1.2 } \text { Concentration of } \\
\text { radiological and chemical } \\
\text { MAR - less is better }\end{array}$ & $\begin{array}{l}\text { - Since the feed vector does not have a solids } \\
\text { component there is no change in the concentration } \\
\text { of radiological and chemical MAR. The solids in } \\
\text { the } 8 \text { feed tanks have a MAR similar to the liquid. } \\
\text { While the MAR could change with a different } \\
\text { feed, any changes would be similar for both CFF } \\
\text { and RMF }\end{array}$ & $\begin{array}{l}\text { - Since the feed vector does not have a solids } \\
\text { component there is no change in the concentration } \\
\text { of radiological and chemical MAR. The solids in } \\
\text { the } 8 \text { feed tanks have a MAR similar to the liquid. } \\
\text { While the MAR could change with a different } \\
\text { feed, any changes would be similar for both CFF } \\
\text { and RMF }\end{array}$ \\
\hline & 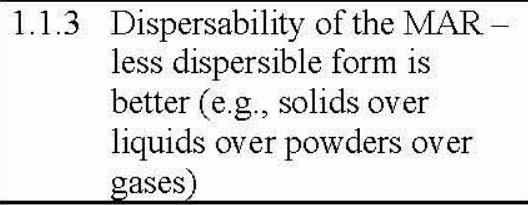 & - The MAR is a liquid with entrained solids. & - The MAR is a liquid with entrained solids. \\
\hline & $\begin{array}{l}\text { 1.1.4 Dispersive energy, e.g., heat, } \\
\text { off gassing, pressure, etc. } \\
\text { inherent in the process - less } \\
\text { dispersive energy is better }\end{array}$ & $\begin{array}{l}\text { CFF uses a high capacity recirculation pump } \\
\text { (1,100-3,300 gpm). In the event of a recirculation } \\
\text { pump component failure (e.g. large pipe break } \\
\text { accident), dispersive energy would be significant } \\
\text { due to the high supply flow rate. }\end{array}$ & $\begin{array}{l}\text { RMF system has significantly lower flow rates } \\
\text { then CFF. However, the rotational energy of the } \\
\text { spinning disks will have to be evaluated as part of } \\
\text { a housing failure accident. }\end{array}$ \\
\hline & $\begin{array}{ll}1.1 .5 & \text { Process Stability - including } \\
\text { ease of process } \\
\text { control/shutdown -- } \\
\text { easier/faster process } \\
\text { shutdown is better }\end{array}$ & $\begin{array}{l}\text { Quick shutdown can be achieved by shutting of } \\
\text { the system pumps. }\end{array}$ & $\begin{array}{l}\text { - Quick shutdown can be achieved by shutting of } \\
\text { the pumps and filter motors. }\end{array}$ \\
\hline & $\begin{array}{l}\text { 1.1.6 Process that does not create } \\
\text { a new or exacerbate an } \\
\text { existing Tank Farm hazard is } \\
\text { preferred to one that does }\end{array}$ & $\begin{array}{l}\text { Potential exists for one tank farm hazard } \\
\text { accidental scenario - mixing of incompatible } \\
\text { chemicals. }\end{array}$ & $\begin{array}{l}\text { Potential exists for one tank farm hazard } \\
\text { accidental scenario - mixing of incompatible } \\
\text { chemicals. }\end{array}$ \\
\hline
\end{tabular}


Table A-1 - Solids Filtration Technology Assessment Matrix Summary

\begin{tabular}{|c|c|c|c|}
\hline Criteria & Measures and Definitions & Cross-flow Filtration (CFF) & Rotary Micro-filtration (RMF) \\
\hline & $\begin{array}{l}\text { 1.1.7 Less fire hazard (e.g. less } \\
\text { quantity of combustibles, } \\
\text { including flammable gas, } \\
\text { less flammable } \\
\text { combustibles, etc.) }\end{array}$ & $\begin{array}{l}\text { The CFF will have to be evaluated for flammable } \\
\text { gas retention and release due to solids in the } \\
\text { system during shutdown and start up. The solids } \\
\text { hold up is larger in the CFF system. }\end{array}$ & $\begin{array}{l}\text { The RMF will have to be evaluated for flammable } \\
\text { gas retention and release due to solids in the } \\
\text { system during shutdown and start up. The solids } \\
\text { hold up is larger in the CFF system. }\end{array}$ \\
\hline & $\begin{array}{l}\text { 1.1.8 Reactive Chemicals - } \\
\text { Process with less reactive } \\
\text { chemicals (reactivity) is } \\
\text { better }\end{array}$ & $\begin{array}{l}\text { - Caustic and nitric acid wash solutions are used for } \\
\text { filter cleaning. These would have to be } \\
\text { /treated/neutralized in the CFF system to meet } \\
\text { DST specifications. }\end{array}$ & $\begin{array}{l}\text { - Caustic and nitric acid wash solutions are used for } \\
\text { filter cleaning. Since nitric acid potentially will } \\
\text { be used for cleaning and since in two } \\
\text { configurations the RMFs are in the DST, further } \\
\text { evaluation and changes to the TF DSA may be } \\
\text { required }\end{array}$ \\
\hline 1.2 Criticality Safety & $\begin{array}{l}\text { 1.2.1 A Process that is inherently } \\
\text { sub-critical is preferred over } \\
\text { a process that relies on } \\
\text { criticality controls }\end{array}$ & $\begin{array}{l}\text { - CFF process is sub-critical under expected } \\
\text { conditions as it does not hold up enough volume } \\
\text { to approach the critical mass limit with the } \\
\text { projected feed vector. A review of BBI data for } \\
\text { the source tanks also shows that even if sludge } \\
\text { was transferred the above statement is still true. } \\
\text { - Criticality is not credible because the fissile } \\
\text { material concentration will always remain too low } \\
\text { and the neutron absorbers are too abundant. } \\
\text { CFF does not change the result of tank farm DSA } \\
\text { evaluation. }\end{array}$ & $\begin{array}{l}\text { RMF process is sub-critical under expected } \\
\text { conditions as it does not hold up enough volume } \\
\text { to approach the critical mass limit with the } \\
\text { projected feed vector A review of BBI data for } \\
\text { the source tanks also shows that even if sludge } \\
\text { was transferred the above statement is still true. } \\
\text { Criticality is not credible because the fissile } \\
\text { material concentration will always remain too low } \\
\text { and the neutron absorbers are too abundant. } \\
\text { RMF does not change the result of tank farm } \\
\text { DSA evaluation. }\end{array}$ \\
\hline $\begin{array}{l}\text { 1.3 Industrial Safety and } \\
\text { Hygiene }\end{array}$ & $\begin{array}{l}\text { 1.3.1 Less hazards/less severe } \\
\text { hazardous is better (e.g., less } \\
\text { hazardous chemicals, less } \\
\text { noise, less hot surfaces, less } \\
\text { rotating equipment, less } \\
\text { confined spaces, etc.) }\end{array}$ & $\begin{array}{l}\text { - Located in a below grade area within the IPS } \\
\text { facility, considered to be a confined space in } \\
\text { radiation zone. } \\
\text { - Low shear high capacity circulation pump may } \\
\text { have some noise hazards with routine } \\
\text { maintenance requirements. } \\
\text { - Does not use hazardous (severe) chemicals. }\end{array}$ & $\begin{array}{l}\text { - RMF equipment mounted at grade on an existing } \\
\text { DST riser and a vault for the FC option. } \\
\text { - Uses rotating disks (with adjustable speed) in a } \\
\text { pressurized module. } \\
\text { - Modular design approach for filter pack. } \\
\text { - Minimal noise hazards. } \\
\text { - Does not use hazardous (severe) chemicals. }\end{array}$ \\
\hline $\begin{array}{l}2 \text { REGULATORY/ } \\
\text { STAKEHOLDER } \\
\text { ACCEPTANCE } \\
2.1 \text { Achieve Tribal } \\
\text { Nations/ } \\
\text { stakeholders' } \\
\text { acceptance }\end{array}$ & $\begin{array}{l}\text { 2.1.1 Early waste treatment } \\
\text { enabled }\end{array}$ & $\begin{array}{l}\text { Early waste pretreatment schedule can be met. } \\
\text { Technological maturity assessment is needed to } \\
\text { confirm this. } \\
\text { - Can be permitted in } 28-33 \text { months with some } \\
\text { additional process demonstration work. }\end{array}$ & $\begin{array}{l}\text { - Early waste pretreatment schedule can be met. } \\
\text { Technological maturity assessment is needed to } \\
\text { confirm this. } \\
\text { - Can be permitted in } 28-33 \text { months with some } \\
\text { additional process demonstration work. } \\
\text { - RMF system requires a re-design to fit into a } 42 \text { - } \\
\text { inch diameter DST riser. }\end{array}$ \\
\hline
\end{tabular}


Table A-1 - Solids Filtration Technology Assessment Matrix Summary

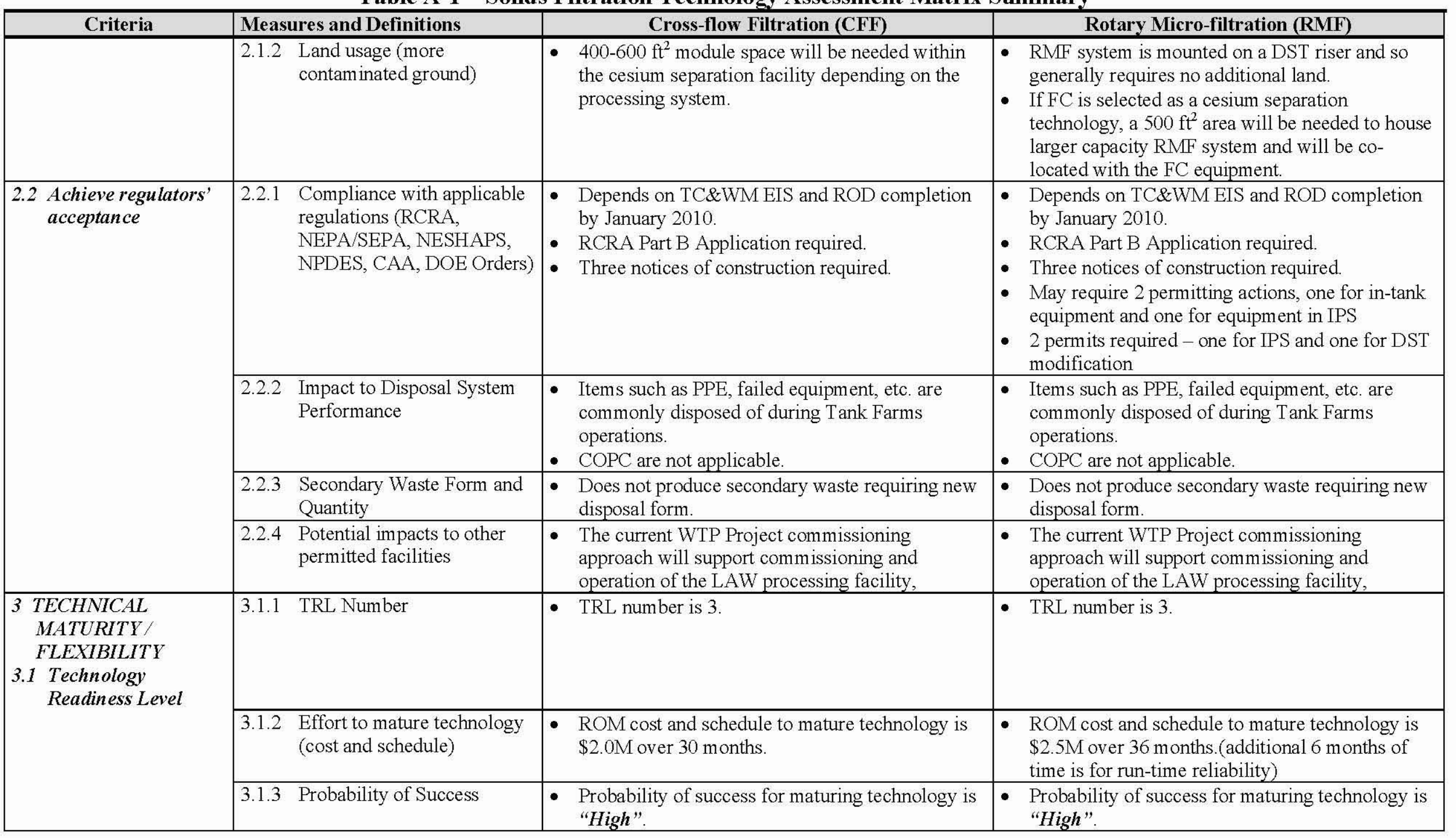


Table A-1 - Solids Filtration Technology Assessment Matrix Summary

\begin{tabular}{|c|c|c|c|}
\hline Criteria & Measures and Definitions & Cross-flow Filtration (CFF) & Rotary Micro-filtration (RMF) \\
\hline \multirow[t]{6}{*}{$\begin{array}{l}3.2 \text { Process Flexibility } \\
\text { and robustness }\end{array}$} & $\begin{array}{ll}3.2 .1 & \begin{array}{l}\text { Ability to process a variety } \\
\text { of feeds }\end{array} \\
\end{array}$ & $\begin{array}{l}\text { Demonstrates "Medium" level of flexibility to } \\
\text { process variety of Hanford tank waste feeds. }\end{array}$ & $\begin{array}{l}\text { - Demonstrates "High" level of flexibility to } \\
\text { process variety of Hanford tank waste feeds. }\end{array}$ \\
\hline & $\begin{array}{l}\text { 3.2.2 Ability to adjust process rate } \\
\text { (turn up/turn down) }\end{array}$ & $\begin{array}{l}\text { - Demonstrates "High" level of flexibility to adjust } \\
\text { process rates. } \\
\text { - Rated slightly lower because only pump rate can } \\
\text { be adjusted }\end{array}$ & $\begin{array}{l}\text { - Demonstrates "High" level of flexibility to adjust } \\
\text { process rates. } \\
\text { - Rated slightly higher because rotational speed can } \\
\text { also be adjusted }\end{array}$ \\
\hline & 3.2.3 Flexibility to modify product & $\begin{array}{l}\text { "Medium" filtration product flexibility with } 9 \\
\text { degrees of freedom. }\end{array}$ & $\begin{array}{l}\text { - "Medium" filtration product flexibility with } 10 \\
\text { degrees of freedom. }\end{array}$ \\
\hline & 3.2.4 Ability to expand & $\begin{array}{l}\text { Sized to meet required throughput for IPS } \\
\text { mission }\end{array}$ & $\begin{array}{l}\text { - Sized to meet required throughput for IPS } \\
\text { mission }\end{array}$ \\
\hline & $\begin{array}{ll}.2 .5 & \text { Recover from out of spec } \\
\text { product }\end{array}$ & $\begin{array}{l}\text { - "Medium" flexibility to recover from out of } \\
\text { specification product. }\end{array}$ & $\begin{array}{l}\text { - "Low" flexibility to recover from out of } \\
\text { specification product. }\end{array}$ \\
\hline & $\begin{array}{ll}3.2 .6 & \text { Technology applicability to } \\
& \text { other DOE complex projects }\end{array}$ & $\begin{array}{l}\text { - "High" applicability to other DOE complex } \\
\text { projects. }\end{array}$ & $\begin{array}{l}\text { - "Medium" applicability to other DOE complex } \\
\text { projects. }\end{array}$ \\
\hline \multirow[t]{5}{*}{$\begin{array}{l}4 \text { OPERABILITY \& } \\
\text { MAINTAINABILITY } \\
4.1 \text { Ease of Process } \\
\text { control and } \\
\text { operation }\end{array}$} & $\begin{array}{ll}4.1 .1 & \text { Minimize number and } \\
& \text { frequency of surveillances }\end{array}$ & $\begin{array}{l}\text { At least } 22 \text { process parameters are to be } \\
\text { monitored and it is comparable to current waste } \\
\text { transfer operation. }\end{array}$ & $\begin{array}{l}\text { With CSSX and IX-sRF, at least } 35 \text { process } \\
\text { parameters are to be monitored and it is } \\
\text { comparable to current waste transfer operation. } \\
\text { With FC, a total of } 71 \text { process parameters are to } \\
\text { be monitored due to increased number of filter } \\
\text { modules. }\end{array}$ \\
\hline & $\begin{array}{ll}4.1 .2 & \text { Minimize number of people } \\
\text { to operate }\end{array}$ & - Operation requires at least six people. & $\begin{array}{l}\text { Operation requires at least five people for CSSX } \\
\text { and IX-sRF and six when used with the FC. }\end{array}$ \\
\hline & $\begin{array}{ll}4.1 .3 & \begin{array}{l}\text { Ease of startup and } \\
\text { shutdown }\end{array}\end{array}$ & $\begin{array}{l}\text { Easy to startup and shutdown based on a small } \\
\text { number of moving components (2) and a } \\
\text { simplified process. }\end{array}$ & $\begin{array}{l}\text { Easy to startup and shutdown based on few (6) } \\
\text { moving components when used with CSSX and } \\
\text { IX-sRF. } \\
\text { - More complex due to higher number of moving } \\
\text { components (14) and multiple locations when } \\
\text { used with FC. }\end{array}$ \\
\hline & 4.1.4 Minimize system complexity & $\begin{array}{l}\text { - No more complex than any of the existing waste } \\
\text { transfer systems currently used in the tank farms. }\end{array}$ & $\begin{array}{l}\text { - No more complex than any of the existing waste } \\
\text { transfer systems currently used in the tank farms. }\end{array}$ \\
\hline & $\begin{array}{l}\text { 4.1.5 Minimize number of } \\
\text { chemicals needed }\end{array}$ & $\begin{array}{l}\text { Process uses modest quantities of basic } \\
\text { chemicals, sodium hydroxide and nitric acid for } \\
\text { filter flush. }\end{array}$ & $\begin{array}{l}\text { Process uses modest quantities of basic } \\
\text { chemicals, sodium hydroxide and nitric acid for } \\
\text { filter flush. }\end{array}$ \\
\hline
\end{tabular}


Table A-1 - Solids Filtration Technology Assessment Matrix Summary

\begin{tabular}{|c|c|c|c|}
\hline Criteria & Measures and Definitions & Cross-flow Filtration (CFF) & Rotary Micro-filtration (RMF) \\
\hline & $\begin{array}{l}\text { 4.1.6 Minimize number of process } \\
\text { and regulatory samples }\end{array}$ & $\begin{array}{l}\text { Process sampling requirements are minimum (2) } \\
\text { with no requirements for regulatory samples. } \\
\text { - Detailed design may identify more parameters for } \\
\text { measurements. }\end{array}$ & $\begin{array}{l}\text { - Process sampling requirements are minimum (2) } \\
\text { with no requirements for regulatory samples. } \\
\text { - Detailed design may identify more parameters for } \\
\text { measurements. }\end{array}$ \\
\hline & 4.1.7 Batch versus continuous & $\begin{array}{l}\text { - Routinely used as a continuous process for each } \\
\text { campaign. }\end{array}$ & $\begin{array}{l}\text { - Routinely used as a continuous process for each } \\
\text { campaign. }\end{array}$ \\
\hline & $\begin{array}{ll}4.1 .8 & \begin{array}{l}\text { Ease of entry and exit from } \\
\text { standby }\end{array} \\
\end{array}$ & - System shutdown and restart is easy. & - System shutdown and restart is easy. \\
\hline & 4.1.9 Wide operating margin & $\begin{array}{l}\text { - System has an acceptable operating range for the } \\
\text { majority of Hanford tank waste. }\end{array}$ & $\begin{array}{l}\text { - System has an acceptable operating range for the } \\
\text { majority of Hanford tank waste. }\end{array}$ \\
\hline & $\begin{array}{l}\text { 4.1.10 Complexity of transfers to, } \\
\text { from and within Tank Farms }\end{array}$ & $\begin{array}{l}\text { - System does not impose any complex tank waste } \\
\text { transfer requirements to the Tank Farms. }\end{array}$ & $\begin{array}{l}\text { - System does not impose any complex tank waste } \\
\text { transfer requirements to the Tank Farms. }\end{array}$ \\
\hline 4.2 ALARA & $\begin{array}{ll}4.2 .1 & \text { Less required contact } \\
& \text { maintenance is better, etc. }\end{array}$ & $\begin{array}{l}\text { Potentially less contact maintenance is required. } \\
\text { Most maintenance activities will be done at the } \\
\text { IPS (except for the feed pump). } \\
\text { - ALARA must be implemented during the design } \\
\text { phase to assure maximum benefits. Contaminated } \\
\text { components will be flushed and decontaminated } \\
\text { to the extent possible prior to maintenance. } \\
\text { - Waste transfer and feed pumps, transfer piping, } \\
\text { and filter tube bundle will require contact } \\
\text { maintenance. } \\
\text { Design will include remote replacement and } \\
\text { maintenance to the extent possible. } \\
\text { Instrumentation and control systems will invoke } \\
\text { work in radiation area (valve pit) or the IPS } \\
\text { facility, but exposure can be minimized. } \\
\text { Initial installation is in "green field" conditions }\end{array}$ & $\begin{array}{l}\text { - May require maintenance activities to be } \\
\text { performed in a DST pit or components may have } \\
\text { to be removed from the tank for repair or } \\
\text { replacement. } \\
\text { - ALARA must be implemented during the design } \\
\text { phase to assure maximum benefits. Contaminated } \\
\text { components will be flushed and decontaminated } \\
\text { to the extent possible prior to maintenance. } \\
\text { - Waste transfer and feed pumps, transfer line and } \\
\text { filter assemblies will require contact maintenance. } \\
\text { Design will include remote replacement and } \\
\text { maintenance to the extent possible. } \\
\text { Instrumentation and control systems will invoke } \\
\text { work in radiation area (valve pit) or the IPS } \\
\text { facility, but exposure can be minimized. } \\
\text { Replacement of seals will likely be required } \\
\text { during 5-year mission }\end{array}$ \\
\hline
\end{tabular}


Table A-1 - Solids Filtration Technology Assessment Matrix Summary

\begin{tabular}{|c|c|c|c|}
\hline Criteria & Measures and Definitions & Cross-flow Filtration (CFF) & Rotary Micro-filtration (RMF) \\
\hline \multirow[t]{2}{*}{4.3 Reliability } & $\begin{array}{l}\text { 4.3.1 Number of active } \\
\text { components }\end{array}$ & $\begin{array}{l}\text { - Three active components (waste feed/transfer } \\
\text { pumps, and the filter back-flush system). }\end{array}$ & $\begin{array}{l}\text { More }(6-13) \text { active components (waste } \\
\text { feed/transfer pump motors and RMF shaft } \\
\text { motors). }\end{array}$ \\
\hline & $\begin{array}{l}\text { 4.3.2 Reliability of analogous } \\
\text { systems }\end{array}$ & $\begin{array}{l}\text { - Large shell and tube filter systems have not been } \\
\text { used at Hanford. } \\
\text { - Single element metal filters have been used at } \\
\text { Hanford. } \\
\text { - Apparent potential for single point failure with } \\
\text { current design } \\
\text { - Extensive application of technology } \\
\text { - The reliability of the CFF system should be } \\
\text { outstanding. }\end{array}$ & $\begin{array}{l}\text { - No documented use of RMF at Hanford Site or } \\
\text { similar system at the site. } \\
\text { - There is a limited historical data for the reliability } \\
\text { of the filters and rotational motor. } \\
\text { - Apparent redundancy with current design } \\
\text { - The reliability of the RMF system should be } \\
\text { good. }\end{array}$ \\
\hline \multirow[t]{5}{*}{$\begin{array}{l}4.4 \text { Ease and frequency } \\
\text { of maintenance }\end{array}$} & $\begin{array}{ll}\text { 4.4.1 } & \begin{array}{l}\text { Minimize number of support } \\
\text { systems }\end{array} \\
\end{array}$ & $\begin{array}{l}\text { For operation five services- power, air, water, } \\
\mathrm{NaOH} \text { and } \mathrm{HNO}_{3} \text { are required. }\end{array}$ & $\begin{array}{l}\text { - For operation five services- power, instrument air, } \\
\text { water, } \mathrm{NaOH} \text { and } \mathrm{HNO}_{3} \text { are required. }\end{array}$ \\
\hline & 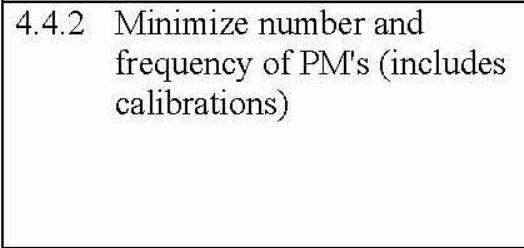 & $\begin{array}{l}\text { - Preventive maintenance activities are anticipated } \\
\text { to be routine with some entry into radiation zone } \\
\text { areas. }\end{array}$ & $\begin{array}{l}\text { Preventive maintenance activities are anticipated } \\
\text { to be routine with some entry into radiation zone } \\
\text { areas. Due to higher number of RMF units, } \\
\text { number of activities will be higher. } \\
\text { - If used with FC, number of RMF units will be } 12 \text {, } \\
\text { increasing number of maintenance activities. }\end{array}$ \\
\hline & $\begin{array}{l}\text { 4.4.3 Minimize maintenance in- } \\
\text { zone entries }\end{array}$ & $\begin{array}{l}\text { - Routine zone entry required once every five year } \\
\text { for repair/replacement of filter tube bundle. }\end{array}$ & $\begin{array}{l}\text { Zone entry is needed every } 2 \text { years for } \\
\text { repair/replacement of mechanical seals. } \\
\text { - Frequency of replacement potentially impacted } \\
\text { by start/stop mode of operation } \\
\text { - Seal reliability impacted by planned start/stop } \\
\text { operation. }\end{array}$ \\
\hline & $\begin{array}{ll}\text { 4.4.4 } & \text { Minimize specialized } \\
\text { equipment and parts }\end{array}$ & $\begin{array}{l}\text { - CFF is a commercial technology which is adapted } \\
\text { to radioactive operation. Adequate spare parts are } \\
\text { needed. }\end{array}$ & $\begin{array}{l}\text { - RMF assembly is specialized equipment but is } \\
\text { based on commercial technology which is } \\
\text { modified for a radioactive operation. Adequate } \\
\text { spare parts will be needed. }\end{array}$ \\
\hline & 4.4.5 Minimize tank entries & $\begin{array}{l}\text { - Routine waste transfer through pipes per tank } \\
\text { farm procedures requiring no special DST tank } \\
\text { entry. Installation of feed pump in the valve pit is } \\
\text { also considered a "DST tank entry". } \\
\text { - Some maintenance activities on feed pump will } \\
\text { require a DST tank entry. }\end{array}$ & $\begin{array}{l}\text { Requires a DST entry to install filtration } \\
\text { equipment on AP-104 riser and some } \\
\text { maintenance activities. }\end{array}$ \\
\hline
\end{tabular}


RPP-RPT-38057, Rev. 0

Table A-1 - Solids Filtration Technology Assessment Matrix Summary

\begin{tabular}{|c|c|c|c|c|}
\hline Criteria & Meas & ures and Definitions & Cross-flow Filtration (CFF) & Rotary Micro-filtration (RMF) \\
\hline \multirow[t]{3}{*}{$\begin{array}{l}4.5 \text { Ease of } \\
\text { Implementation }\end{array}$} & 4.5 .1 & Ease of training & $\begin{array}{l}\text { CFF is a passive unit with an uncomplicated } \\
\text { operating principles leading to non-complex } \\
\text { training needs. }\end{array}$ & $\begin{array}{l}\text { - RMF is a compact design with basic control and } \\
\text { configured for ease of assembly and maintenance, } \\
\text { eliminating complex training needs. }\end{array}$ \\
\hline & 4.5 .2 & Complexity of procedures & - No complexity for O\&M procedure is anticipated. & - No complexity for O\&M procedure is anticipated. \\
\hline & 4.5 .3 & $\begin{array}{l}\text { Similar to other process } \\
\text { facilities on Hanford site }\end{array}$ & - Similar technology is not in use at Hanford Site & - Similar technology is not in use at Hanford Site \\
\hline \multirow[t]{2}{*}{$\begin{array}{l}\text { 4.6 Liquid/solid } \\
\text { secondary waste- }\end{array}$} & 4.6 .1 & $\begin{array}{l}\text { Waste handling compatible } \\
\text { with existing systems as } \\
\text { defined by DOE Order } \\
420.1 \mathrm{~B}-\mathrm{N} / \mathrm{A}\end{array}$ & - N/A. & - N/A \\
\hline & 4.6 .2 & $\begin{array}{l}\text { Minimize operational } \\
\text { impacts associated with } \\
\text { hazardous (generated) waste } \\
\text { handling - N/A }\end{array}$ & $\begin{array}{l}\text { The technology is suited for continuous normal } \\
\text { operation, with no impact for handling of } \\
\text { secondary waste. } \\
\text { - Operation requires suspension once in } 5 \mathrm{yr} \text { for } \\
\text { replacement of filter tube bundles and disposal of } \\
\text { failed equipment. }\end{array}$ & $\begin{array}{l}\text { The technology is suited for continuous normal } \\
\text { operation, with no impact for handling of } \\
\text { secondary waste. } \\
\text { - Operation requires suspension every } 2 \text { year for } \\
\text { replacement of mechanical seals and disposal of } \\
\text { failed equipment. }\end{array}$ \\
\hline \multirow[t]{3}{*}{$\begin{array}{l}5 \text { PROGRAM-MATIC } \\
\text { ASPECTS } \\
5.1 \text { Cost Impact }\end{array}$} & 5.1 .1 & $\begin{array}{l}\text { Capital costs (for } \\
\text { comparative purposes only) }\end{array}$ & $\begin{array}{l}\text { With expected accuracy range of }-30 \% \text { to }+50 \% \text { : } \\
\text { CFF - FC capital costs }=\$ 64 \mathrm{M} \text { to } \$ 140 \mathrm{M}, \mathrm{CFF} \text { - } \\
\text { CSSX capital costs }=\$ 82 \mathrm{M} \text { to } \$ 180 \mathrm{M}, \mathrm{CFF}-\mathrm{IX} \\
\text { capital costs }=\$ 54 \mathrm{M} \text { to } \$ 120 \mathrm{M} \text {. }\end{array}$ & $\begin{array}{l}\text { - With expected accuracy range of }-30 \% \text { to }+50 \% \text { : } \\
\text { RMF - FC capital costs }=\$ 75 \mathrm{M} \text { to } \$ 160 \mathrm{M}, \mathrm{RMF} \text { - } \\
\text { CSSX capital costs }=\$ 87 \mathrm{M} \text { to } \$ 190 \mathrm{M}, \mathrm{RMF}-\mathrm{IX} \\
\text { capital costs }=\$ 59 \mathrm{M} \text { to } \$ 130 \mathrm{M} \text {. }\end{array}$ \\
\hline & 5.1 .2 & $\begin{array}{l}\text { Life cycle costs (for } \\
\text { comparative purposes only) }\end{array}$ & $\begin{array}{l}\text { With expected accuracy range of }-30 \% \text { to }+50 \% \\
\text { (applied to capital cost contribution): CFF - FC } \\
\text { life cycle costs (w/o T\&R) }=\$ 170 \mathrm{M} \text { to } \$ 240 \mathrm{M} \text {, } \\
\text { CFF - CSSX life cycle costs (w/ evap) }=\$ 190 \mathrm{M} \\
\text { to } \$ 290 \mathrm{M} \text {, CFF - IX life cycle costs }=\$ 140 \mathrm{M} \text { to } \\
\$ 200 \mathrm{M} \text {. }\end{array}$ & $\begin{array}{l}\text { With expected accuracy range of }-30 \% \text { to }+50 \% \\
\text { (applied to capital cost contribution): RMF - FC } \\
\text { life cycle costs (w/o T\&R) }=\$ 190 \mathrm{M} \text { to } \$ 280 \mathrm{M} \text {, } \\
\text { RMF - CSSX life cycle costs (w/ evap) }=\$ 210 \mathrm{M} \\
\text { to } \$ 310 \mathrm{M}, \mathrm{RMF} \text { - IX life cycle costs }=\$ 150 \mathrm{M} \text { to } \\
\$ 220 \mathrm{M} \text {. }\end{array}$ \\
\hline & 5.1 .3 & $\begin{array}{l}\text { Cost profile (for comparative } \\
\text { purposes only) }\end{array}$ & $\begin{array}{l}\text { Both the lowest capital cost and the lowest life } \\
\text { cycle cost result from pairing CFF with IX-sRF. } \\
\text { (for comparative purposes only) }\end{array}$ & $\begin{array}{l}\text { - Both the highest capital cost and highest life cycle } \\
\text { cost result from pairing RMF with CSSX. (for } \\
\text { comparative purposes only) }\end{array}$ \\
\hline
\end{tabular}


RPP-RPT-38057, Rev. 0

Table A-1 - Solids Filtration Technology Assessment Matrix Summary

\begin{tabular}{|c|c|c|c|}
\hline Criteria & Measures and Definitions & Cross-flow Filtration (CFF) & Rotary Micro-filtration (RMF) \\
\hline \multirow[t]{4}{*}{5.2 Schedule Impact } & $\begin{array}{ll}5.2 .1 & \begin{array}{l}\text { Overall schedule } \\
\text { (confidence) - for } \\
\text { comparative purposes only }\end{array} \\
\end{array}$ & $\begin{array}{l}\text { - Scheduling of "green field" activities has a lower } \\
\text { degree of uncertainty. }\end{array}$ & $\begin{array}{l}\text { - Scheduling of work in tank farms has a higher } \\
\text { degree of uncertainty.. }\end{array}$ \\
\hline & 5.2.2 Licensing & $\begin{array}{l}\text { Due to considerable experience with this } \\
\text { technology at various DOE sites (including } \\
\text { WTP), its safety analysis should not impact } \\
\text { overall schedule. }\end{array}$ & $\begin{array}{l}\text { - Due to lack of enough design and process } \\
\text { information, safety analysis will require } \\
\text { additional efforts and time. }\end{array}$ \\
\hline & 5.2.3 Permitting & $\begin{array}{l}\text { Does not impact RCRA part B permitting } \\
\text { schedule as it is the first step of the total } \\
\text { pretreatment process and does not produce any } \\
\text { secondary waste. }\end{array}$ & $\begin{array}{l}\text { Does not impact RCRA part B permitting } \\
\text { schedule as it is the first step of the total } \\
\text { pretreatment process and does not produce any } \\
\text { secondary waste. }\end{array}$ \\
\hline & $5.2 .4 \quad \mathrm{D} \& \mathrm{D}$ & $\begin{array}{l}\text { - } \begin{array}{l}\text { Considerations for D\&D will be accommodated } \\
\text { during the IPS design. Negligible impact on IPS } \\
\text { schedule. }\end{array} \\
\end{array}$ & $\begin{array}{l}\text { - Considerations for D\&D will be accommodated } \\
\text { during the IPS design. Negligible impact on IPS } \\
\text { schedule. }\end{array}$ \\
\hline \multirow[t]{2}{*}{5.3 DST Space } & $\begin{array}{l}\text { 5.3.1 How fast DST space is made } \\
\text { available - N/A }\end{array}$ & $\begin{array}{l}\text { - Does not directly impact rate of freed up DST } \\
\text { space. }\end{array}$ & $\begin{array}{l}\text { Does not directly impact rate of freed up DST } \\
\text { space. }\end{array}$ \\
\hline & $\begin{array}{l}\text { 5.3.2 Amount of DST space }-\mathrm{N} / \\
\text { A }\end{array}$ & $\begin{array}{l}\text { - Generates a total of } 200,000 \text { gals of } 20 \mathrm{wt} \% \\
\text { entrained solids waiting to be processed as HLW } \\
\text { feed. } \\
\text { - Larger CFF system volume and higher filter } \\
\text { cleaning frequency will generate neutralized wash } \\
\text { solution volumes significantly ( } 10+\text { times) greater } \\
\text { than RMF. }\end{array}$ & $\begin{array}{l}\text { - Generates a total of } 200,000 \text { gals of } 20 \% \\
\text { entrained solids waiting to be processed as HLW } \\
\text { feed. } \\
\text { - Smaller RMF system volume and lower filter } \\
\text { cleaning frequency will generate neutralized wash } \\
\text { solution volumes significantly less than CFF. } \\
\text { - Neutralized wash solution volumes for FC will be } \\
\sim 2-3 \text { times than those for CSSX or IX-sRF due to } \\
\text { increased number of filters. }\end{array}$ \\
\hline
\end{tabular}


Table A-1 - Solids Filtration Technology Assessment Matrix Summary

\begin{tabular}{|c|c|c|c|}
\hline Criteria & Measures and Definitions & Cross-flow Filtration (CFF) & Rotary Micro-filtration (RMF) \\
\hline \multirow{8}{*}{$\begin{array}{l}5.4 \text { Impacts to WTP \& } \\
\text { Supplemental } \\
\text { Treatment }\end{array}$} & $\begin{array}{ll}\text { 5.4.1 Production rate impact - } \\
\text { N/A }\end{array}$ & $\begin{array}{l}\text { - No production rate impact to WTP (HLW and } \\
\text { LAW) or supplemental Treatment Plant. }\end{array}$ & $\begin{array}{l}\text { - No production rate impact to WTP (HLW and } \\
\text { LAW) or supplemental Treatment Plant. }\end{array}$ \\
\hline & 5.4.2 Mission duration $-\mathrm{N} / \mathrm{A}$ & $\begin{array}{l}\text { - No impact to overall WTP primary mission } \\
\text { duration. }\end{array}$ & $\begin{array}{l}\text { - No impact to overall WTP primary mission } \\
\text { duration. }\end{array}$ \\
\hline & $\begin{array}{ll}5.4 .3 & \text { Number of high and low } \\
\text { level packages - N/A }\end{array}$ & $\begin{array}{l}\text { - No impact on high or low level waste packages to } \\
\text { be produced by WTP or supplemental treatment } \\
\text { plants. }\end{array}$ & $\begin{array}{l}\text { - No impact on high or low level waste packages to } \\
\text { be produced by WTP or supplemental treatment } \\
\text { plants. }\end{array}$ \\
\hline & $\begin{array}{l}\text { 5.4.4 Lessons Learned benefits for } \\
\text { WTP pretreatment }\end{array}$ & $\begin{array}{l}\text { IPS CFF deployment, start up and operational } \\
\text { experience will provide lessons learned feedback } \\
\text { to the WTP pretreatment facility. }\end{array}$ & $\begin{array}{l}\text { - RMF process does not provide lessons learned for } \\
\text { WTP. }\end{array}$ \\
\hline & 5.4.5 Technology transfer to WTP & - Does not provide technology transfer for WTP. & $\begin{array}{l}\text { - RMF can provide technology transfer to WTP if } \\
\text { for any reason CFF did not perform in the WTP. } \\
\text { RMF can also provide filtration support to WTP } \\
\text { if needed. }\end{array}$ \\
\hline & 5.4.6 ALARA - N/A & - No ALARA impact to WTP. & - No ALARA impact to WTP. \\
\hline & 5.4.7 Diversity of technology & - CFF does not provide technology diversity. & $\begin{array}{l}\text { - RMF provides technology diversity for waste } \\
\text { filtration needs at Hanford. This technology can } \\
\text { be adapted to other tanks in tank farms. }\end{array}$ \\
\hline & $\begin{array}{l}\text { 5.4.8 Positive programmatic } \\
\text { impacts and opportunities }\end{array}$ & $\begin{array}{l}\text { Provide potential cost reduction through shared } \\
\text { development costs and reduced WTP startup costs } \\
\text { and reduces technical and schedule risk through } \\
\text { lessons learned. }\end{array}$ & - No programmatic opportunities are identified yet. \\
\hline \multirow{4}{*}{$\begin{array}{l}5.5 \text { Impacts to other } \\
\text { facilities e.g., ETF, } \\
\text { LAB }\end{array}$} & $\begin{array}{l}\text { 5.5.1 Analytical equipment, } \\
\text { methods, and capacity - N/A }\end{array}$ & $\begin{array}{l}\text { No impact to analytical laboratories (in-line } \\
\text { measurement of solids concentration). }\end{array}$ & $\begin{array}{l}\text { - No impact to analytical laboratories (solids are } \\
\text { returned directly to feed tank AP-104). }\end{array}$ \\
\hline & $\begin{array}{ll}5.5 .2 \text { Compliance to ETF WAC - } \\
\text { N/A }\end{array}$ & - Does not impact ETF operation. & - Does not impact ETF operation. \\
\hline & 5.5.3 ALARA & $\begin{array}{l}\text { - Because CFF included as part of new IPS facility, } \\
\text { ALARA will be more easily incorporated into its } \\
\text { process design. } \\
\text { - Initial installation is under "green field" } \\
\text { conditions }\end{array}$ & $\begin{array}{l}\text { - Because RMF is being installed in an existing } \\
\text { DST, ALARA will be more difficult to } \\
\text { incorporate into its process design. }\end{array}$ \\
\hline & \begin{tabular}{|ll}
5.5 .4 & Number of Evaporator \\
campaigns - N/A
\end{tabular} & $\begin{array}{l}\text { - Does not directly impact 242-A Evaporator } \\
\text { campaigns. }\end{array}$ & $\begin{array}{l}\text { - Does not directly impact 242-A Evaporator } \\
\text { campaigns. }\end{array}$ \\
\hline
\end{tabular}


RPP-RPT-38057, Rev. 0

Table A-1 - Solids Filtration Technology Assessment Matrix Summary

\begin{tabular}{|c|c|c|c|}
\hline Criteria & Measures and Definitions & Cross-flow Filtration (CFF) & Rotary Micro-filtration (RMF) \\
\hline \multirow[t]{2}{*}{$\begin{array}{l}5.6 \text { Resources and } \\
\text { materials }\end{array}$} & $\begin{array}{ll}\text { 5.6.1 } & \text { Availability of Key Skills, } \\
& \text { Critical Materials, Qualified } \\
& \text { Vendors }\end{array}$ & $\begin{array}{l}\text { - } \text { CFF unit can be assembled by multiple } \\
\text { experienced vendors with limited technical } \\
\text { oversight. } \\
\text { - CFF requires very high capacity recirculation } \\
\text { pump. } \\
\text { - German supplier provides best quality filter } \\
\text { material, but not seen as sole source }\end{array}$ & $\begin{array}{l}\text { RMF will require some technological } \\
\text { development resources to support re-engineering } \\
\text { of the system for Hanford tank specific design. } \\
\text { - Only a single vendor has been identified who is } \\
\text { capable of assembling these modules and the } \\
\text { vendor will require strong participation of } \\
\text { technology experts from the DOE sites. }\end{array}$ \\
\hline & $\begin{array}{ll}\text { 5.6.2 Stability of Critical Resource } \\
\text { Pricing }\end{array}$ & $\begin{array}{l}\text { - Does not require any special or unusual material } \\
\text { of construction. } \\
\text { - No specific critical material pricing risk is } \\
\text { anticipated. }\end{array}$ & $\begin{array}{l}\text { - Does not require any special or unusual material } \\
\text { of construction. } \\
\text { - Due to a single source vendor, may be subjected } \\
\text { to some pricing risk. }\end{array}$ \\
\hline
\end{tabular}


Table A-2 - Solids Filtration Technology Assessment Decision Calculator Results (extracted from CH2M HILL 2008f)

\begin{tabular}{|c|c|c|c|c|c|c|}
\hline \multirow[t]{2}{*}{ \# } & \multirow[t]{2}{*}{ RPP-PLAN-37558 DECISION PLAN CRITERIA } & \multirow{2}{*}{$\begin{array}{l}\text { Weight } \\
(\%)\end{array}$} & \multicolumn{2}{|c|}{ CFF } & \multicolumn{2}{|c|}{$\mathbf{R M}$} \\
\hline & & & $\begin{array}{c}\text { Raw } \\
\text { Ranking }\end{array}$ & $\begin{array}{l}\text { Weighted } \\
\text { Value }\end{array}$ & $\begin{array}{c}\text { Raw } \\
\text { Ranking }\end{array}$ & $\begin{array}{l}\text { Weighted } \\
\text { Value }\end{array}$ \\
\hline \multirow{2}{*}{$\begin{array}{r}1.0 \\
1.1\end{array}$} & \multirow{2}{*}{$\begin{array}{l}\text { Safety } \\
\text { Process Safety }\end{array}$} & 25 & & & & \\
\hline & & & & & & \\
\hline 1.1 .1 & $\begin{array}{l}\text { Quantity of material at risk (MAR) - radiological and chemical - less } \\
\text { is better }\end{array}$ & & 5 & 0.94 & 5 & 0.94 \\
\hline \multirow{2}{*}{$\begin{array}{l}1.1 .2 \\
1.1 .3\end{array}$} & \multirow{2}{*}{$\begin{array}{l}\text { Concentration of radiological and chemical MAR - less is better } \\
\text { Dispersability of the MAR - less dispersible form is better (e.g., solids } \\
\text { over liquids over powders over gases) }\end{array}$} & & 5 & 0.94 & 5 & 0.94 \\
\hline & & & 5 & 0.94 & 5 & 0.94 \\
\hline 1.1 .4 & $\begin{array}{l}\text { Dispersive energy, e.g., heat, off gassing, pressure, etc. inherent in the } \\
\text { process - less dispersive energy is better }\end{array}$ & & 4 & 0.75 & 5 & 0.94 \\
\hline \multirow{2}{*}{$\begin{array}{l}1.1 .5 \\
1.1 .6\end{array}$} & \multirow{2}{*}{$\begin{array}{l}\text { Process Stability - including ease of process control/shutdown -- } \\
\text { easier/faster process shutdown is better } \\
\text { Process that does not create a new or exacerbate an existing Tank } \\
\text { Farm hazard is preferred to one that does }\end{array}$} & & 5 & 0.94 & 5 & 0.94 \\
\hline & & & 5 & 0.94 & 5 & 0.94 \\
\hline 1.1 .7 & $\begin{array}{l}\text { Less fire hazard (e.g. less quantity of combustibles, including } \\
\text { flammable gas, less flammable combustibles, etc.) }\end{array}$ & & 4 & 0.75 & 5 & 0.94 \\
\hline \multirow[t]{2}{*}{1.1 .8} & \multirow{2}{*}{$\begin{array}{l}\text { Reactive Chemicals - Process with less reactive chemicals (reactivity) } \\
\text { is better } \\
\text { Criticality Safety }\end{array}$} & & 5 & 0.94 & 4 & 0.75 \\
\hline & & & & & & \\
\hline 1.2 .1 & $\begin{array}{l}\text { A Process that is inherently sub critical is preferred over a process that } \\
\text { relies on criticality controls }\end{array}$ & & 5 & 1.25 & 5 & 1.25 \\
\hline \multirow{3}{*}{$\begin{array}{l}1.3 \\
1.3 .1\end{array}$} & \multirow{3}{*}{$\begin{array}{l}\text { Industrial Safety and Hygiene } \\
\text { Less hazards/less severe hazardous is better (e.g.,...) }\end{array}$} & & & & & \\
\hline & & & 5 & 3.75 & 5 & 3.75 \\
\hline & & & Subtotals & 12 & & 12 \\
\hline 2.0 & Regulator and Stakeholder Acceptance & 20 & & & & \\
\hline 2.1 & Achieve Tribal Nations / stakeholders' acceptance & & & & & \\
\hline \multirow{2}{*}{$\begin{array}{l}2.1 .1 \\
2.1 .2\end{array}$} & \multirow{2}{*}{$\begin{array}{l}\text { Early waste treatment enabled } \\
\text { Land usage (more contaminated ground) }\end{array}$} & & 5 & 2.00 & 5 & 2.00 \\
\hline & & & 6 & 2.40 & 7 & 2.80 \\
\hline
\end{tabular}


RPP-RPT-38057, Rev. 0

Table A-2 - Solids Filtration Technology Assessment Decision Calculator Results (extracted from CH2M HILL 2008f)

\begin{tabular}{|c|c|c|c|c|c|c|}
\hline \multirow[t]{2}{*}{ \# } & \multirow[t]{2}{*}{ RPP-PLAN-37558 DECISION PLAN CRITERIA } & \multirow{2}{*}{$\begin{array}{l}\text { Weight } \\
(\%)\end{array}$} & \multicolumn{2}{|c|}{ CFF } & \multicolumn{2}{|c|}{$\mathbf{R M}$} \\
\hline & & & $\begin{array}{l}\text { Raw } \\
\text { Ranking }\end{array}$ & $\begin{array}{l}\text { Weighted } \\
\text { Value }\end{array}$ & $\begin{array}{c}\text { Raw } \\
\text { Ranking }\end{array}$ & $\begin{array}{l}\text { Weighted } \\
\text { Value }\end{array}$ \\
\hline 2.2 & Achieve regulators' acceptance & & & & & \\
\hline 2.2 .1 & $\begin{array}{l}\text { Compliance with applicable regulations (RCRA, CAA, NESHAPS, } \\
\text { NEPA/SEPA, NPDES, DOE Orders) }\end{array}$ & & 5 & 1.50 & 4 & 1.20 \\
\hline 2.2 .2 & Impact to Disposal System Performance & & 5 & 1.50 & 5 & 1.50 \\
\hline \multirow{3}{*}{$\begin{array}{l}2.2 .3 \\
2.2 .4\end{array}$} & \multirow{2}{*}{$\begin{array}{l}\text { Secondary Waste Form and Quantity } \\
\text { Potential impacts to other permitted facilities }\end{array}$} & & 5 & 1.50 & 5 & 1.50 \\
\hline & & & 5 & 1.50 & 5 & 1.50 \\
\hline & & & Subtotals & 10 & & 11 \\
\hline 3.0 & Technical Maturity/Flexibility & 20 & & & & \\
\hline \multirow{3}{*}{$\begin{array}{l}3.1 \\
3.1 .1 \\
3.1 .2\end{array}$} & \multirow{3}{*}{$\begin{array}{l}\text { Technology Readiness Level } \\
\text { Technology Readines Level Number } \\
\text { Effort to mature technology }\end{array}$} & & & & & \\
\hline & & & 5 & 2.00 & 5 & 2.00 \\
\hline & & & 6 & 2.40 & 4 & 1.60 \\
\hline 3.1 .3 & Probability of success & & 8 & 3.20 & 8 & 3.20 \\
\hline 3.2 & Process Flexibility and robustness & & & & & \\
\hline \multirow{3}{*}{$\begin{array}{l}3.2 .1 \\
3.2 .2 \\
3.2 .3\end{array}$} & \multirow{3}{*}{$\begin{array}{l}\text { Ability to process a variety of feeds } \\
\text { Ability to adjust process rate } \\
\text { Flexibility to modify product }\end{array}$} & & 5 & 0.80 & 5 & 0.80 \\
\hline & & & 5 & 0.80 & 6 & 0.96 \\
\hline & & & 5 & 0.80 & 5 & 0.80 \\
\hline 3.2 .4 & Ability to expand & & 0 & 0.00 & 0 & 0.00 \\
\hline 3.2 .5 & Recover from out of spec product & & 5 & 0.80 & 4 & 0.64 \\
\hline \multirow[t]{2}{*}{3.2 .6} & \multirow[t]{2}{*}{ Technology applicability to other DOE complex projects } & & 5 & 0.80 & 6 & 0.96 \\
\hline & & & Subtotals & 12 & & 11 \\
\hline 4.0 & Operability and Maintainability & 15 & & & & \\
\hline 4.1 & Ease of Process control and operation & & & & & \\
\hline \multirow{3}{*}{$\begin{array}{l}4.1 .1 \\
4.1 .2 \\
4.1 .3\end{array}$} & \multirow{3}{*}{$\begin{array}{l}\text { Minimize number and frequency of surveillances } \\
\text { Minimize number of people to operate } \\
\text { Ease of startup and shutdown }\end{array}$} & & 5 & 0.19 & 5 & 0.19 \\
\hline & & & 5 & 0.19 & 5 & 0.19 \\
\hline & & & 6 & 0.23 & 5 & 0.19 \\
\hline 4.1.4 & Minimize system complexity & & 5 & 0.19 & 5 & 0.19 \\
\hline 4.1 .5 & Minimize number of chemicals needed & & 5 & 0.19 & 5 & 0.19 \\
\hline \multirow{2}{*}{$\begin{array}{l}4.1 .6 \\
4.1 .7\end{array}$} & \multirow{2}{*}{$\begin{array}{l}\text { Minimize number of process and regulatory samples } \\
\text { Batch verses continuous }\end{array}$} & & 5 & 0.19 & 5 & 0.19 \\
\hline & & & 5 & 0.19 & 5 & 0.19 \\
\hline 4.1 .8 & Ease of entry and exit from standby & & 5 & 0.19 & 5 & 0.19 \\
\hline
\end{tabular}


RPP-RPT-38057, Rev. 0

Table A-2 - Solids Filtration Technology Assessment Decision Calculator Results (extracted from CH2M HILL 2008f)

\begin{tabular}{|c|c|c|c|c|c|c|}
\hline \multirow[t]{2}{*}{ \# } & \multirow[t]{2}{*}{ RPP-PLAN-37558 DECISION PLAN CRITERIA } & \multirow{2}{*}{$\begin{array}{l}\text { Weight } \\
(\%)\end{array}$} & \multicolumn{2}{|c|}{ CFF } & \multicolumn{2}{|c|}{ RM } \\
\hline & & & $\begin{array}{c}\text { Raw } \\
\text { Ranking }\end{array}$ & $\begin{array}{l}\text { Weighted } \\
\text { Value }\end{array}$ & $\begin{array}{c}\text { Raw } \\
\text { Ranking }\end{array}$ & $\begin{array}{l}\text { Weighted } \\
\text { Value }\end{array}$ \\
\hline 4.1 .9 & Wide operating margin & & 5 & 0.19 & 5 & 0.19 \\
\hline 4.1 .10 & Complexity of transfers to, from and within Tank Farms & & 5 & 0.19 & 5 & 0.19 \\
\hline 4.2 & ALARA & & & & & \\
\hline 4.2 .1 & Less required contact maintenance is better, etc. ( $\mathrm{rad}$ and tox) & & 5 & 1.50 & 4 & 1.20 \\
\hline 4.3 & Reliability & & & & & \\
\hline 4.3 .1 & Number of active components & & 6 & 1.04 & 5 & 0.86 \\
\hline 4.3 .2 & Reliability of analogous systems & & 5 & 0.86 & 5 & 0.86 \\
\hline 4.4 & Ease and frequency of maintenance & & & & & \\
\hline 4.4 .1 & Minimize number of support systems & & 5 & 0.30 & 5 & 0.30 \\
\hline 4.4.2 & Minimize number and frequency of PM's & & 5 & 0.30 & 4 & 0.24 \\
\hline 4.4 .3 & Minimize maintenance in zone entries & & 6 & 0.36 & 4 & 0.24 \\
\hline 4.4 .4 & Minimize specialized equipment and parts & & 5 & 0.30 & 5 & 0.30 \\
\hline 4.4 .5 & Minimize tank entries & & 5 & 0.30 & 5 & 0.30 \\
\hline 4.5 & Ease of Implementation & & & & & \\
\hline 4.5 .1 & Ease of training & & 5 & 0.30 & 5 & 0.30 \\
\hline 4.5 .2 & Complexity of procedures & & 5 & 0.30 & 5 & 0.30 \\
\hline 4.5 .3 & Similar to other process facilities on site & & 5 & 0.30 & 5 & 0.30 \\
\hline 4.6 & Liquid/solid secondary waste & & & & & \\
\hline 4.6 .1 & $\begin{array}{l}\text { Waste handling compatible with existing systems as defined by DOE } \\
\text { Order } 420.1 \mathrm{~B}\end{array}$ & & 0 & & 0 & \\
\hline 4.6 .2 & $\begin{array}{l}\text { Minimize operational impacts associated with hazardous (generated) } \\
\text { waste handling }\end{array}$ & & 0 & & 0 & \\
\hline & & & Subtotals & 8 & & 7 \\
\hline 5.0 & Programmatic Aspects & 20 & & & & \\
\hline 5.1 & Cost Impacts & & & & & \\
\hline 5.1 .1 & Capital costs & & 8 & 2.13 & 5 & 1.33 \\
\hline 5.1 .2 & Life cycle costs & & 8 & 2.13 & 4 & 1.07 \\
\hline 5.1 .3 & Cost profile & & 8 & 2.13 & 4 & 1.07 \\
\hline 5.2 & Schedule Impact & & & & & \\
\hline 5.2 .1 & Overall schedule (confidence) & & 7 & 1.23 & 5 & 0.88 \\
\hline
\end{tabular}


RPP-RPT-38057, Rev. 0

Table A-2 - Solids Filtration Technology Assessment Decision Calculator Results (extracted from CH2M HILL 2008f)

\begin{tabular}{|c|c|c|c|c|c|c|}
\hline \multirow[t]{2}{*}{ \# } & \multirow[t]{2}{*}{ RPP-PLAN-37558 DECISION PLAN CRITERIA } & \multirow{2}{*}{$\begin{array}{l}\text { Weight } \\
(\%)\end{array}$} & \multicolumn{2}{|c|}{ CFF } & \multicolumn{2}{|c|}{ RM } \\
\hline & & & $\begin{array}{c}\text { Raw } \\
\text { Ranking }\end{array}$ & $\begin{array}{l}\text { Weighted } \\
\text { Value }\end{array}$ & $\begin{array}{c}\text { Raw } \\
\text { Ranking }\end{array}$ & $\begin{array}{l}\text { Weighted } \\
\text { Value }\end{array}$ \\
\hline 5.2 .2 & Licensing & & 6 & 1.05 & 5 & 0.88 \\
\hline 5.2 .3 & Permitting & & 5 & 0.88 & 5 & 0.88 \\
\hline 5.2 .4 & $\mathrm{D} \& \mathrm{D}$ & & 5 & 0.88 & 5 & 0.88 \\
\hline \multirow{3}{*}{$\begin{array}{l}5.3 \\
5.3 .1 \\
5.3 .2\end{array}$} & \multirow{3}{*}{$\begin{array}{l}\text { DST Space } \\
\text { How fast DST space is made available } \\
\text { Amount of DST space }\end{array}$} & & & & & \\
\hline & & & 0 & & 0 & \\
\hline & & & 0 & & 0 & \\
\hline 5.4 & $\begin{array}{l}\text { Impacts to WTP and Supplemental Treatment, positive and } \\
\text { negative }\end{array}$ & & & & & \\
\hline \multirow{3}{*}{$\begin{array}{l}5.4 .1 \\
5.4 .2 \\
5.4 .3\end{array}$} & \multirow{3}{*}{$\begin{array}{l}\text { Production rate impact } \\
\text { Mission duration } \\
\text { Number of high and low level packages }\end{array}$} & & 0 & & 0 & \\
\hline & & & 0 & & 0 & \\
\hline & & & 0 & & 0 & \\
\hline 5.4 .4 & Lessons Learned benefits for WTP pretreatment & & 3 & 0.23 & 2 & 0.15 \\
\hline 5.4 .5 & Technology transfer to WTP & & 1 & 0.08 & 2 & 0.15 \\
\hline \multirow{3}{*}{$\begin{array}{l}5.4 .6 \\
5.4 .7 \\
5.4 .8\end{array}$} & \multirow{3}{*}{$\begin{array}{l}\text { ALARA } \\
\text { Diversity of technology } \\
\text { Positive programmatic impacts and opportunities }\end{array}$} & & 0 & & 0 & \\
\hline & & & 1 & 0.08 & 2 & 0.15 \\
\hline & & & 2 & 0.15 & 1 & 0.08 \\
\hline 5.5 & Impacts to other facilities e.g., ETF, LAB & & & & & \\
\hline 5.5 .1 & Analytical equipment, methods, and capacity & & 0 & & 0 & \\
\hline \multirow{2}{*}{$\begin{array}{l}5.5 .2 \\
5.5 .3\end{array}$} & \multirow{2}{*}{$\begin{array}{l}\text { Compliance to ETF WAC } \\
\text { ALARA }\end{array}$} & & 0 & & 0 & \\
\hline & & & 5 & 0.50 & 4 & 0.40 \\
\hline 5.5 .4 & Number of Evaporator campaigns & & 0 & & 0 & \\
\hline 5.6 & Resources and materials & & & & & \\
\hline \multirow{4}{*}{$\begin{array}{l}5.6 .1 \\
5.6 .2\end{array}$} & \multirow{3}{*}{$\begin{array}{l}\text { Availability of Key Skills, Critical Materials, Qualified Vendors } \\
\text { Stability of Critical Resource Pricing }\end{array}$} & & 6 & 0.30 & 4 & 0.20 \\
\hline & & & 5 & 0.25 & 5 & 0.25 \\
\hline & & & Subtotals & 12 & & 8 \\
\hline & TOTALS & & 301 & 54 & 278 & 49 \\
\hline
\end{tabular}




\section{ATTACHMENT B. CESIUM SEPARATION TECHNOLOGY DECISION SUPPORT BOARD ASSESSMENT}

Table B-1 - Cesium Separation Technology Assessment Summary Matrix

\begin{tabular}{|c|c|c|c|c|}
\hline Criteria & $\begin{array}{c}\text { Measures and } \\
\text { Definitions }\end{array}$ & Fractional Crystallization (FC) & $\begin{array}{l}\text { Caustic-Side Solvent Extraction } \\
\text { (CSSX) }\end{array}$ & Ion Exchange with sRF (IX-sRF) \\
\hline \multirow[t]{4}{*}{$\begin{array}{l}1 \text { SAFETY } \\
1.1 \text { Process Safety }\end{array}$} & $\begin{array}{l}1.1 .1 \\
\text { Quantity of material at } \\
\text { risk (MAR) - } \\
\text { radiological and } \\
\text { chemical - less is better }\end{array}$ & $\begin{array}{l}\text { - The radionuclide (Ci) MAR quantity } \\
\text { ranges are E+04 to E+05 for feed } \\
\text { receipt tank. Since FC has the larger } \\
\text { feed tank it has larger quantity of } \\
\text { MAR. } \\
\text { - The radionuclide (Ci) MAR quantity } \\
\text { ranges are E+04 to E+05 for Cs } \\
\text { Product tank. } \\
\text { - The radionuclide (Ci) MAR quantity } \\
\text { ranges are } 8.65 \mathrm{E}+01 \text { to } 4.46 \mathrm{E}+02 \\
\text { for LAW Product tank. } \\
\text { - Toxicological doses are driven by the } \\
\text { chemicals in the DST wastes. }\end{array}$ & $\begin{array}{l}\text { - The radionuclide (Ci) MAR quantity } \\
\text { ranges are E+04 to E+05 for feed } \\
\text { receipt tank. } \\
\text { - The radionuclide (Ci) MAR quantity } \\
\text { ranges are E+04 for Cs Product tank. } \\
\text { - The LAW Product tank MAR is } \\
\text { similar to the IX technology. } \\
\text { - Toxicological doses are driven by the } \\
\text { chemicals in the DST wastes and not } \\
\text { process chemicals. }\end{array}$ & $\begin{array}{l}\text { - The radionuclide (Ci) MAR quantity } \\
\text { ranges are E+04 to E+05 for feed } \\
\text { receipt tank. } \\
\text { - The radionuclide (Ci) MAR quantity } \\
\text { ranges are E+04 for Cs Product tank. } \\
\text { - The radionuclide (Ci) MAR quantity } \\
\text { ranges are } 2.17 \mathrm{E}+02 \text { to } 1.15 \mathrm{E}+03 \\
\text { for LAW Product tank. } \\
\text { - Toxicological doses are driven by the } \\
\text { chemicals in the DST wastes and not } \\
\text { process chemicals. }\end{array}$ \\
\hline & $\begin{array}{l}1.1 .2 \\
\text { Concentration of } \\
\text { radiological and } \\
\text { chemical MAR - less is } \\
\text { better - focused on } \\
\text { toxicological over } \\
\text { radiological }\end{array}$ & $\begin{array}{l}\text { ULDs of the LAW ( } 0.5 \text { to } 2.8) \text { to the } \\
\text { WTP is very low (similar for all three } \\
\text { technologies). ULDs range for Cs } \\
\text { return stream is } 99.2 \text { to } 515.6 \text {. }\end{array}$ & $\begin{array}{l}\text {-ULDs of the LAW (1.3 to 6.7) to the } \\
\text { WTP are very low. ULDs range for } \\
\text { Cs return stream is } 33.2 \text { to } 278.2 \text {. The } \\
\text { strip solution has ULD values up to } \\
700 \text {. }\end{array}$ & $\begin{array}{l}\text { - ULDs of the LAW (1.3 to 6.7) to the } \\
\text { WTP are very low. ULDs range for } \\
\text { Cs return stream is } 155.4 \text { to } 342.0 \text {. }\end{array}$ \\
\hline & $\begin{array}{l}1.1 .3 \\
\text { Dispersability of the } \\
\text { MAR - less dispersible } \\
\text { form is better (e.g., } \\
\text { solids over liquids over } \\
\text { powders over gases) }\end{array}$ & $\begin{array}{l}\text { - Minimal dispersability as MAR } \\
\text { remains in a liquid phase. } \\
\text { - Some of the MAR can be entrained } \\
\text { in the vapor phase. }\end{array}$ & $\begin{array}{l}\text { - Minimal dispersability as MAR } \\
\text { always remains in a liquid phase in } \\
\text { non-fire type accidents. } \\
\text { - The MAR is mixed with the solvent. }\end{array}$ & $\begin{array}{l}\text { - Minimal dispersability as MAR } \\
\text { remains in a liquid phase. } \\
\text { - Dispersibility of MAR for resin } \\
\text { column could be problematic in a } \\
\text { fire accident when IX column is } \\
\text { loaded with Cs }\end{array}$ \\
\hline & $\begin{array}{l}1.1 .4 \\
\text { Dispersive energy, e.g., } \\
\text { heat, off gassing, } \\
\text { pressure, etc. inherent in } \\
\text { the process - less } \\
\text { dispersive energy is } \\
\text { better }\end{array}$ & $\begin{array}{l}\text { - Dispersion energy comes mainly } \\
\text { from kinetic energy from transfer } \\
\text { pumps and process steam and } \\
\text { gravitational energy from tanks and } \\
\text { vessels. } \\
\text { - The FC recirculation pumps are rated } \\
\text { for over } 5000 \text { gpm. } \\
\text { - Rotational speed of centrifuge is } \\
1200 \mathrm{rpm}\end{array}$ & $\begin{array}{l}\text { Dispersive energy comes from } \\
\text { rotational kinetic energy, reactive } \\
\text { chemical energy, organic solvents } \\
\text { (fires), and gravitational energy from } \\
\text { tanks and vessels. }\end{array}$ & $\begin{array}{l}\text { - Dispersive energy can be kinetic } \\
\text { energy (pumps), reactive chemical } \\
\text { energy, H2 gassing, and } \\
\text { gravitational energy from tanks and } \\
\text { vessels. } \\
\text { - Decay heat on resin column } \\
\text { accounted for in } 1.1 .7\end{array}$ \\
\hline
\end{tabular}


RPP-RPT-38057, Rev. 0

Table B-1 - Cesium Separation Technology Assessment Summary Matrix

\begin{tabular}{|c|c|c|c|c|}
\hline Criteria & $\begin{array}{l}\text { Measures and } \\
\text { Definitions }\end{array}$ & Fractional Crystallization (FC) & $\begin{array}{l}\text { Caustic-Side Solvent Extraction } \\
\text { (CSSX) }\end{array}$ & Ion Exchange with sRF (IX-sRF) \\
\hline & $\begin{array}{l}1.1 .5 \\
\text { Process Stability - } \\
\text { including ease of } \\
\text { process } \\
\text { control/shutdown -- } \\
\text { easier/faster process } \\
\text { shutdown is better }\end{array}$ & $\begin{array}{l}\text { - The FC does operate at a slightly } \\
\text { evaluated temperature. Boiling can } \\
\text { be easy stopped by reducing the } \\
\text { vacuum. Long term shut down } \\
\text { requires dumping or flushing of the } \\
\text { solution to minimize further solids } \\
\text { formation. }\end{array}$ & $\begin{array}{l}\text { - Turning off the pumps and contactors } \\
\text { achieves a quick shutdown. But } \\
\text { stripping of the Cs from the organic } \\
\text { would take several hours for a long } \\
\text { term shutdown. } \\
\text { - Stripping of Cs may need to be } \\
\text { performed as part of a shutdown } \\
\text { operation }\end{array}$ & $\begin{array}{l}\text { - Simple turning off the pumps } \\
\text { achieves the quick shutdown, but } \\
\text { rinse and elution of }{ }^{137} \mathrm{Cs} \text { from resin } \\
\text { columns maybe required for long } \\
\text { term shutdown } \\
\text { - Elution of Cs may need to be } \\
\text { performed as part of a shutdown } \\
\text { operation }\end{array}$ \\
\hline & $\begin{array}{l}1.1 .6 \\
\text { Process that does not } \\
\text { create a new or } \\
\text { exacerbate an existing } \\
\text { Tank Farm hazard is } \\
\text { preferred to one that } \\
\text { does }\end{array}$ & $\begin{array}{l}\text { The potential for solids in the FC } \\
\text { return stream (or in the tank as the } \\
\text { solution cools) will need further } \\
\text { evaluation. No other potential were } \\
\text { identified which exacerbate tank } \\
\text { farm hazard accidental scenarios. }\end{array}$ & $\begin{array}{l}\text { Potential exists for one tank farm } \\
\text { hazard accidental scenarios - mixing } \\
\text { of incompatible chemicals. }\end{array}$ & $\begin{array}{l}\text { Potential exists for one tank farm } \\
\text { hazard accidental scenarios - mixing } \\
\text { of incompatible chemicals. }\end{array}$ \\
\hline & $\begin{array}{l}1.1 .7 \\
\text { Less fire hazard (e.g. } \\
\text { less quantity of } \\
\text { combustibles, including } \\
\text { flammable gas, less } \\
\text { flammable combustibles, } \\
\text { etc.) }\end{array}$ & $\begin{array}{l}\text { - Does not use combustible material. } \\
\text { - Process is susceptible to forming } \\
\text { hydrogen gas due to radiolysis. }\end{array}$ & $\begin{array}{l}\text { - Use of organic solvents with a low } \\
\text { flash point of } 62^{\circ} \mathrm{C} \text { (Isopar L) } \\
\text { elevates fire safety concern. } \\
\text { - Organic susceptible to forming } \\
\text { hydrogen gas due to radiolysis - } \\
\text { postulated accident }\end{array}$ & $\begin{array}{l}\text { - Process is susceptible to forming } \\
\text { hydrogen gas due to radiolysis. } \\
\text { - Various chemicals used in the } \\
\text { process may generate heat if mixed } \\
\text { improperly. } \\
\text { - Decay heat on resin column increases } \\
\text { potential for fire, but water-cooled } \\
\text { jacket will be integrated into IX } \\
\text { column design }\end{array}$ \\
\hline & $\begin{array}{l}1.1 .8 \\
\text { Reactive Chemicals - } \\
\text { Process with less } \\
\text { reactive chemicals } \\
\text { (reactivity) is better }\end{array}$ & $\begin{array}{l}\text { - Only chemical that may be used is } \\
\text { nitric acid (low concentration) for } \\
\text { cleaning. } \\
\text { - Lowest chemical reactivity. }\end{array}$ & $\begin{array}{l}\text { - Uses caustic, nitric acid and } 4 \\
\text { different organic solvents } \\
\text { components. Organic solvents have } \\
\text { negligible or no chemical reactivity. } \\
\text { - Interactions of nitric acid with caustic } \\
\text { solutions and strong acids with } \\
\text { organic solvents should be carefully } \\
\text { monitored and controlled. } \\
\text { - More concentration and higher } \\
\text { quantity of hazardous chemicals, e.g., } \\
\text { nitric acid in IPS }\end{array}$ & $\begin{array}{l}\text { - Uses caustic, nitric acid and sRF } \\
\text { organic resins. } \\
\text { - Interactions of nitric acid with } \\
\text { caustic solutions should be carefully } \\
\text { monitored and controlled. } \\
\text { - More concentration and higher } \\
\text { quantity of hazardous chemicals, } \\
\text { e.g., nitric acid in IPS }\end{array}$ \\
\hline
\end{tabular}


Table B-1 - Cesium Separation Technology Assessment Summary Matrix

\begin{tabular}{|c|c|c|c|c|}
\hline Criteria & $\begin{array}{c}\text { Measures and } \\
\text { Definitions }\end{array}$ & Fractional Crystallization (FC) & $\begin{array}{c}\text { Caustic-Side Solvent Extraction } \\
\text { (CSSX) }\end{array}$ & Ion Exchange with sRF (IX-sRF) \\
\hline 1.2 Criticality Safety & $\begin{array}{l}1.2 .1 \\
\text { A Process that is } \\
\text { inherently sub-critical is } \\
\text { preferred over a process } \\
\text { that relies on criticality } \\
\text { controls }\end{array}$ & $\begin{array}{l}\text { FC process is sub-critical under } \\
\text { expected conditions as it does not } \\
\text { hold up enough feed volume to } \\
\text { approach the critical mass limit in } \\
\text { any condition. } \\
\text { - FC does not change the result of tank } \\
\text { farm DSA evaluation. }\end{array}$ & $\begin{array}{l}\bullet \text { CSSX process is sub-critical under } \\
\text { expected conditions as it does not } \\
\text { hold up enough feed volume to } \\
\text { approach the critical mass limit in any } \\
\text { condition. } \\
\text { - CSSX does not change the result of } \\
\text { tank farm DSA evaluation. }\end{array}$ & $\begin{array}{l}\text { - IX-sRF process is sub-critical under } \\
\text { expected conditions as it does not } \\
\text { hold up enough feed volume to } \\
\text { approach the critical mass limit in } \\
\text { any condition. } \\
\text { - IX-sRF does not change the result of } \\
\text { tank farm DSA evaluation. }\end{array}$ \\
\hline $\begin{array}{l}1.3 \text { Industrial Safety } \\
\text { and Hygiene }\end{array}$ & $\begin{array}{l}\text { 1.3.1 } \\
\text { Less hazards/less severe } \\
\text { hazardous is better (e.g., } \\
\text { less hazardous } \\
\text { chemicals, less noise, } \\
\text { less hot surfaces, less } \\
\text { rotating equipment, less } \\
\text { confined spaces, etc.) }\end{array}$ & $\begin{array}{l}\text { - Large product tanks }(8,600-32,000 \\
\text { gals) along with pumps, heat } \\
\text { exchangers, reboilers, and } \\
\text { condensers are located in below- } \\
\text { grade areas of confined space in a } \\
\text { radiation zone. } \\
\text { - Two crystallizers are tall ( } 30 \mathrm{ft}) \\
\text { requiring a ladder and elevated } \\
\text { walkways for access. } \\
\text { - Does not add chemicals for } \\
\text { processing. }\end{array}$ & $\begin{array}{l}\text { - Large product tanks }(11,500-45,000 \\
\text { gas) along with contactors and } \\
\text { associated pumps and heat exchangers } \\
\text { are located below grade areas of } \\
\text { confined space in a radiation zone. } \\
\text { - Uses organic solvent, } \mathrm{NaOH}, \mathrm{NaNO}_{2} \\
\text { and } \mathrm{HNO}_{3} \text { requiring chemical area } \\
\text { and handling. }\end{array}$ & $\begin{array}{l}\text { - Large product tanks }(11,500-45,000 \\
\text { gas) along with contactors and } \\
\text { associated pumps and heat } \\
\text { exchangers are located below grade } \\
\text { areas of confined space in a radiation } \\
\text { zone. } \\
\text { - Uses ion exchange resin, } \mathrm{NaOH}, \\
\text { NaNO2 and HNO3 requiring } \\
\text { chemical area and handling. }\end{array}$ \\
\hline \multirow[t]{2}{*}{$\begin{array}{l}2 \text { REGULATORY/ } \\
\text { STAKEHOLDER } \\
\text { ACCEPTANCE } \\
2.1 \text { Achieve Tribal } \\
\text { Nations/ } \\
\text { stakeholders' } \\
\text { acceptance }\end{array}$} & $\begin{array}{l}2.1 .1 \\
\text { Early waste treatment } \\
\text { enabled }\end{array}$ & $\begin{array}{l}\text { - Early waste pretreatment schedule } \\
\text { expectation can be met. } \\
\text { Technological maturity assessment is } \\
\text { needed to confirm this. } \\
\text { - Some additional demonstration and } \\
\text { verification work is required for } \\
\text { Hanford use. } \\
\text { - Based on familiarity with evaporator } \\
\text { technology - stakeholders are less } \\
\text { likely to support implementation of a } \\
\text { somewhat analogous technology } \\
\end{array}$ & $\begin{array}{l}\text {-Early waste pretreatment schedule } \\
\text { expectation can be met. } \\
\text { Technological maturity assessment is } \\
\text { needed to confirm this. } \\
\text { - Some additional demonstration and } \\
\text { verification work is required for } \\
\text { Hanford use. } \\
\text { - New technology to Hanford - } \\
\text { stakeholders are least likely to support } \\
\text { implementation of a less familiar } \\
\text { technology }\end{array}$ & $\begin{array}{l}\text { - Early waste pretreatment schedule } \\
\text { expectation can be met. } \\
\text { Technological maturity assessment } \\
\text { is needed to confirm this. } \\
\text { - Limited dem onstration and } \\
\text { verification work is required. } \\
\text { - Based on familiarity with past } \\
\text { Hanford separations and WTP based } \\
\text { technology -stakeholders are most } \\
\text { likely to support implementation of a } \\
\text { more familiar technology }\end{array}$ \\
\hline & $\begin{array}{l}2.1 .2 \\
\text { Land usage (more } \\
\text { contaminated ground) }\end{array}$ & $\begin{array}{l}\text { - Process Vault/Building footprint is } \\
5699 \mathrm{ft}^{2} \text { (with RMF) and } 5963 \mathrm{ft}^{2} \\
\text { (with CFF). }\end{array}$ & $\begin{array}{l}\text { - Process Vault/Building footprint is } \\
6016 \mathrm{ft}^{2} \text { (with RMF) and } 6628 \mathrm{ft}^{2} \\
\text { (with CFF). }\end{array}$ & $\begin{array}{l}\text { - Process Vault/Building footprint is } \\
4032 \mathrm{ft}^{2} \text { (with RMF) and } 4610 \mathrm{ft}^{2} \\
\text { (with CFF). }\end{array}$ \\
\hline
\end{tabular}


RPP-RPT-38057, Rev. 0

Table B-1 - Cesium Separation Technology Assessment Summary Matrix

\begin{tabular}{|c|c|c|c|c|}
\hline Criteria & $\begin{array}{c}\text { Measures and } \\
\text { Definitions }\end{array}$ & Fractional Crystallization (FC) & $\begin{array}{l}\text { Caustic-Side Solvent Extraction } \\
\text { (CSSX) }\end{array}$ & Ion Exchange with sRF (IX-sRF) \\
\hline \multirow[t]{3}{*}{$\begin{array}{l}2.2 \text { Achieve regulators' } \\
\text { acceptance }\end{array}$} & $\begin{array}{l}2.2 .1 \\
\text { Compliance with } \\
\text { applicable regulations } \\
\text { (RCRA, NEPA/SEPA, } \\
\text { NESHAPS, NPDES, } \\
\text { CAA, DOE Orders) }\end{array}$ & $\begin{array}{l}\text { - Can be permitted in } 28-33 \text { months } \\
\text { with some additional process } \\
\text { demonstration work. } \\
\text { - Depends on TC\&WM EIS and ROD } \\
\text { being completed by January } 2010 \text {. } \\
\text { - RCRA Part B Application required. } \\
\text { - Three notices of construction } \\
\text { required. }\end{array}$ & $\begin{array}{l}\text { - Can be permitted in } 28-33 \text { months } \\
\text { with some additional process } \\
\text { demonstration work. } \\
\text { - Depends on TC\&WM EIS and ROD } \\
\text { being completed by January } 2010 \text {. } \\
\text { - RCRA Part B Application required. } \\
\text { - Three notices of construction } \\
\text { required. }\end{array}$ & $\begin{array}{l}\text { - Can be permitted in } 28-33 \text { months } \\
\text { with some additional process } \\
\text { demonstration work. } \\
\text { - Depends on TC\&WM EIS and ROD } \\
\text { being completed by January } 2010 \text {. } \\
\text { - RCRA Part B Application required. } \\
\text { Three notices of construction } \\
\text { required. }\end{array}$ \\
\hline & $\begin{array}{l}2.2 .2 \\
\text { Impact to Disposal } \\
\text { System Performance }\end{array}$ & $\begin{array}{l}\text { - Further investigation of potential } \\
\text { COPC concern for secondary waste } \\
\text { disposal system is required. } \\
\text { - The current WTP Project } \\
\text { commissioning approach will support } \\
\text { commissioning and operation of the } \\
\text { LAW processing facility, without the } \\
\text { support of the Pretreatment facility. } \\
\text { - FC will remove Tc from LAW feed; } \\
\text { a substantial positive for FC }\end{array}$ & $\begin{array}{l}\text { - Further investigation of potential } \\
\text { COPC concern for secondary waste } \\
\text { disposal system is required. } \\
\text { - The current WTP Project } \\
\text { commissioning approach will support } \\
\text { commissioning and operation of the } \\
\text { LAW processing facility, without the } \\
\text { support of the Pretreatment facility. }\end{array}$ & $\begin{array}{l}\text { - Further investigation of potential } \\
\text { COPC concern for secondary waste } \\
\text { disposal system is required. } \\
\text { - The current WTP Project } \\
\text { commissioning approach will } \\
\text { support commissioning and } \\
\text { operation of the LAW processing } \\
\text { facility, without the support of the } \\
\text { Pretreatment facility. }\end{array}$ \\
\hline & $\begin{array}{l}2.2 .3 \\
\text { Secondary Waste Form } \\
\text { and Quantity }\end{array}$ & $\begin{array}{l}\text { - Generates 7,256,143 L (1.9 million } \\
\text { gallons) of liquid effluent for } \\
\text { disposal at ETF. }\end{array}$ & $\begin{array}{l}\bullet \text { Generates } 680-1,475 \mathrm{~L}(180-390 \\
\text { gallons) of liquid organic solvent per } \\
\text { year for disposal. }\end{array}$ & $\begin{array}{l}\text { - Generates } 4,535 \mathrm{~kg}(10,000 \mathrm{lbs}) \text { of } \\
\text { spent resin for disposal. }\end{array}$ \\
\hline
\end{tabular}


RPP-RPT-38057, Rev. 0

Table B-1 - Cesium Separation Technology Assessment Summary Matrix

\begin{tabular}{|c|c|c|c|c|}
\hline Criteria & $\begin{array}{l}\text { Measures and } \\
\text { Definitions }\end{array}$ & Fractional Crystallization (FC) & $\begin{array}{l}\text { Caustic-Side Solvent Extraction } \\
\text { (CSSX) }\end{array}$ & Ion Exchange with sRF (IX-sRF) \\
\hline & $\begin{array}{l}2.2 .4 \\
\text { Potential impacts to } \\
\text { other permitted facilities }\end{array}$ & $\begin{array}{l}\text { - Secondary waste to ETF will meet } \\
\text { Waste Acceptance Criteria. } \\
\text { - Permit modification for IDF will be } \\
\text { needed sooner than anticipated } \\
\text { (allows disposal of LAW glass) }\end{array}$ & $\begin{array}{l}\text { - Does not generate secondary waste for } \\
\text { ETF. } \\
\text {-Permafix is the permitted facility for } \\
\text { disposal of organic. If it is } \\
\text { determined that their permit needs to } \\
\text { be modified to accept other waste } \\
\text { codes, it would likely be a class } 2 \text { or } \\
\text { class } 3 \text { modification of the permit and } \\
\text { require a minimum of } 6 \text { months and } \\
\text { up to } 2 \text { years for a class } 3 \text {. } \\
\text { - The WTP permit does not prohibits } \\
\text { organics (only Do01 \& Do03 waste } \\
\text { codes are called out in the permit). } \\
\text { The extent to which destruction of } \\
\text { organics occurs and how they would } \\
\text { impact the DRE (destructive removal } \\
\text { efficiency) would need to be } \\
\text { determined. } \\
\text {-Permit modification for IDF will be } \\
\text { needed sooner than anticipated } \\
\text { (allows disposal of LAW glass) }\end{array}$ & $\begin{array}{l}\text { - Does not generate secondary waste } \\
\text { for ETF. } \\
\text { - Permit mod for IDF to accept spent } \\
\text { resins } \\
\text { - Permit modification for IDF will be } \\
\text { needed sooner than anticipated } \\
\text { (allows disposal of LAW glass) }\end{array}$ \\
\hline \multirow[t]{2}{*}{$\begin{array}{l}3 \text { TECHNICAL } \\
\text { MATURITY } \\
\text { FLEXIBILITY } \\
3.1 \text { Technology } \\
\text { Readiness Level }\end{array}$} & $\begin{array}{l}3.1 .1 \\
\text { TRL Number }\end{array}$ & $\begin{array}{l}\text { - TRL number is } 4 \text { - this TRL number } \\
\text { is based on the technical and } \\
\text { programmatic work that was done in } \\
\text { support of SST wastes in } 200 \mathrm{~W} \text {. } \\
\text { May } 2008 \text { review of original } \\
\text { assessment found that original work } \\
\text { was sufficiently valid to maintain } \\
\text { TRL \# of } 4 \text {. } \\
\text { - Original assessment was based on } \\
\text { SST saltcake feeds, rather than DST } \\
\text { supernate feeds identified for IPS }\end{array}$ & $\begin{array}{l}\text { TRL number is } 3 \\
\text { - Lab testing with simulants and } \\
\text { modeling needed } \\
\text {-Potassium could be an issue }\end{array}$ & $\begin{array}{l}\text { - TRL number is } 3 \\
\text { - Cs separation demonstrated with real } \\
\text { waste } \\
\text { - Equipment optimization is primarily } \\
\text { need (engineering, not development) }\end{array}$ \\
\hline & $\begin{array}{l}3.1 .2 \\
\text { Effort to mature } \\
\text { technology (cost and } \\
\text { schedule) }\end{array}$ & $\begin{array}{l}\text { - ROM cost and schedule to mature } \\
\text { technology is } \$ 3.0 \mathrm{M} \text { over } 30 \text { months. }\end{array}$ & $\begin{array}{l}\text { - ROM cost and schedule to mature } \\
\text { technology is } \$ 4.5 \mathrm{M} \text { over } 36 \text { months. }\end{array}$ & $\begin{array}{l}\text { - ROM cost and schedule to mature } \\
\text { technology is } \$ 3.5 \mathrm{M} \text { over } 33 \\
\text { months. }\end{array}$ \\
\hline
\end{tabular}


RPP-RPT-38057, Rev. 0

Table B-1 - Cesium Separation Technology Assessment Summary Matrix

\begin{tabular}{|c|c|c|c|c|}
\hline Criteria & $\begin{array}{l}\text { Measures and } \\
\text { Definitions }\end{array}$ & Fractional Crystallization (FC) & $\begin{array}{l}\text { Caustic-Side Solvent Extraction } \\
\text { (CSSX) }\end{array}$ & Ion Exchange with sRF (IX-sRF) \\
\hline & $\begin{array}{l}3.1 .3 \\
\text { Probability of Success }\end{array}$ & $\begin{array}{l}\text { - Probability of success for maturing } \\
\text { technology is "High". }\end{array}$ & $\begin{array}{l}\text {-Probability of success for maturing } \\
\text { technology is "Medium". (waste } \\
\text { foaming issue was rated as a High } \\
\text { risk, even though it had marginal } \\
\text { probability of occurring; entrainment } \\
\text { could also be an issue) }\end{array}$ & $\begin{array}{l}\text { - Probability of success for maturing } \\
\text { technology is "High". }\end{array}$ \\
\hline \multirow[t]{6}{*}{$\begin{array}{l}3.2 \text { Process Flexibility } \\
\text { and robustness }\end{array}$} & $\begin{array}{l}3.2 .1 \\
\text { Ability to process a } \\
\text { variety of feeds }\end{array}$ & $\begin{array}{l}\text { - Highly sensitive to analytes in waste } \\
\text { feed } \\
\text { - Sensitive to a variety of physical } \\
\text { parameters }\end{array}$ & $\begin{array}{l}\text { - Process is potentially sensitive to } \\
\text { potassium content of IPS candidate } \\
\text { feeds }\end{array}$ & $\begin{array}{l}\text { - Selected resin has been demonstrated } \\
\text { to meet Cs removal rates for IPS } \\
\text { candidate feeds }\end{array}$ \\
\hline & $\begin{array}{l}3.2 .2 \\
\text { Ability to adjust process } \\
\text { rate - turn up/ turn down }\end{array}$ & $\begin{array}{l}\text { - Demonstrates "High" level of } \\
\text { flexibility to adjust process rates. }\end{array}$ & $\begin{array}{l}\text { - Demonstrates "Medium" level of } \\
\text { flexibility to adjust process rates. }\end{array}$ & $\begin{array}{l}\text { - Demonstrates "Medium" level of } \\
\text { flexibility to adjust process rates. }\end{array}$ \\
\hline & $\begin{array}{l}3.2 .3 \\
\text { Flexibility to modify } \\
\text { product }\end{array}$ & $\begin{array}{l}\text { "High" product flexibility with } 15 \\
\text { degrees of freedom. -2stages }+\end{array}$ & $\begin{array}{l}\text { "Medium" product flexibility with } 10 \\
\text { degrees of freedom. }\end{array}$ & $\begin{array}{l}\text { " Medium" product flexibility with } 10 \\
\text { degrees of freedom. }\end{array}$ \\
\hline & $\begin{array}{l}3.2 .4 \\
\text { Ability to expand }\end{array}$ & $\begin{array}{l}\text { - Capacity increase would require } \\
\text { significant equipment size increases } \\
\text { and footprint modifications }\end{array}$ & $\begin{array}{l}\text { Practical volume increases would } \\
\text { require resizing of contactors or } \\
\text { installation of parallel lines }\end{array}$ & $\begin{array}{l}\text { - Capacity increase would require } \\
\text { moderate size increases and footprint } \\
\text { modifications }\end{array}$ \\
\hline & $\begin{array}{l}3.2 .5 \\
\text { Recover from out of } \\
\text { spec product - }\end{array}$ & $\begin{array}{l}\text { - System would require minor tank } \\
\text { storage changes to handle out-of-spec } \\
\text { product while recycling }\end{array}$ & $\begin{array}{l}\text { - Installation of recycle piping would be } \\
\text { required at an } \mathrm{ROM} \text { cost of } \angle \$ 5 \mathrm{M}\end{array}$ & $\begin{array}{l}\text { - System would require minor tank } \\
\text { storage changes to handle out-of- } \\
\text { spec product while recycling }\end{array}$ \\
\hline & $\begin{array}{l}3.2 .6 \\
\text { Technology applicability } \\
\text { to other DOE complex } \\
\text { projects - revisit in } \\
\text { programmatic aspects } \\
\text { evaluation }\end{array}$ & $\begin{array}{l}\text { " } N o \text { " applicability to other DOE } \\
\text { complex projects. }\end{array}$ & $\begin{array}{l}\text { " "High" applicability to other DOE } \\
\text { complex projects. }\end{array}$ & $\begin{array}{l}\text { - "High" applicability to other DOE } \\
\text { complex projects. }\end{array}$ \\
\hline \multirow[t]{2}{*}{$\begin{array}{l}4 \text { OPERABILITY AND } \\
\text { MAINTAINABILITY } \\
4.1 \text { Ease of Process } \\
\text { control and } \\
\text { operation }\end{array}$} & $\begin{array}{l}\text { 4.1.1 } \\
\text { Minimize number and } \\
\text { frequency of } \\
\text { surveillances }\end{array}$ & $\begin{array}{l}\text { - } 58 \text { process parameters and } 11 \text { sump } \\
\text { leak detectors requiring routine } \\
\text { measurements and recordings. }\end{array}$ & $\begin{array}{l}\text { - } 38 \text { process parameters, } 20 \text { sump leak } \\
\text { detectors and } 98 \text { other equipment } \\
\text { related data points requiring routine } \\
\text { measurements and recordings. }\end{array}$ & $\begin{array}{l}\text { - } 26 \text { process parameters and } 18 \text { sump } \\
\text { leak detectors requiring routine } \\
\text { measurements and recordings. }\end{array}$ \\
\hline & \begin{tabular}{|l|}
4.1 .2 \\
Minimize number of \\
people to operate
\end{tabular} & - Estimated 10 people to operate. & - Estimated 11 people to operate. & - Estimated 10 people to operate. \\
\hline
\end{tabular}


RPP-RPT-38057, Rev. 0

Table B-1 - Cesium Separation Technology Assessment Summary Matrix

\begin{tabular}{|c|c|c|c|c|}
\hline Criteria & $\begin{array}{l}\text { Measures and } \\
\text { Definitions }\end{array}$ & Fractional Crystallization (FC) & $\begin{array}{l}\text { Caustic-Side Solvent Extraction } \\
\text { (CSSX) }\end{array}$ & Ion Exchange with sRF (IX-sRF) \\
\hline & $\begin{array}{l}4.1 .3 \\
\text { Ease of startup and } \\
\text { shutdown }\end{array}$ & $\begin{array}{l}\text { - Startup and shut down has medium } \\
\text { complexity among these three } \\
\text { systems. }\end{array}$ & $\begin{array}{l}\text { - Startup and shut down is the most } \\
\text { time consuming and complex among } \\
\text { these three systems. }\end{array}$ & $\begin{array}{l}\text { - Startup and shut down is relatively } \\
\text { simple with the lowest complexity } \\
\text { among these three systems. }\end{array}$ \\
\hline & $\begin{array}{l}4.1 .4 \\
\text { Minimize system } \\
\text { complexity }\end{array}$ & $\begin{array}{l}\text { - System complexity is moderate due } \\
\text { to basic evaporation equipment with } \\
\text { specialized control functions. }\end{array}$ & $\begin{array}{l}\text { - System complexity is very high with } \\
85 \text { active components with associated } \\
\text { instrumentation. System and process } \\
\text { flow sheets are highly complex with } \\
\text { potential for more process upsets. }\end{array}$ & $\begin{array}{l}\text { - System complexity is considered to } \\
\text { be low based on passive nature of } \\
\text { resin columns. }\end{array}$ \\
\hline & $\begin{array}{l}4.1 .5 \\
\text { Minimize number of } \\
\text { chemicals needed }\end{array}$ & $\begin{array}{l}\text { - No chemicals used in the basic } \\
\text { system operation. }\end{array}$ & $\begin{array}{l}- \text { In addition to } \mathrm{NaOH}, \mathrm{NaNO}_{2} \text {, and } \\
\mathrm{HNO}_{3} \text {, four other organic chemicals } \\
\text { are used in the process. }\end{array}$ & $\begin{array}{l}\text { - Three chemicals, } \mathrm{NaOH}, \mathrm{NaNO}_{2} \text {, and } \\
\mathrm{HNO}_{3} \text { are used in the process. }\end{array}$ \\
\hline & $\begin{array}{l}4.1 .6 \\
\text { Minimize number of } \\
\text { process and regulatory } \\
\text { samples }\end{array}$ & $\begin{array}{l}\text { - Process sampling needs include feed } \\
\text { and product streams and steam } \\
\text { condensate. Batch sampling of liquid } \\
\text { effluent stream going to ETF will be } \\
\text { required. }\end{array}$ & $\begin{array}{l}\text { Process sampling needs is anticipated } \\
\text { for feed and product streams. In } \\
\text { addition, aqueous and organic streams } \\
\text { from contactors, process chemicals } \\
\text { will be required on a regular basis. } \\
\text { Spent solvent will be sampled on a } \\
\text { batch basis to meet regulatory } \\
\text { disposal requirements. }\end{array}$ & $\begin{array}{l}\text { Process sampling needs is anticipated } \\
\text { for feed and product streams. } \\
\text { Aqueous make ups should be } \\
\text { sampled on a regular basis. Spent } \\
\text { resin sampling will be required on a } \\
\text { batch basis to assure disposal } \\
\text { requirement conformance. }\end{array}$ \\
\hline & $\begin{array}{l}4.1 .7 \\
\text { Batch versus continuous }\end{array}$ & $\begin{array}{l}\text { - Operates on a semi-continuous or } \\
\text { campaign basis. }\end{array}$ & - Operates on a continuous basis. & - Operates only on a batch basis. \\
\hline & $\begin{array}{l}4.1 .8 \\
\text { Ease of entry and exit } \\
\text { from standby }\end{array}$ & $\begin{array}{l}\text { - Minor impact for standby restart } \\
\text { activities. }\end{array}$ & $\begin{array}{l}\text { - Significant operational impacts for } \\
\text { any shutdown or standby condition to } \\
\text { restart activities. }\end{array}$ & $\begin{array}{l}\text { - Minimal impacts for a short time } \\
\text { standby restart activities. }\end{array}$ \\
\hline & $\begin{array}{l}4.1 .9 \\
\text { Wide operating margin }\end{array}$ & $\begin{array}{l}\text { - Can be applied to wide range of feed } \\
\text { containing various chemicals. } \\
\text { - Relatively tight range of temperature } \\
\text { and pressure required for crystal } \\
\text { formation }\end{array}$ & $\begin{array}{l}\text { Does not have a wide operating range } \\
\text { for most flow sheet parameters with } \\
\text { the exception of the washing and } \\
\text { scrubbing functions. } \\
\text { - Aqueous/organic ratio is critical and } \\
\text { needs to be tightly controlled }\end{array}$ & $\begin{array}{l}\text { - Narrow range of application, based } \\
\text { on Na concentration } \\
\text { - Relatively forgiving process based on } \\
\text { temperature range. }\end{array}$ \\
\hline & $\begin{array}{l}4.1 .10 \\
\text { Complexity of transfers } \\
\text { to, from and within Tank } \\
\text { Farms }\end{array}$ & $\begin{array}{l}\text { - Effluent stream transfer to ETF for } \\
\text { final disposal. } \\
\text { - Return stream to DSTs }\end{array}$ & $\begin{array}{l}\text { - Standard tank farm transfers (requires } \\
\text { no special equipment or processes to } \\
\text { transfers). } \\
\text { - Return stream to DSTs }\end{array}$ & $\begin{array}{l}\text { - No special or additional tank waste } \\
\text { transfer anticipated. } \\
\text { - Return stream to DSTs }\end{array}$ \\
\hline
\end{tabular}


RPP-RPT-38057, Rev. 0

Table B-1 - Cesium Separation Technology Assessment Summary Matrix

\begin{tabular}{|c|c|c|c|c|}
\hline Criteria & $\begin{array}{l}\text { Measures and } \\
\text { Definitions }\end{array}$ & Fractional Crystallization (FC) & $\begin{array}{l}\text { Caustic-Side Solvent Extraction } \\
\text { (CSSX) }\end{array}$ & Ion Exchange with sRF (IX-sRF) \\
\hline $4.2 A L A R A$ & $\begin{array}{l}4.2 .1 \\
\text { Less required contact } \\
\text { maintenance is better, } \\
\text { etc. }\end{array}$ & $\begin{array}{l}\text { - Estimated process related } \\
\text { components requiring hands-on or } \\
\text { contact maintenance are: One waste } \\
\text { feed pump, } 2 \text { centrifuges, } 15 \text { process } \\
\text { pumps, undetermined numbers of } \\
\text { flow meters, and flow control valves. } \\
\text { - Has medium number of components } \\
\text { that may require contact } \\
\text { maintenance. }\end{array}$ & $\begin{array}{l}\text { - Estimated process related components } \\
\text { requiring hands-on or contact } \\
\text { maintenance are: One waste feed } \\
\text { pump, } 41 \text { contactors; } 7 \text { primary } \\
\text { process pumps, undetermined } \\
\text { numbers of flow meters, and flow } \\
\text { control valves; seven transfer pumps } \\
\text { associated with aqueous chemical } \\
\text { make up area. } \\
\text { - Has highest number of components } \\
\text { that may require contact maintenance. }\end{array}$ & $\begin{array}{l}\text { - Estimated process related } \\
\text { components requiring hands-on or } \\
\text { contact maintenance are: One waste } \\
\text { feed pump, } 2 \text { ion exchange columns; } \\
13 \text { process pumps, undetermined } \\
\text { numbers of flow meters, and flow } \\
\text { control valves. } \\
\text { - Has lowest number of components } \\
\text { that may require contact } \\
\text { maintenance. }\end{array}$ \\
\hline \multirow[t]{2}{*}{4.3 Reliability } & $\begin{array}{l}4.3 .1 \\
\text { Number of active } \\
\text { components }\end{array}$ & $\begin{array}{l}\text { - System has } 21 \text { active components } \\
\text { consisting of pumps, centrifuges, } \\
\text { chilled water skids, and building } \\
\text { ventilation system. }\end{array}$ & $\begin{array}{l}\text { - System has } 60 \text { active components } \\
\text { consisting of pumps and centrifugal } \\
\text { contactors, and building ventilation } \\
\text { system. }\end{array}$ & $\begin{array}{l}\text { - System has } 14 \text { active components } \\
\text { consisting of pumps and building } \\
\text { ventilation system. }\end{array}$ \\
\hline & $\begin{array}{l}4.3 .2 \\
\text { Reliability of analogous } \\
\text { systems }\end{array}$ & $\begin{array}{l}\text { - 242-A Evaporators provides strong } \\
\text { analogous reliability data support. }\end{array}$ & $\begin{array}{l}\text { - The use of centrifugal contactors has } \\
\text { been successful at SRS. } \\
\text { - }\end{array}$ & $\begin{array}{l}\text { - Ion exchange operation does provide } \\
\text { some improved reliability, but sRF } \\
\text { resin reliability data is not available. } \\
\text { - Large-scale IX has been operated } \\
\text { successfully at Hanford for many } \\
\text { years, e.g., B-Plant separations of Cs } \\
\text { and Sr }\end{array}$ \\
\hline \multirow[t]{3}{*}{$\begin{array}{l}4.4 \text { Ease and frequency } \\
\text { of maintenance }\end{array}$} & $\begin{array}{l}4.4 .1 \\
\text { Minimize number of } \\
\text { support systems }\end{array}$ & $\begin{array}{l}\text { - Requires } 3 \text { standard services of air, } \\
\text { water, and cooling water. } \\
\text { - Requires steam to be provided } \\
\text { - Requires } 1 \text { chemical support service. }\end{array}$ & $\begin{array}{l}\text { - Requires } 3 \text { standard services of air, } \\
\text { water and cooling water. } \\
\text { - Requires six chemical support } \\
\text { services. }\end{array}$ & $\begin{array}{l}\text { - Requires } 3 \text { standard services of air, } \\
\text { water and cooling water. } \\
\text { - Requires five chemical support } \\
\text { services. }\end{array}$ \\
\hline & $\begin{array}{l}4.4 .2 \\
\text { Minimize number and } \\
\text { frequency of PM's }\end{array}$ & $\begin{array}{l}\text { - Moderate level of PMs required due } \\
\text { to the large number of rotating } \\
\text { components, and necessary piping } \\
\text { and control system. }\end{array}$ & $\begin{array}{l}\text { Extensive level of PMs required due } \\
\text { to the large number of rotating } \\
\text { components, and necessary piping and } \\
\text { control system. }\end{array}$ & $\begin{array}{l}\text { - Minimal level of PMs required due to } \\
\text { the passive operation of a majority of } \\
\text { the technology, and low number of } \\
\text { process components required. }\end{array}$ \\
\hline & $\begin{array}{l}4.4 .3 \\
\text { Minimize maintenance } \\
\text { in zone entries }\end{array}$ & $\begin{array}{l}\text { - Moderate amount of equipment } \\
\text { requiring maintenance in-zone. }\end{array}$ & $\begin{array}{l}\text { Extensive amount of equipment } \\
\text { requiring maintenance in-zone. }\end{array}$ & $\begin{array}{l}\text { - Moderate amount of equipment } \\
\text { requiring maintenance in-zone. } \\
\text { - Fewer in-zone maintenance items; } \\
\text { most of equipment, e.g., pumps, are } \\
\text { located in cold chemical area }\end{array}$ \\
\hline
\end{tabular}


RPP-RPT-38057, Rev. 0

Table B-1 - Cesium Separation Technology Assessment Summary Matrix

\begin{tabular}{|c|c|c|c|c|}
\hline Criteria & $\begin{array}{l}\text { Measures and } \\
\text { Definitions }\end{array}$ & Fractional Crystallization (FC) & $\begin{array}{l}\text { Caustic-Side Solvent Extraction } \\
\text { (CSSX) }\end{array}$ & Ion Exchange with sRF (IX-sRF) \\
\hline & $\begin{array}{l}4.4 .4 \\
\text { Minimize specialized } \\
\text { equipment and parts }\end{array}$ & $\begin{array}{l}\text { - Uses commercially available } \\
\text { components }\end{array}$ & $\begin{array}{l}\text { - Uses specialized components which } \\
\text { may limit the availability of } \\
\text { components and parts. }\end{array}$ & $\begin{array}{l}\text { - Uses commercially available } \\
\text { components } \\
\text { - Assumes external jacketed cooling to } \\
\text { IX column }\end{array}$ \\
\hline & $\begin{array}{l}4.4 .5 \\
\text { Minimize tank entries - } \\
\text { N/A }\end{array}$ & $\begin{array}{l}\text { - No tank entries are required for this } \\
\text { technology. }\end{array}$ & $\begin{array}{l}\text { No tank entries are required for this } \\
\text { technology. }\end{array}$ & $\begin{array}{l}\text { - No tank entries are required for this } \\
\text { technology. }\end{array}$ \\
\hline \multirow[t]{3}{*}{$\begin{array}{l}4.5 \text { Ease of } \\
\text { Implementation }\end{array}$} & $\begin{array}{l}4.5 .1 \\
\text { Ease of training }\end{array}$ & $\begin{array}{l}\text { - Above average amount of training is } \\
\text { anticipated due to large number of } \\
\text { components and complex process } \\
\text { control. }\end{array}$ & $\begin{array}{l}\text { - Extensive amount of training is } \\
\text { anticipated due to large number of } \\
\text { components and complex process } \\
\text { control. }\end{array}$ & $\begin{array}{l}\text { - Nominal amount of training is } \\
\text { anticipated due to small number of } \\
\text { components and simpler process } \\
\text { control. }\end{array}$ \\
\hline & $\begin{array}{l}4.5 .2 \\
\text { Complexity of } \\
\text { procedures }\end{array}$ & $\begin{array}{l}\text { Above average complexity in } \\
\text { procedures. }\end{array}$ & -Extensive complexity in procedures. & - Nominal complex procedures. \\
\hline & $\begin{array}{l}4.5 .3 \\
\text { Similar to other process } \\
\text { facilities on site }\end{array}$ & $\begin{array}{l}\text { - Technology is similar to evaporator } \\
\text { system with familiarity at Hanford. }\end{array}$ & $\begin{array}{l}\text { - Technology is not used at Hanford, } \\
\text { but is being implemented at SRS. }\end{array}$ & $\begin{array}{l}\text { Technology is similar to other ion } \\
\text { exchange systems used at Hanford } \\
\text { and will be implemented at } \\
\text { pretreatment facility of the WTP } \\
\text { project. }\end{array}$ \\
\hline \multirow[t]{2}{*}{$\begin{array}{l}\text { 4.6 Liquid/solid } \\
\text { secondary waste }\end{array}$} & $\begin{array}{l}4.6 .1 \\
\text { Waste handling } \\
\text { compatible with existing } \\
\text { systems as defined by } \\
\text { DOE Order } 420.1 \mathrm{~B}- \\
\end{array}$ & $\begin{array}{l}\text { - Can be designed to be compliant with } \\
\text { DOE-Order } 420.1 \mathrm{~B} \text {, } \\
\text { - Not a significant issue }\end{array}$ & $\begin{array}{l}\text { - Can be designed to be compliant with } \\
\text { DOE-Order } 420.1 \mathrm{~B} \text {. } \\
\text { - Not a significant issue }\end{array}$ & $\begin{array}{l}\text { - Can be designed to be compliant with } \\
\text { DOE-Order } 420.1 \mathrm{~B} \text {. } \\
\text { - Not a significant issue }\end{array}$ \\
\hline & $\begin{array}{l}4.6 .2 \\
\text { Minimize operational } \\
\text { impacts associated with } \\
\text { hazardous (generated) } \\
\text { waste handling }\end{array}$ & $\begin{array}{l}\text { - Suited for continuous operation. } \\
\text { - Secondary waste is routed to ETF } \\
\text { with no abnormal operational impact. }\end{array}$ & $\begin{array}{l}\text { - Suited for continuous operation. } \\
\text { - Cs product requiring volume } \\
\text { reduction is routed to evaporator with } \\
\text { no abnormal operational impact. } \\
\text { - Disposal of spent organics }\end{array}$ & $\begin{array}{l}\text { - Suited for continuous operation with } \\
\text { planned shutdown for resin change } \\
\text { outs. } \\
\text { - Used resin requires special handling } \\
\text { and disposal as LLW. This can be } \\
\text { designed in the facility to minimize } \\
\text { operational waste handling impacts. }\end{array}$ \\
\hline $\begin{array}{l}5 \text { PROGRAMMATIC } \\
\text { ASPECTS } \\
5.1 \text { Cost Impact }\end{array}$ & $\begin{array}{l}5.1 .1 \\
\text { Capital costs(for } \\
\text { comparative purposes } \\
\text { only) } \\
\end{array}$ & $\begin{array}{l}\text { - With expected accuracy range of - } \\
30 \% \text { to }+50 \% \text { : FC - CFF capital } \\
\text { costs }=\$ 64 \mathrm{M} \text { to } \$ 140 \mathrm{M}, \mathrm{FC}-\mathrm{RMF} \\
\text { capital costs }=\$ 75 \mathrm{M} \text { to } \$ 160 \mathrm{M} \text {. }\end{array}$ & $\begin{array}{l}\text { - With expected accuracy range of - } \\
30 \% \text { to }+50 \%: \text { CSSX - CFF capital } \\
\text { costs }=\$ 82 \mathrm{M} \text { to } \$ 180 \mathrm{M} \text {, CSSX- RMF } \\
\text { capital costs }=\$ 87 \mathrm{M} \text { to } \$ 190 \mathrm{M} \text {. }\end{array}$ & $\begin{array}{l}\text { - With expected accuracy range of - } \\
30 \% \text { to }+50 \% \text { : IX - CFF capital } \\
\text { costs }=\$ 54 \mathrm{M} \text { to } \$ 120 \mathrm{M}, \mathrm{IX}-\mathrm{RMF} \\
\text { capital costs }=\$ 59 \mathrm{M} \text { to } \$ 130 \mathrm{M} \text {. }\end{array}$ \\
\hline
\end{tabular}


RPP-RPT-38057, Rev. 0

Table B-1 - Cesium Separation Technology Assessment Summary Matrix

\begin{tabular}{|c|c|c|c|c|}
\hline Criteria & $\begin{array}{c}\text { Measures and } \\
\text { Definitions }\end{array}$ & Fractional Crystallization (FC) & $\begin{array}{l}\text { Caustic-Side Solvent Extraction } \\
\text { (CSSX) }\end{array}$ & Ion Exchange with sRF (IX-sRF) \\
\hline & $\begin{array}{l}5.1 .2 \\
\text { Project life cycle costs } \\
\text { for W-551 (for } \\
\text { comparative purposes } \\
\text { only) }\end{array}$ & $\begin{array}{l}\text { - With expected accuracy range of - } \\
30 \% \text { to }+50 \% \text { (applied to capital cost } \\
\text { contribution): FC - CFF life cycle } \\
\text { costs (w/o T\&Rs) }=\$ 180 \mathrm{M} \text { to } \\
\$ 250 \mathrm{M}, \mathrm{FC}-\mathrm{RMF} \text { life cycle costs } \\
\text { (w/o T\&Rs) } \$ 210 \mathrm{M} \text { to } \$ 290 \mathrm{M} \text {. } \\
\text { - } 2 \text { SST retrievals add } \$ 50 \mathrm{M} \text { of non- } \\
\text { project cost in } 4^{\text {th }} \text { year of mission } \\
\text { (FY-08); these are accelerated (not } \\
\text { new) costs }\end{array}$ & $\begin{array}{l}\text { - With expected accuracy range of - } \\
30 \% \text { to }+50 \% \text { (applied to capital cost } \\
\text { contribution): CSSX - CFF life cycle } \\
\text { costs (w/ evap) = } \$ 190 \mathrm{M} \text { to } \$ 290 \mathrm{M} \text {, } \\
\text { CSSX - RMF life cycle costs (w/ } \\
\text { evap) }=\$ 210 \mathrm{M} \text { to } \$ 310 \mathrm{M} \text {. }\end{array}$ & $\begin{array}{l}\text { - With expected accuracy range of - } \\
30 \% \text { to }+50 \% \text { (applied to capital cost } \\
\text { contribution): IX - CFF life cycle } \\
\text { costs }=\$ 140 \mathrm{M} \text { to } \$ 200 \mathrm{M} \text {, IX - RMF } \\
\text { life cycle costs }=\$ 150 \mathrm{M} \text { to } \$ 220 \mathrm{M} \text {. }\end{array}$ \\
\hline & $\begin{array}{l}5.1 .3 \\
\text { Cost profile (for } \\
\text { comparative purposes } \\
\text { only) }\end{array}$ & $\begin{array}{l}\text { - Both the highest capital cost and } \\
\text { highest life cycle (comparative) cost } \\
\text { result from pairing } \mathrm{FC} \text { with } \mathrm{RMF} \text {. }\end{array}$ & $\begin{array}{l}\text { - Lowest project capital (comparative) } \\
\text { cost is offered by pairing CSSX with } \\
\text { CFF. }\end{array}$ & $\begin{array}{l}\text { - Lowest life cycle (comparative) cost } \\
\text { is offered by pairing IX-sRF with } \\
\text { CFF. }\end{array}$ \\
\hline \multirow[t]{4}{*}{5.2 Schedule Impact } & $\begin{array}{l}5.2 .1 \\
\text { Implementation } \\
\text { schedule (confidence) - } \\
\text { for comparative } \\
\text { purposes only } \\
\end{array}$ & $\begin{array}{l}\text { - At } 50 \% \text { of probability of on-time } \\
\text { completion the estimated schedule } \\
\text { duration is } \mathbf{1 0 0} \text { months ( } 8.5 \text { years), } \\
\text { from CD-1 to Startup completion. }\end{array}$ & $\begin{array}{l}\text { - At } 50 \% \text { of probability of on-time } \\
\text { completion the estimated schedule } \\
\text { duration is } \mathbf{1 1 0} \text { months ( } 9 \text { years), from } \\
\text { CD-1 to Startup completion. }\end{array}$ & $\begin{array}{l}\text { - At } 50 \% \text { of probability of on-time } \\
\text { completion the estimated schedule } \\
\text { duration is } 90 \text { months ( } 7.5 \text { years), } \\
\text { from CD-1 to Startup completion. }\end{array}$ \\
\hline & $\begin{array}{l}5.2 .2 \\
\text { Licensing }\end{array}$ & $\begin{array}{l}\text { - Due to existing knowledge and } \\
\text { experience licensing activities should } \\
\text { not adversely impact. }\end{array}$ & $\begin{array}{l}\text { Due to lack of Hanford specific } \\
\text { performance knowledge, CSSX will } \\
\text { require additional efforts and time to } \\
\text { support licensing activities. }\end{array}$ & $\begin{array}{l}\text { - Due to existing knowledge and } \\
\text { experience licensing activities } \\
\text { should not be adversely impact. }\end{array}$ \\
\hline & \begin{tabular}{|l|}
5.2 .3 \\
Permitting
\end{tabular} & $\begin{array}{l}\text { - Assuming timely completion of } \\
\text { TC\&WM EIS and } 32 \text { months } \\
\text { permitting process per Tri-Party } \\
\text { Agreement, RCRA part B permitting } \\
\text { for FC will not impact start of } \\
\text { Construction. } \\
\end{array}$ & $\begin{array}{l}\text { - Assuming timely completion of } \\
\text { TC\&WM EIS and } 32 \text { months } \\
\text { permitting process per Tri-Party } \\
\text { Agreement, RCRA part B permitting } \\
\text { for CSSX will not impact start of } \\
\text { Construction. }\end{array}$ & $\begin{array}{l}\text { - Assuming timely completion of } \\
\text { TC\&WM EIS and } 32 \text { months } \\
\text { permitting process per Tri-Party } \\
\text { Agreement, RCRA part B permitting } \\
\text { for IX-sRF will not impact start of } \\
\text { Construction. } \\
\end{array}$ \\
\hline & $\begin{array}{l}5.2 .4 \\
D \& D\end{array}$ & $\begin{array}{l}\text { - Considerations for D\&D will be } \\
\text { accommodated during the IPS } \\
\text { design. Negligible impact on IPS } \\
\text { schedule. }\end{array}$ & $\begin{array}{l}\text { - Considerations for D\&D will be } \\
\text { accommodated during the IPS design. } \\
\text { Negligible impact on IPS schedule. }\end{array}$ & $\begin{array}{l}\text { - Considerations for D\&D will be } \\
\text { accommodated during the IPS } \\
\text { design. Negligible impact on IPS } \\
\text { schedule. }\end{array}$ \\
\hline
\end{tabular}


RPP-RPT-38057, Rev. 0

Table B-1 - Cesium Separation Technology Assessment Summary Matrix

\begin{tabular}{|c|c|c|c|c|}
\hline Criteria & $\begin{array}{l}\text { Measures and } \\
\text { Definitions }\end{array}$ & Fractional Crystallization (FC) & $\begin{array}{l}\text { Caustic-Side Solvent Extraction } \\
\text { (CSSX) }\end{array}$ & Ion Exchange with sRF (IX-sRF) \\
\hline \multirow[t]{2}{*}{5.3 DST Space } & $\begin{array}{l}5.3 .1 \\
\text { How fast DST space is } \\
\text { made available }\end{array}$ & $\begin{array}{l}\text { - Recovers DST space at a rate of } 1.1- \\
1.8 \mathrm{M} \text { gal/yr for the } 13 \text { batches from } \\
\text { retrieved from DSTs over } 4 \text { years } \\
\text { (assumes } 70 \% \text { TOE). } \\
\text { - Rate of DST space recovery depends } \\
\text { on the extent to which the phosphate } \\
\text { concentration needs to be kept below } \\
\text { 0.1 M } \\
\text { - Waste is retrieved from SSTs in } 5^{\text {th }} \\
\text { year, so that DST space is consumed. }\end{array}$ & $\begin{array}{l}\text { - Recovers DST space at a rate of } 600 \mathrm{~K} \\
\text { gal/yr (assumes } 70 \% \text { TOE over } 5 \text {-year } \\
\text { IPS mission, plus one additional year } \\
\text { to complete evaporation). }\end{array}$ & $\begin{array}{l}\text { - Recovers DST space at a rate of } \\
725 \mathrm{~K} \text { gal/yr (assumes } 70 \% \text { TOE). }\end{array}$ \\
\hline & $\begin{array}{l}5.3 .2 \\
\text { Amount of DST space }\end{array}$ & $\begin{array}{l}\text { Recovers between } 2.8 \text { and } 6.4 \mathrm{M} \\
\text { gallons of DST space, depending on } \\
\text { the extent to which the phosphate } \\
\text { concentration needs to be kept below } \\
0.1 \mathrm{M}\end{array}$ & $\begin{array}{l}\text { - Recovers } 3.7 \mathrm{M} \text { gallons of DST space. } \\
\text { (including evaporation) }\end{array}$ & $\begin{array}{l}\text { - Recovers } 3.7 \mathrm{M} \text { gallons of DST } \\
\text { space, but no additional evaporation } \\
\text { is required. }\end{array}$ \\
\hline \multirow[t]{2}{*}{$\begin{array}{l}5.4 \text { Impacts to WTP } \\
\text { and Supplemental } \\
\text { Treatment, positive } \\
\text { and negative }\end{array}$} & $\begin{array}{l}5.4 .1 \\
\text { Production rate impact }\end{array}$ & $\begin{array}{l}\text { - Will provide required feed rate of } \\
0.192 \mathrm{MT} \mathrm{Na} / \mathrm{hr} \text { to meet } \\
\text { WTP/supplemental treatment } \\
\text { production requirements. } \\
\text { - Sulfate concentration in FC feed may } \\
\text { adversely impact the production rate. } \\
\text { - Potentially will have to add Na to Cs- } \\
\text { loaded stream to maintain proper } \\
\text { feed solubility to WTP Pretreatment } \\
\text { (based upon WTP Al solubility } \\
\text { curves). }\end{array}$ & $\begin{array}{l}\text { - Will provide required feed rate of } \\
0.192 \mathrm{MT} \mathrm{Na} / \mathrm{hr} \text { to meet } \\
\text { WTP/supplemental treatment } \\
\text { production requirements. } \\
\text { - Impact of feed chemical composition } \\
\text { need to be made. } \\
\text { - Approximately } 1 / 3 \text { of } \mathrm{Na} \text { is cold } \\
\text { chemical addition to maintain } \mathrm{Al} \\
\text { solubility (based upon WTP Al } \\
\text { solubility curves) }\end{array}$ & $\begin{array}{l}\text { - Will provide required feed rate of } \\
0.192 \mathrm{MT} \mathrm{Na/hr} \text { to meet } \\
\text { WTP/supplemental treatment } \\
\text { production requirements. } \\
\text { - Impact of feed chemical composition } \\
\text { needs to be assessed } \\
\text { - Has a } \mathrm{NaOH} \text { load same as WTP ion } \\
\text { exchange system. } \\
\text { - Approximately } 1 / 3 \text { of } \mathrm{Na} \text { is cold } \\
\text { chemical addition to maintain } \mathrm{Al} \\
\text { solubility (based upon WTP Al } \\
\text { solubility curves) }\end{array}$ \\
\hline & $\begin{array}{l}5.4 .2 \\
\text { Mission duration }\end{array}$ & - No impact & - No impact & - No impact \\
\hline
\end{tabular}


RPP-RPT-38057, Rev. 0

Table B-1 - Cesium Separation Technology Assessment Summary Matrix

\begin{tabular}{|c|c|c|c|c|}
\hline Criteria & $\begin{array}{l}\text { Measures and } \\
\text { Definitions }\end{array}$ & Fractional Crystallization (FC) & $\begin{array}{c}\text { Caustic-Side Solvent Extraction } \\
\text { (CSSX) }\end{array}$ & Ion Exchange with sRF (IX-sRF) \\
\hline & $\begin{array}{l}5.4 .3 \\
\text { Number of high and low } \\
\text { level packages (need to } \\
\text { revise for 5-year } \\
\text { mission) }\end{array}$ & $\begin{array}{l}\text { - Produces 7,800 ILAW canisters } \\
\text { based on Na inventory of the LAW } \\
\text { feed. } \\
\text { - Number of canisters of ILAW would } \\
\text { increase if sulfate cannot be } \\
\text { sufficiently removed. } \\
\text { - Additional canisters of IHLW may } \\
\text { be produced in WTP depending on } \\
\text { the chemical composition of the Cs- } \\
\text { loaded waste stream. }\end{array}$ & $\begin{array}{l}\text { - Produces } 7,800 \text { ILAW canisters based } \\
\text { on Na inventory of the LAW feed. } \\
\text { - No additional HLW canisters are } \\
\text { produced. }\end{array}$ & $\begin{array}{l}\text { - Produces } 7,800 \text { ILAW canisters } \\
\text { based on Na inventory of the LAW } \\
\text { feed. } \\
\text { - No additional HLW canisters are } \\
\text { produced. }\end{array}$ \\
\hline & \begin{tabular}{|l}
5.4 .4 \\
Lessons Learned \\
benefits for WTP \\
pretreatment \\
\end{tabular} & $\begin{array}{l}\text { - There will not be "lessons learned" } \\
\text { from the operations and maintenance } \\
\text { of FC equipment in IPS. }\end{array}$ & $\begin{array}{l}\text {-There will not be "lessons learned" } \\
\text { from the operations and maintenance } \\
\text { of CSSX equipment in IPS. }\end{array}$ & $\begin{array}{l}\text { - Provides lessons learned benefits to } \\
\text { WTP ion exchange process } \\
\text { development, operation and } \\
\text { maintenance activities. }\end{array}$ \\
\hline & \begin{tabular}{|l}
5.4 .5 \\
Technology transfer to \\
WTP and/or \\
Supplemental Treatment
\end{tabular} & - Not applicable & - Not applicable & - Not applicable. \\
\hline & $\begin{array}{l}5.4 .6 \\
\text { ALARA } \\
\end{array}$ & $\begin{array}{l}\text { - No ALARA impact to WTP LAW } \\
\text { facility. }\end{array}$ & $\begin{array}{l}\text {-No ALARA impact to WTP LAW } \\
\text { facility. }\end{array}$ & $\begin{array}{l}\text { - No ALARA impact to WTP LAW } \\
\text { facility. } \\
\end{array}$ \\
\hline & \begin{tabular}{|l|}
5.4 .7 \\
Diversity of technology \\
\end{tabular} & $\begin{array}{l}\text { - Provides diversity of technology for } \\
\text { use at Hanford. }\end{array}$ & $\begin{array}{l}\text { Provides diversity of technology for } \\
\text { use at Hanford. }\end{array}$ & $\begin{array}{l}\text { - No new technology for use at } \\
\text { Hanford. } \\
\end{array}$ \\
\hline & $\begin{array}{l}5.4 .8 \\
\text { Positive programmatic } \\
\text { impacts and } \\
\text { opportunities }\end{array}$ & $\begin{array}{l}\text { - Provides alternative evaporator } \\
\text { capability } \\
\text { - Provides possibility of using grout } \\
\text { for immobilizing TC-free LAW }\end{array}$ & $\begin{array}{l}\text { - No programmatic benefits have been } \\
\text { identified yet. }\end{array}$ & $\begin{array}{l}\text { - Provides potential cost reduction } \\
\text { benefits by combining IPS and WTP } \\
\text { sRF technology deployment } \\
\text { activities. } \\
\text { - Potential use of IX for Tc removal } \\
\end{array}$ \\
\hline $\begin{array}{l}5.5 \text { Impacts to other } \\
\text { facilities e.g., ETF, } \\
\text { LAB, IDF (see } \\
\text { regulatory } \\
\text { assessment for IDF } \\
\text { impacts) }\end{array}$ & $\begin{array}{l}5.5 .1 \\
\text { Analytical equipment, } \\
\text { methods, and capacity }\end{array}$ & $\begin{array}{l}\text { - WTP LAW feed stream (cesium- } \\
\text { depleted product) will be analyzed at } \\
\text { WTP lab; Cesium-rich product } \\
\text { analyzed at } 222-S \text { lab; process } \\
\text { control analyses performed on-line at } \\
\text { IPS. } \\
\text { - Amount of lag storage for product } \\
\text { batches may require adjustment } \\
\text { based on laboratory analysis turn } \\
\text { around time. }\end{array}$ & $\begin{array}{l}\text {-WTP LAW feed stream (cesium- } \\
\text { depleted product) will be analyzed at } \\
\text { WTP lab; Cesium-rich product } \\
\text { analyzed at } 222-S \text { lab; process control } \\
\text { analyses performed on-line at IPS. } \\
\text { - Amount of lag storage for product } \\
\text { batches may require adjustment based } \\
\text { on laboratory analysis turn around } \\
\text { time. }\end{array}$ & $\begin{array}{l}\text { - WTP LAW feed stream (cesium- } \\
\text { depleted product) will be analyzed at } \\
\text { WTP lab; Cesium-rich product } \\
\text { analyzed at } 222-S \text { lab; process } \\
\text { control analyses performed on-line at } \\
\text { IPS. } \\
\text { - Amount of lag storage for product } \\
\text { batches may require adjustment } \\
\text { based on laboratory analysis turn } \\
\text { around time. }\end{array}$ \\
\hline
\end{tabular}


RPP-RPT-38057, Rev. 0

Table B-1 - Cesium Separation Technology Assessment Summary Matrix

\begin{tabular}{|c|c|c|c|c|}
\hline Criteria & $\begin{array}{l}\text { Measures and } \\
\text { Definitions }\end{array}$ & Fractional Crystallization (FC) & $\begin{array}{l}\text { Caustic-Side Solvent Extraction } \\
\text { (CSSX) }\end{array}$ & Ion Exchange with sRF (IX-sRF) \\
\hline & $\begin{array}{l}5.5 .2 \\
\text { Compliance to ETF } \\
\text { WAC - N/A }\end{array}$ & $\begin{array}{l}\text { - Process condensates from FC meet } \\
\text { ETF's WAC. }\end{array}$ & - No impact to ETF. & - No impact to ETF. \\
\hline & $\begin{array}{l}5.5 .3 \\
\text { ALARA }\end{array}$ & $\begin{array}{l}\text { - Because FC is being included as part } \\
\text { of the new IPS facility, ALARA will } \\
\text { be incorporated into its process } \\
\text { design. }\end{array}$ & $\begin{array}{l}\text { - Because CSSX is being included as } \\
\text { part of the new IPS facility, ALARA } \\
\text { will be incorporated into its process } \\
\text { design. }\end{array}$ & $\begin{array}{l}\text { - Because IX-sRF is being included as } \\
\text { part of the new IPS facility, ALARA } \\
\text { will be incorporated into its process } \\
\text { design. }\end{array}$ \\
\hline & $\begin{array}{l}5.5 .4 \\
\text { Number of Evaporator } \\
\text { campaigns }\end{array}$ & $\begin{array}{l}\text { - No evaporator campaigns required } \\
\text { because cesium-loaded stream meets } \\
\text { DST density and Na molarity } \\
\text { specifications. }\end{array}$ & $\begin{array}{l}\text {-Using the } 0.8 \mathrm{Ci} / \text { liter operating limit } \\
\text { for the } 242-\mathrm{A} \text { Evaporator, five }(5) \\
\text { evaporator campaigns will provide an } \\
\text { additional } 1.0 \mathrm{M} \text { gal of DST space. }\end{array}$ & $\begin{array}{l}\text { - No evaporator campaigns are } \\
\text { required because cesium-loaded } \\
\text { waste streams are near or exceed the } \\
0.8 \mathrm{Ci} / \text { liter operating limit for } 242-\mathrm{A} \\
\text { Evaporator. }\end{array}$ \\
\hline \multirow[t]{2}{*}{$\begin{array}{l}5.6 \text { Resources and } \\
\text { materials }\end{array}$} & $\begin{array}{l}5.6 .1 \\
\text { Availability of Key } \\
\text { Skills, Critical Materials, } \\
\text { Qualified Vendors }\end{array}$ & $\begin{array}{l}\text { - Does not use any specialty chemicals } \\
\text { or material. } \\
\text { - Uses engineered equipment to be } \\
\text { designed and fabricated by } \\
\text { experienced vendors. }\end{array}$ & $\begin{array}{l}\text { - Costner Industries Nevada Corp. is } \\
\text { the experienced commercial company } \\
\text { who is experienced with supplying } \\
\text { centrifugal contractors, due to their } \\
\text { working partnership with SRNL. } \\
\text { Other basic commercial suppliers do } \\
\text { exist. } \\
\text { - Solvents used are proprietary: such as } \\
\text { BOB CalixC6, TOA and Cs-7SB. } \\
\text { Suppliers are single source and may } \\
\text { have to pay premium price to obtain } \\
\text { these chemicals. - verify that these are } \\
\text { proprietary (check with Parsons) }\end{array}$ & $\begin{array}{l}\text { Two resin manufacturing facilities } \\
\text { have been identified and prepared } \\
\text { product tested. } \\
\text { - Long term supply strategy for resin } \\
\text { must be developed. }\end{array}$ \\
\hline & $\begin{array}{l}5.6 .2 \\
\text { Stability of Critical } \\
\text { Resource Pricing }\end{array}$ & $\begin{array}{l}\text { - Qualified fabricators may be difficult } \\
\text { to find }\end{array}$ & $\begin{array}{l}\text { Qualified fabricators may be difficult } \\
\text { to find }\end{array}$ & $\begin{array}{l}\text { - Qualified fabricators may be difficult } \\
\text { to find }\end{array}$ \\
\hline
\end{tabular}


RPP-RPT-38057, Rev. 0

\begin{tabular}{|c|c|c|c|c|c|c|c|c|}
\hline \multicolumn{9}{|c|}{$\begin{array}{c}\text { Table B-2 - Cesium Separation Technology Assessment Decision Calculator } \\
\text { (extracted from CH2M HILL 2008f) }\end{array}$} \\
\hline \multirow[t]{2}{*}{ \# } & \multirow[t]{2}{*}{ RPP-PLAN-37558 DECISION PLAN CRITERIA } & \multirow{2}{*}{$\begin{array}{c}\text { Weight } \\
(\%)\end{array}$} & \multicolumn{2}{|c|}{ FC } & \multicolumn{2}{|c|}{ CSSX } & \multicolumn{2}{|c|}{ IX } \\
\hline & & & $\begin{array}{c}\text { Raw } \\
\text { Ranking }\end{array}$ & $\begin{array}{l}\text { Weighted } \\
\text { Value }\end{array}$ & $\begin{array}{c}\text { Raw } \\
\text { Ranking }\end{array}$ & $\begin{array}{l}\text { Weighted } \\
\text { Value }\end{array}$ & $\begin{array}{c}\text { Raw } \\
\text { Ranking }\end{array}$ & $\begin{array}{l}\text { Weighted } \\
\text { Value }\end{array}$ \\
\hline 1.0 & Safety & 25.00 & & & & & & \\
\hline 1.1 & Process Safety & & & & & & & \\
\hline 1.1 .1 & $\begin{array}{l}\text { Quantity of material at risk (MAR) - radiological and } \\
\text { chemical - less is better }\end{array}$ & & 5 & 0.94 & 5 & 0.94 & 5 & 0.94 \\
\hline 1.1.2 & $\begin{array}{l}\text { Concentration of radiological and chemical MAR - less is } \\
\text { better }\end{array}$ & & 4 & 0.75 & 5 & 0.94 & 5 & 0.94 \\
\hline 1.1 .3 & $\begin{array}{l}\text { Dispersability of the MAR - less dispersible form is better } \\
\text { (e.g., solids over liquids over powders over gases) }\end{array}$ & & 5 & 0.94 & 5 & 0.94 & 3 & 0.56 \\
\hline 1.1 .4 & $\begin{array}{l}\text { Dispersive energy, e.g., heat, off gassing, pressure, etc. } \\
\text { inherent in the process - less dispersive energy is better }\end{array}$ & & 5 & 0.94 & 5 & 0.94 & 5 & 0.94 \\
\hline 1.1 .5 & $\begin{array}{l}\text { Process Stability - including ease of process } \\
\text { control/shutdown -- easier/faster process shutdown is better }\end{array}$ & & 6 & 1.13 & 5 & 0.94 & 4 & 0.75 \\
\hline 1.1 .6 & $\begin{array}{l}\text { Process that does not create a new or exacerbate an existing } \\
\text { Tank Farm hazard is preferred to one that does }\end{array}$ & & 5 & 0.94 & 5 & 0.94 & 5 & 0.94 \\
\hline 1.1 .7 & $\begin{array}{l}\text { Less fire hazard (e.g. less quantity of combustibles, } \\
\text { including flammable gas, less flammable combustibles, etc.) }\end{array}$ & & 6 & 1.13 & 2 & 0.38 & 4 & 0.75 \\
\hline 1.1.8 & $\begin{array}{l}\text { Reactive Chemicals - Process with less reactive chemicals } \\
\text { (reactivity) is better }\end{array}$ & & 6 & 1.13 & 4 & 0.75 & 4 & 0.75 \\
\hline 1.2 & Criticality Safety & & & & & & & \\
\hline 1.2 .1 & $\begin{array}{l}\text { A Process that is inherently sub critical is preferred over a } \\
\text { process that relies on criticality controls }\end{array}$ & & 5 & 1.25 & 5 & 1.25 & 5 & 1.25 \\
\hline 1.3 & Industrial Safety and Hygiene & & & & & & & \\
\hline 1.3.1 & Less hazards/less severe hazardous is better (e.g.,...) & & 5 & 3.75 & 4 & 3.00 & 4 & 3.00 \\
\hline & & & Subtotals & 13 & & 11 & & 11 \\
\hline 2.0 & Regulator and Stakeholder Acceptance & 20.00 & & & & & & \\
\hline 2.1 & Achieve Tribal Nations / stakeholders' acceptance & & & & & & & \\
\hline 2.1.1 & Early waste treatment enabled & & 5 & 2.00 & 4 & 1.60 & 7 & 2.80 \\
\hline 2.1 .2 & Land usage (more contaminated ground) & & 4 & 1.60 & 4 & 1.60 & 6 & 2.40 \\
\hline 2.2 & Achieve regulators' acceptance & & & & & & & \\
\hline 2.2 .1 & $\begin{array}{l}\text { Compliance with applicable regulations (RCRA, CAA, } \\
\text { NESHAPS, NEPA/SEPA, NPDES, DOE Orders) }\end{array}$ & & 5 & 1.50 & 5 & 1.50 & 5 & 1.50 \\
\hline 2.2 .2 & Impact to Disposal System Performance & & 10 & 3.00 & 5 & 1.50 & 5 & 1.50 \\
\hline
\end{tabular}


RPP-RPT-38057, Rev. 0

\begin{tabular}{|c|c|c|c|c|c|c|c|c|}
\hline \multicolumn{9}{|c|}{$\begin{array}{c}\text { Table B-2 - Cesium Separation Technology Assessment Decision Calculator } \\
\text { (extracted from CH2M HILL 2008f) }\end{array}$} \\
\hline \multirow[t]{2}{*}{ \# } & \multirow[t]{2}{*}{ RPP-PLAN-37558 DECISION PLAN CRITERIA } & \multirow{2}{*}{$\begin{array}{c}\text { Weight } \\
(\%)\end{array}$} & \multicolumn{2}{|c|}{ FC } & \multicolumn{2}{|c|}{ CSSX } & \multicolumn{2}{|c|}{ IX } \\
\hline & & & $\begin{array}{c}\text { Raw } \\
\text { Ranking }\end{array}$ & $\begin{array}{l}\text { Weighted } \\
\text { Value }\end{array}$ & $\begin{array}{c}\text { Raw } \\
\text { Ranking }\end{array}$ & $\begin{array}{l}\text { Weighted } \\
\text { Value }\end{array}$ & $\begin{array}{c}\text { Raw } \\
\text { Ranking }\end{array}$ & $\begin{array}{l}\text { Weighted } \\
\text { Value }\end{array}$ \\
\hline 2.2 .3 & Secondary Waste Form and Quantity & & 5 & 1.50 & 5 & 1.50 & 5 & 1.50 \\
\hline \multirow[t]{2}{*}{2.2 .4} & Potential impacts to other permitted facilities & & 5 & 1.50 & 5 & 1.50 & 5 & 1.50 \\
\hline & & & Subtotals & 11 & & 9 & & 11 \\
\hline \multirow{3}{*}{$\begin{array}{l}3.0 \\
3.1 \\
3.1 .1\end{array}$} & \multirow{3}{*}{$\begin{array}{l}\text { Technical Maturity/Flexibility } \\
\text { Technology Readiness Level } \\
\text { Technology Readines Level Number }\end{array}$} & 20.00 & & & & & & \\
\hline & & & & & & & & \\
\hline & & & 5 & 2.00 & 4 & 1.60 & 5 & 2.00 \\
\hline 3.1 .2 & Effort to mature technology & & 6 & 2.40 & 4 & 1.60 & 5 & 2.00 \\
\hline 3.1 .3 & Probability of success & & 5 & 2.00 & 4 & 1.60 & 5 & 2.00 \\
\hline \multirow{2}{*}{$\begin{array}{l}3.2 \\
3.2 .1\end{array}$} & \multirow{2}{*}{$\begin{array}{l}\text { Process Flexibility and robustness } \\
\text { Ability to process a variety of feeds }\end{array}$} & & & & & & & \\
\hline & & & 4 & 0.53 & 4 & 0.53 & 6 & 0.80 \\
\hline 3.2 .2 & Ability to adjust process rate & & 5 & 0.67 & 4 & 0.53 & 4 & 0.53 \\
\hline 3.2 .3 & Flexibility to modify product & & 3 & 0.40 & 2 & 0.27 & 2 & 0.27 \\
\hline \multirow{4}{*}{$\begin{array}{l}3.2 .4 \\
3.2 .5 \\
3.2 .6\end{array}$} & \multirow{4}{*}{$\begin{array}{l}\text { Ability to expand } \\
\text { Recover from out of spec product } \\
\text { Technology applicability to other DOE complex projects }\end{array}$} & & 2 & 0.27 & 1 & 0.13 & 2 & 0.27 \\
\hline & & & 5 & 0.67 & 5 & 0.67 & 5 & 0.67 \\
\hline & & & 2 & 0.27 & 3 & 0.40 & 3 & 0.40 \\
\hline & & & Subtotals & 9 & & 7 & & 9 \\
\hline 4.0 & Operability and Maintainability & 15.00 & & & & & & \\
\hline \multirow{2}{*}{$\begin{array}{l}4.1 \\
4.1 .1\end{array}$} & \multirow{2}{*}{$\begin{array}{l}\text { Ease of Process control and operation } \\
\text { Minimize number and frequency of surveillances }\end{array}$} & & & & & & & \\
\hline & & & 5 & 0.15 & 4 & 0.12 & 6 & 0.18 \\
\hline 4.1 .2 & Minimize number of people to operate & & 5 & 0.15 & 5 & 0.15 & 5 & 0.15 \\
\hline 4.1 .3 & Ease of startup and shutdown & & 5 & 0.15 & 4 & 0.12 & 7 & 0.21 \\
\hline \multirow{3}{*}{$\begin{array}{l}4.1 .4 \\
4.1 .5 \\
4.1 .6\end{array}$} & \multirow{3}{*}{$\begin{array}{l}\text { Minimize system complexity } \\
\text { Minimize number of chemicals needed } \\
\text { Minimize number of process and regulatory samples }\end{array}$} & & 5 & 0.15 & 3 & 0.09 & 7 & 0.21 \\
\hline & & & 7 & 0.21 & 3 & 0.09 & 5 & 0.15 \\
\hline & & & 6 & 0.18 & 3 & 0.09 & 5 & 0.15 \\
\hline 4.1.7 & Batch verses continuous & & 5 & 0.15 & 5 & 0.15 & 4 & 0.12 \\
\hline 4.1 .8 & Ease of entry and exit from standby & & 5 & 0.15 & 4 & 0.12 & 5 & 0.15 \\
\hline \multirow{2}{*}{$\begin{array}{r}4.1 .9 \\
4.1 .10\end{array}$} & \multirow{2}{*}{$\begin{array}{l}\text { Wide operating margin } \\
\text { Complexity of transfers to, from and within Tank Farms }\end{array}$} & & 5 & 0.15 & 3 & 0.09 & 6 & 0.18 \\
\hline & & & 5 & 0.15 & 5 & 0.15 & 5 & 0.15 \\
\hline 4.2 & ALARA & & & & & & & \\
\hline 4.2 .1 & $\begin{array}{l}\text { Less required contact maintenance is better, etc. (rad and } \\
\text { tox) }\end{array}$ & & 5 & 1.50 & 4 & 1.20 & 6 & 1.80 \\
\hline
\end{tabular}


RPP-RPT-38057, Rev. 0

\begin{tabular}{|c|c|c|c|c|c|c|c|c|}
\hline \multicolumn{9}{|c|}{$\begin{array}{c}\text { Table B-2 - Cesium Separation Technology Assessment Decision Calculator } \\
\text { (extracted from CH2M HILL 2008f) }\end{array}$} \\
\hline \multirow[t]{2}{*}{ \# } & \multirow[t]{2}{*}{ RPP-PLAN-37558 DECISION PLAN CRITERIA } & \multirow{2}{*}{$\begin{array}{c}\text { Weight } \\
(\%)\end{array}$} & \multicolumn{2}{|c|}{ FC } & \multicolumn{2}{|c|}{ CSSX } & \multicolumn{2}{|c|}{ IX } \\
\hline & & & $\begin{array}{l}\text { Raw } \\
\text { Ranking }\end{array}$ & $\begin{array}{l}\text { Weighted } \\
\text { Value }\end{array}$ & $\begin{array}{c}\text { Raw } \\
\text { Ranking }\end{array}$ & $\begin{array}{l}\text { Weighted } \\
\text { Value }\end{array}$ & $\begin{array}{c}\text { Raw } \\
\text { Ranking }\end{array}$ & $\begin{array}{l}\text { Weighted } \\
\text { Value }\end{array}$ \\
\hline 4.3 & Reliability & & & & & & & \\
\hline 4.3 .1 & Number of active components & & 5 & 0.68 & 3 & 0.41 & 6 & 0.81 \\
\hline 4.3 .2 & Reliability of analogous systems & & 5 & 0.68 & 5 & 0.68 & 5 & 0.68 \\
\hline 4.4 & Ease and frequency of maintenance & & & & & & & \\
\hline 4.4.1 & Minimize number of support systems & & 4 & 0.30 & 5 & 0.38 & 5 & 0.38 \\
\hline 4.4 .2 & Minimize number and frequency of PM's & & 5 & 0.38 & 4 & 0.30 & 6 & 0.45 \\
\hline 4.4 .3 & Minimize maintenance in zone entries & & 5 & 0.38 & 4 & 0.30 & 6 & 0.45 \\
\hline 4.4 .4 & Minimize specialized equipment and parts & & 5 & 0.38 & 3 & 0.23 & 5 & 0.38 \\
\hline 4.4 .5 & Minimize tank entries & & 0 & & 0 & & 0 & \\
\hline 4.5 & Ease of Implementation & & & & & & & \\
\hline 4.5 .1 & Ease of training & & 5 & 0.30 & 4 & 0.24 & 6 & 0.36 \\
\hline 4.5 .2 & Complexity of procedures & & 5 & 0.30 & 4 & 0.24 & 6 & 0.36 \\
\hline 4.5 .3 & Similar to other process facilities on site & & 5 & 0.30 & 3 & 0.18 & 5 & 0.30 \\
\hline 4.6 & Liquid/solid secondary waste & & & & & & & \\
\hline 4.6.1 & $\begin{array}{l}\text { Waste handling compatible with existing systems as defined } \\
\text { by DOE Order } 420.1 \mathrm{~B}\end{array}$ & & 0 & & 0 & & 0 & \\
\hline 4.6 .2 & $\begin{array}{l}\text { Minimize operational impacts associated with hazardous } \\
\text { (generated) waste handling }\end{array}$ & & 6 & 0.90 & 4 & 0.60 & 4 & 0.60 \\
\hline & & & Subtotals & 8 & & 6 & & 8 \\
\hline 5.0 & Programmatic Aspects & 20.00 & & & & & & \\
\hline 5.1 & Cost Impacts & & & & & & & \\
\hline 5.1 .1 & Capital costs & & 5 & 0.83 & 3 & 0.50 & 7 & 1.17 \\
\hline 5.1 .2 & Life cycle costs & & 4 & 0.67 & 4 & 0.67 & 7 & 1.17 \\
\hline 5.1 .3 & Cost profile & & 5 & 0.83 & 4 & 0.67 & 6 & 1.00 \\
\hline 5.2 & Schedule Impact & & & & & & & \\
\hline 5.2 .1 & Overall schedule (confidence) & & 5 & 0.63 & 4 & 0.50 & 6 & 0.75 \\
\hline 5.2 .2 & Licensing & & 5 & 0.63 & 3 & 0.38 & 5 & 0.63 \\
\hline 5.2 .3 & Permitting & & 5 & 0.63 & 5 & 0.63 & 5 & 0.63 \\
\hline 5.2 .4 & D\&D & & 5 & 0.63 & 5 & 0.63 & 5 & 0.63 \\
\hline 5.3 & DST Space & & & & & & & \\
\hline 5.3 .1 & How fast DST space is made available & & 8 & 2.00 & 4 & 1.00 & 5 & 1.25 \\
\hline
\end{tabular}


RPP-RPT-38057, Rev. 0

\begin{tabular}{|c|c|c|c|c|c|c|c|c|}
\hline \multicolumn{9}{|c|}{$\begin{array}{c}\text { Table B-2 - Cesium Separation Technology Assessment Decision Calculator } \\
\text { (extracted from CH2M HILL 2008f) }\end{array}$} \\
\hline \multirow[t]{2}{*}{ \# } & \multirow{2}{*}{ RPP-PLAN-37558 DECISION PLAN CRITERIA } & \multirow{2}{*}{$\begin{array}{c}\text { Weight } \\
(\%)\end{array}$} & \multicolumn{2}{|c|}{ FC } & \multicolumn{2}{|c|}{ CSSX } & \multicolumn{2}{|c|}{ IX } \\
\hline & & & $\begin{array}{c}\text { Raw } \\
\text { Ranking }\end{array}$ & $\begin{array}{l}\text { Weighted } \\
\text { Value }\end{array}$ & $\begin{array}{c}\text { Raw } \\
\text { Ranking }\end{array}$ & $\begin{array}{l}\text { Weighted } \\
\text { Value }\end{array}$ & $\begin{array}{c}\text { Raw } \\
\text { Ranking }\end{array}$ & $\begin{array}{l}\text { Weighted } \\
\text { Value }\end{array}$ \\
\hline 5.3 .2 & Amount of DST space & & 6 & 1.50 & 4 & 1.00 & 5 & 1.25 \\
\hline 5.4 & $\begin{array}{l}\text { Impacts to WTP and Supplemental Treatment, positive } \\
\text { and negative }\end{array}$ & & & & & & & \\
\hline 5.4 .1 & Production rate impact & & 5 & 0.21 & 5 & 0.21 & 5 & 0.21 \\
\hline 5.4 .2 & Mission duration & & 5 & 0.21 & 5 & 0.21 & 5 & 0.21 \\
\hline 5.4 .3 & Number of high and low level packages & & 5 & 0.21 & 5 & 0.21 & 5 & 0.21 \\
\hline 5.4 .4 & Lessons Learned benefits for WTP pretreatment & & 2 & 0.09 & 2 & 0.09 & 8 & 0.34 \\
\hline 5.4 .5 & Technology transfer to WTP & & 0 & & 0 & & 0 & \\
\hline 5.4 .6 & ALARA & & 3 & 0.13 & 1 & 0.04 & 1 & 0.04 \\
\hline 5.4 .7 & Diversity of technology & & 3 & 0.13 & 2 & 0.09 & 1 & 0.04 \\
\hline 5.4 .8 & Positive programmatic impacts and opportunities & & 6 & 0.26 & 2 & 0.09 & 4 & 0.17 \\
\hline 5.5 & Impacts to other facilities e.g., ETF, LAB & & & & & & & \\
\hline 5.5 .1 & Analytical equipment, methods, and capacity & & 5 & 0.17 & 5 & 0.17 & 5 & 0.17 \\
\hline 5.5 .2 & Compliance to ETF WAC & & 5 & 0.17 & 5 & 0.17 & 5 & 0.17 \\
\hline 5.5 .3 & ALARA & & 5 & 0.17 & 5 & 0.17 & 5 & 0.17 \\
\hline 5.5 .4 & Number of Evaporator campaigns & & 0 & & 0 & & 0 & \\
\hline 5.6 & Resources and materials & & & & & & & \\
\hline 5.6 .1 & $\begin{array}{l}\text { Availability of Key Skills, Critical Materials, Qualified } \\
\text { Vendors }\end{array}$ & & 6 & 0.30 & 4 & 0.20 & 4 & 0.20 \\
\hline 5.6 .2 & Stability of Critical Resource Pricing & & 5 & 0.25 & 5 & 0.25 & 5 & 0.25 \\
\hline & & & Subtotals & 11 & & 8 & & 11 \\
\hline & TOTALS & & 334 & $\overline{51}$ & 268 & 41 & 333 & $\overline{50}$ \\
\hline
\end{tabular}


RPP-RPT-38057, Rev. 0

\section{ATTACHMENT C. COST PROFILES AND SUMMARY SCHEDULES}

\section{C.1. COST ESTIMATES}

Cost estimates were prepared for each of the six possible combinations of entrained solids filtration and cesium separations technologies, namely for $\mathrm{FC} / \mathrm{CFF}, \mathrm{FC} / \mathrm{RMF}, \mathrm{CSSX} / \mathrm{CFF}$, CSSX/RMF, IX-sRF/CFF, and IX-sRF/RMF. As required by the Decision Plan, three types of cost estimates were prepared, capital cost for design and construction, and life-cycle costs for the 5-year IPS mission duration (including capital costs and a sixth year for decommissioning), and a year-by-year cost profile for the IPS life-cycle.

When paired with any of the 3 Cs separation technologies, cross-flow filtration (CFF) was consistently estimated to have a lower capital and life-cycle cost than the rotary micro-filtration system. This difference was primarily attributed to the installation and operation of the RMF in a potentially contaminated work zone, i.e. in a DST riser and its associated pump pit, for the IXsRF and CSSX processing options and the higher cost of the RMF units. Because of its significantly larger throughput, the FC processing option required a larger number of RMF units that could not be accommodated in the available DST riser, so they were relocated to the IPS facility. However, this relocation also required a facility footprint that was larger than that required for the CFF units.

Both capital and life-cycle cost estimates for the IX-sRF process were lower than either the CSSX or FC processes, regardless of which filtration process it was paired with. While the estimated capital cost of FC was lower than that for CSSX, regardless of the selected filtration process, the total life-cycle costs for both FC and CSSX were estimated to be approximately the same.

A limited review of the cost drivers was performed using the CFF pairs to determine what the major drivers were for the differences in capital and life cycle costs. IX-sRF costs were used as the basis for comparison, as it was consistently the lowest cost option in all categories.

The major differences in cost between $\mathrm{FC} / \mathrm{CFF}$ and IX-sRF/CFF were in the following areas.

- First, the technology specific equipment required for $\mathrm{FC} / \mathrm{CFF}$ is significantly larger than for IX-sRF/CFF resulting in equipment costs that were 2.7 times more expensive. The major FC/CFF cost items were the Reboiler, Crystallizer, and Chilled Water System. Furthermore, because the flow rates required by FC are about 3 times that for IX-sRF, the size and cost of the CFF to support the process is greater by a factor of 3 as well. The capital construction and startup costs were approximately $20 \%$ greater for $\mathrm{FC}$, primarily again due to the facility footprint and equipment size.

- Secondly, consumables required to support FC Operations is more than double that for IX-sRF, driven mainly by the fuel costs to generate steam. This, plus the above account for approximately $\$ 30 \mathrm{M}$ of the cost difference 
- Finally the last major cost difference is in the incremental implementation costs required to provide the additional feed required by $\mathrm{FC}$ over the 5 year mission, as discussed in Section 0 . This additional feed requires an incremental 16 tank to tank transfers, 2 SST retrievals and 3 cross-site transfers above and beyond the tank to tank transfers required for either IX-sRF or CSSX, increasing the life cycle costs for FC by an estimated $\$ 50-$ $60 \mathrm{M}$ during the mission period.

The major differences in cost between CSSX/CFF and IX-sRF/CFF are:

- The cost for the technology specific equipment required for CSSX/CFF is about 5.7 times that for IX-sRF and driven by the cost of the 43 centrifugal contactors (the centrifugal contactors are about $80 \%$ of the technology specific equipment procurement costs). Overall the capital construction and startup costs were over $50 \%$ greater for CSSX compared to IX-sRF, primarily due to the facility footprint, equipment costs and more complex process startup.

- The above increase in capital costs also translates to a comparable increase in the D\&D costs for the CSSX facility.

- Finally, the last major cost difference is in the incremental implementation costs are those for 242-Evaporator operation in order to recover as much DST space as possible, as discussed in Section 3.2.5. The cost for the 242-Evaporator operation in support of CSSX over the mission period is estimated at just over $\$ 10 \mathrm{M}$.

Since the cost profiles for construction were developed without optimizing or level loading, no conclusion regarding cost outlay with time can be reliably assessed at this time. The operating costs are essentially the same as all technologies would require equivalent crew size to operate. The exception to that is spike in the fourth year of IPS operation due to the anticipated need to change out the RMF units. However, it should be noted that no attempt has been made to optimize the cost profiles, i.e. to minimize cost spikes such as those that typically occurred in the last year of construction.

Capital and life-cycle costs for each of the six combinations of entrained solids filtration and Cs separation technologies are summarized in Figure C-1 and Figure C-2. Cost profiles for each of the technology combinations are shown in Figure C-3 through Figure C-8. It should be noted that these are Class 4 estimate per the Association for the Advancement of Cost Engineering (AACE) International definitions. A Class 4 estimate has an expected accuracy range from a minus $30 \%$ to a plus $50 \%$. Furthermore the cost estimates do not reflect a total project as they do not contain costs for common systems required by all technologies (e.g., control systems, fire protection systems, etc) and were used only for the purpose of comparing the respective technology pairs. 
Figure C-1 - Capital Cost Estimate Summary

(For Technology comparison purposes only)

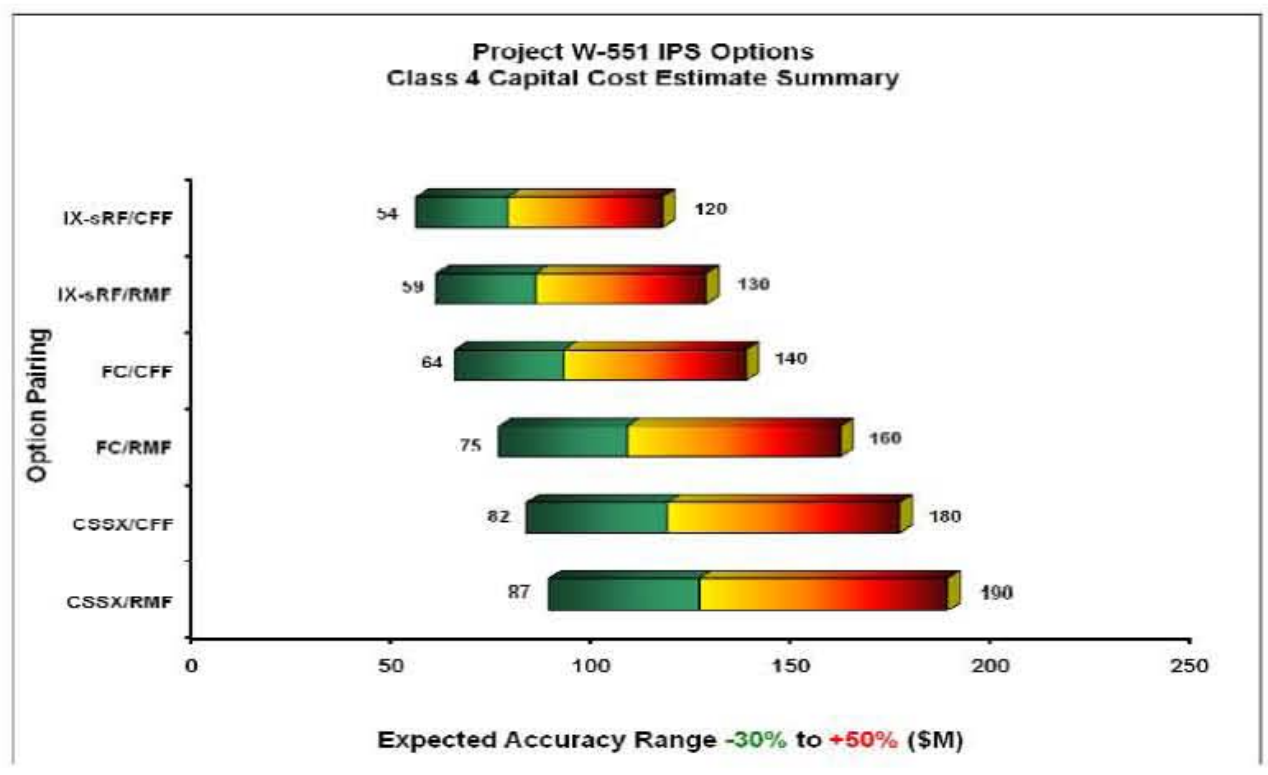

Figure C-2 - Life Cycle Cost Estimate Summary

(For Technology comparison purposes only)

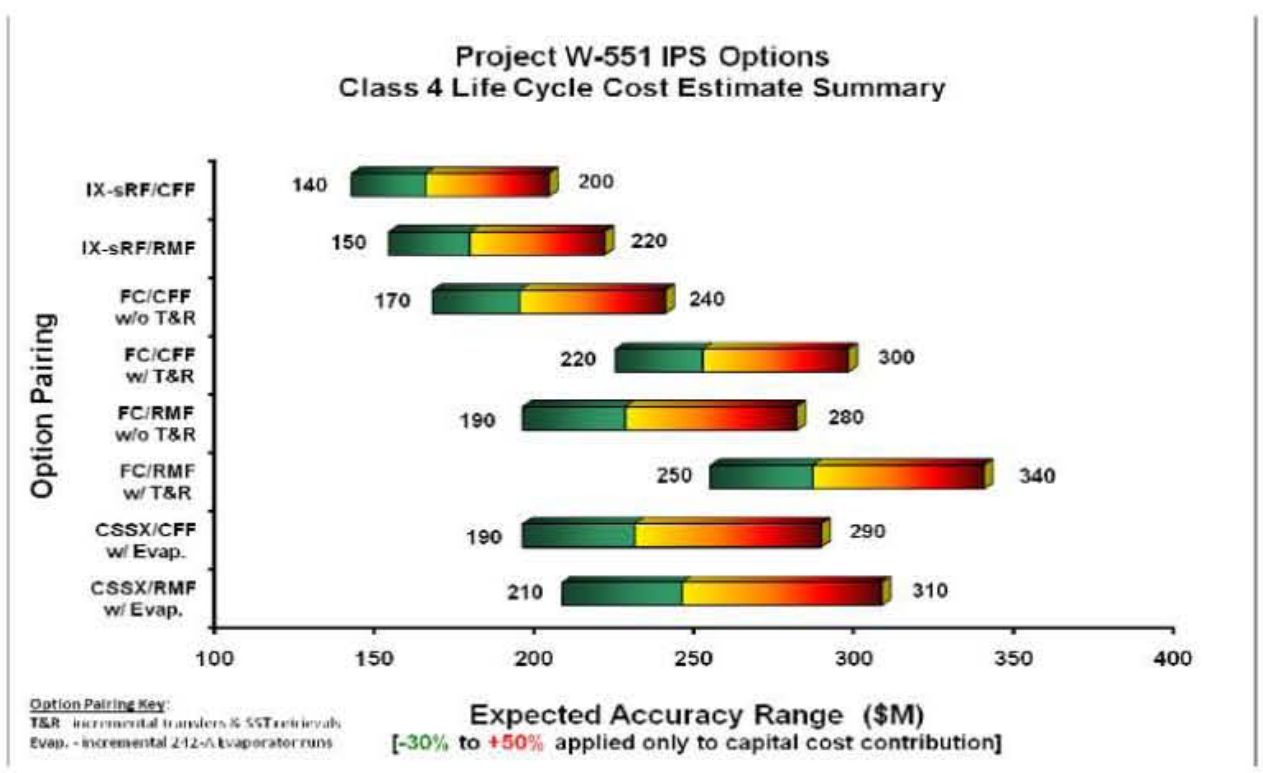

ICosts estimates are for comparative purposes between the technologies only \& DO NOT reflect the total IPS project cost] 


\section{Figure C-3 - Cost Profile for IX-SRF/CFF Technology Pair}

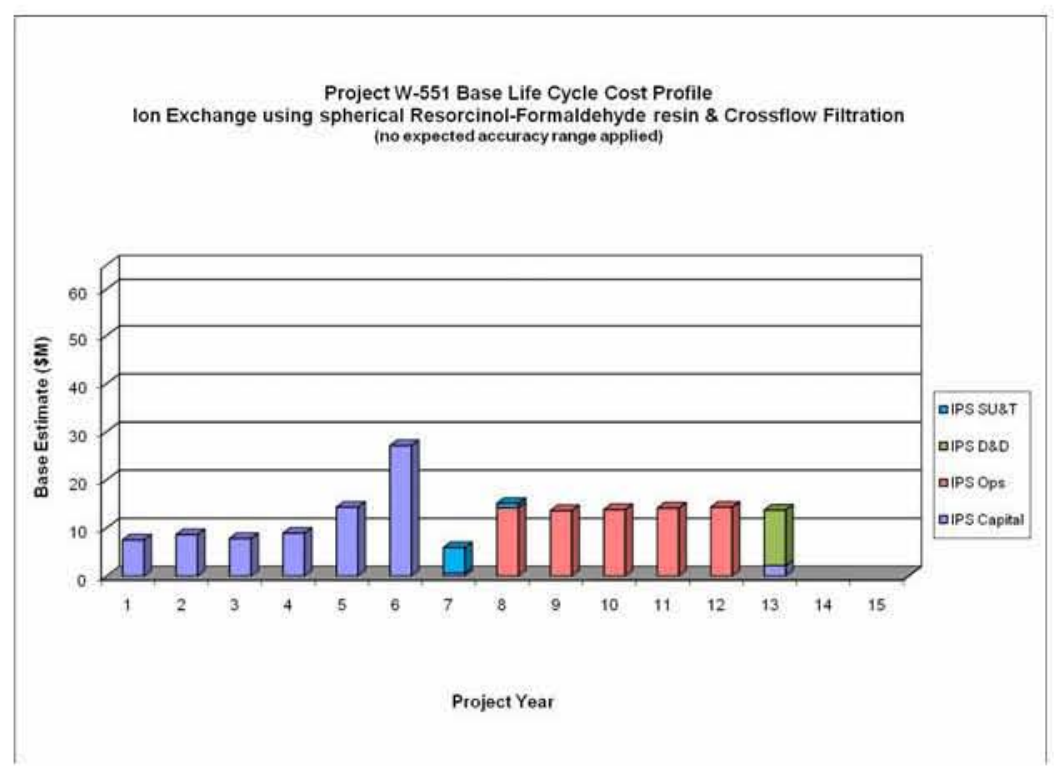

Figure C-4 - Cost Profile for IX-SRF/RMF Technology Pair

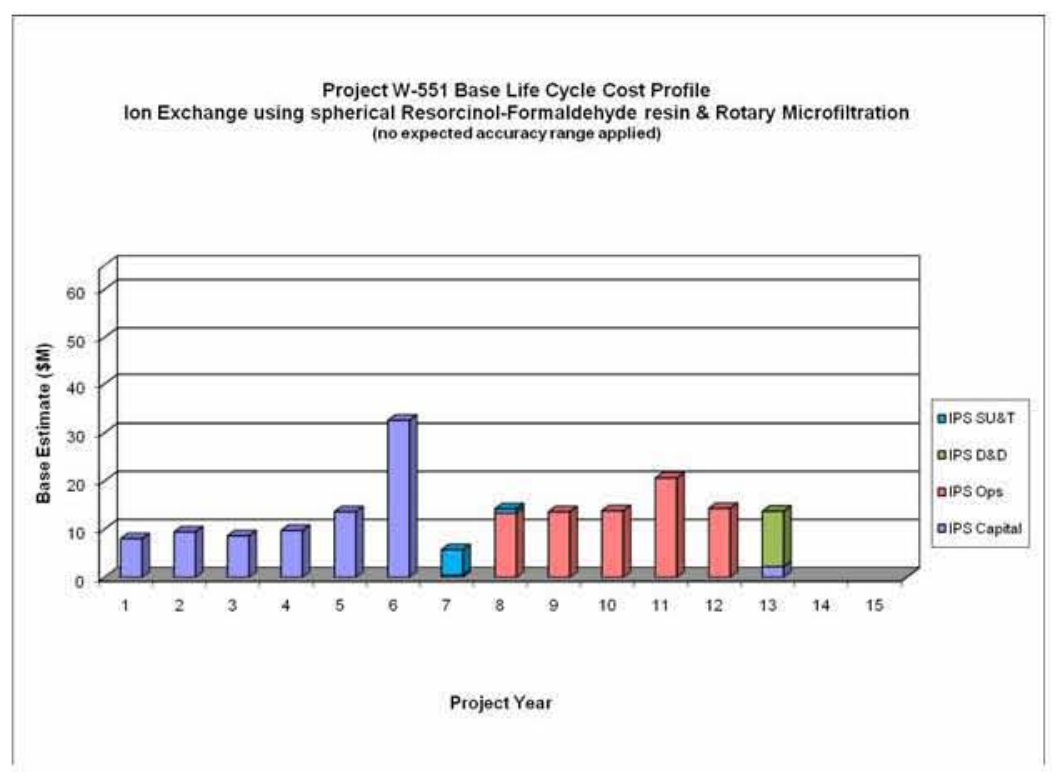

SU\&T - Start Up \& Testing

D\&D - Decontamination \& Decommissioning

ICosts estimates are for comparative purposes between the technologies only \& DO NOT reflect the total IPS project cost] 
Figure C-5 - Cost Profile for FC/CFF Technology Pair

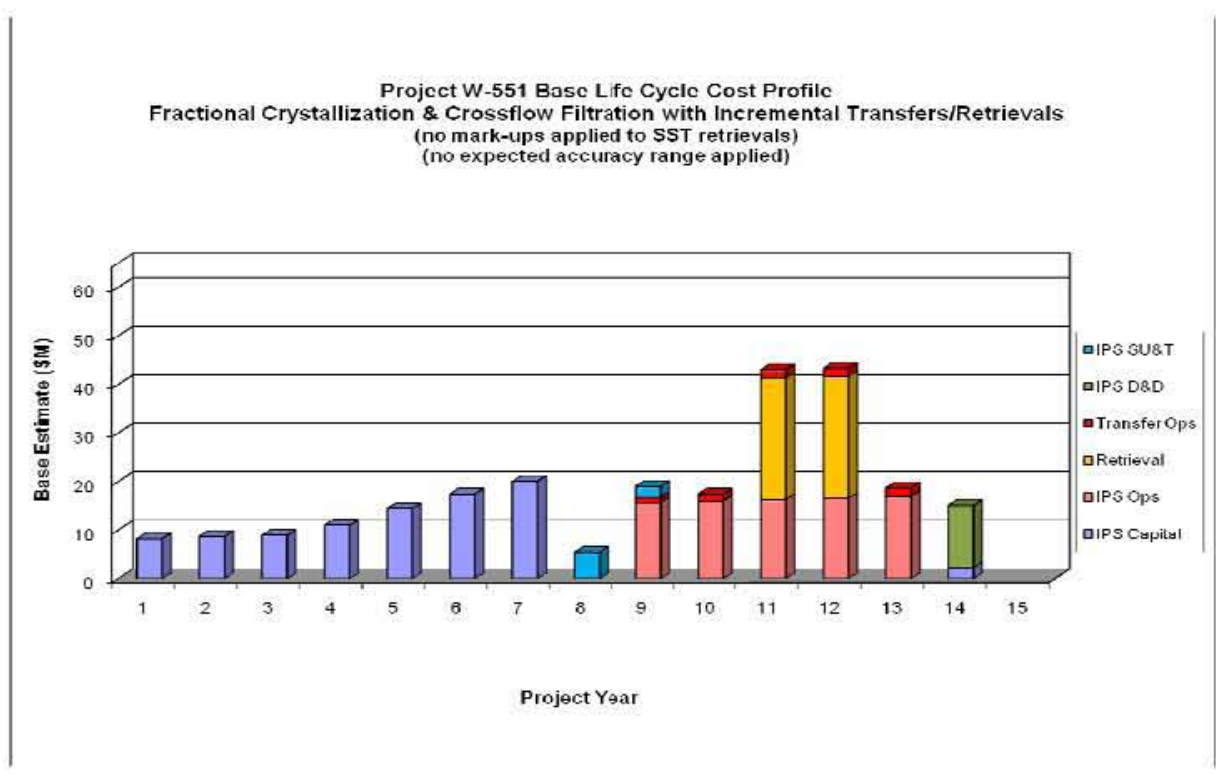

Figure C-6 - Cost Profile for FC/RMF Technology Pair

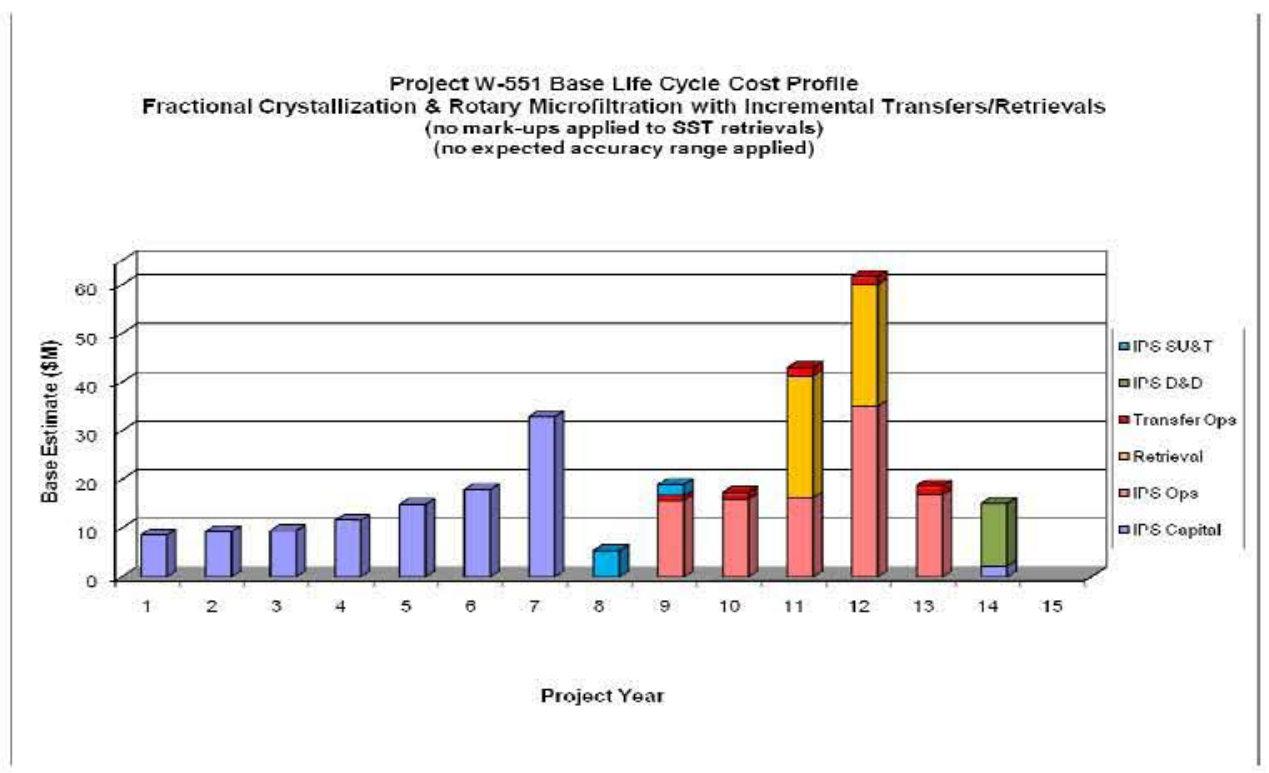

SU\&T - Start Up \& Testing

D\&D - Decontamination \& Decommissioning

ICosts estimates are for comparative purposes between the technologies only \& DO NOT reflect the total IPS project cost] 
Figure C-7 - Cost Profile for CSSX/CFF Technology Pair

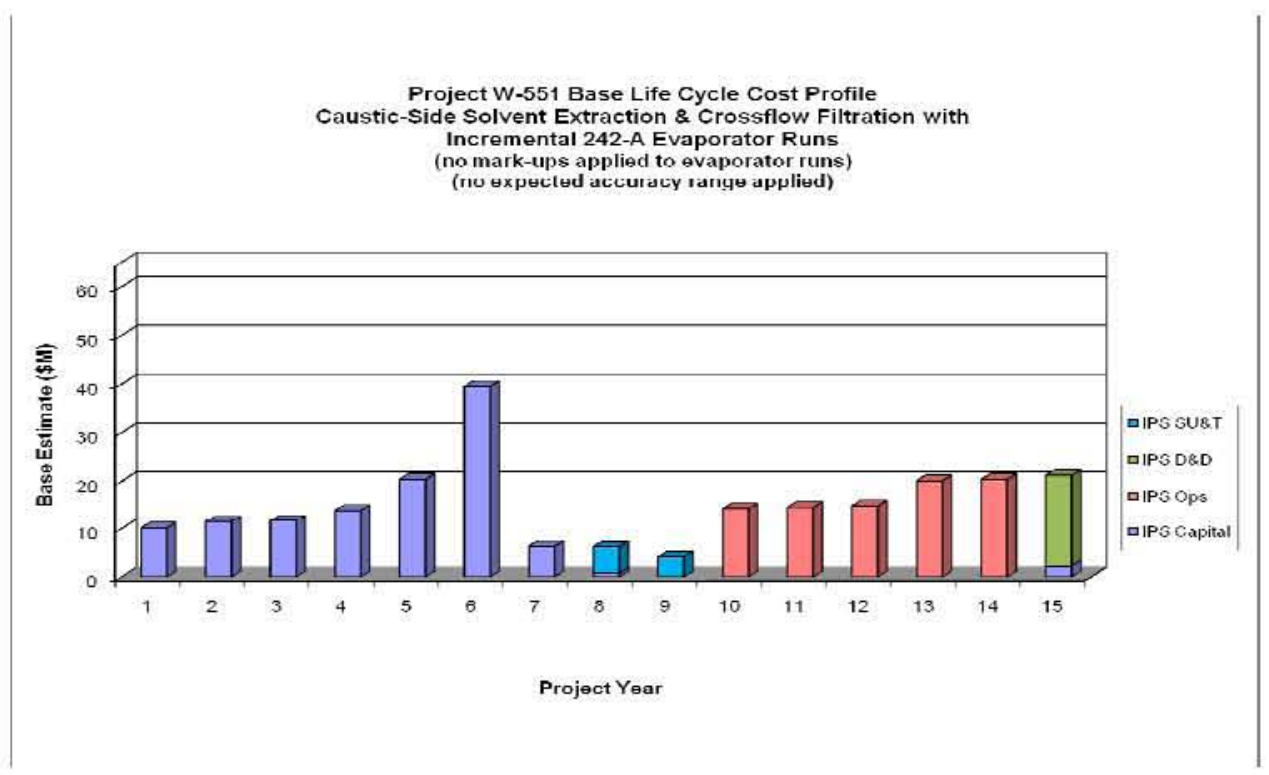

Figure C-8 - Cost Profile for CSSX/RMF Technology Pair

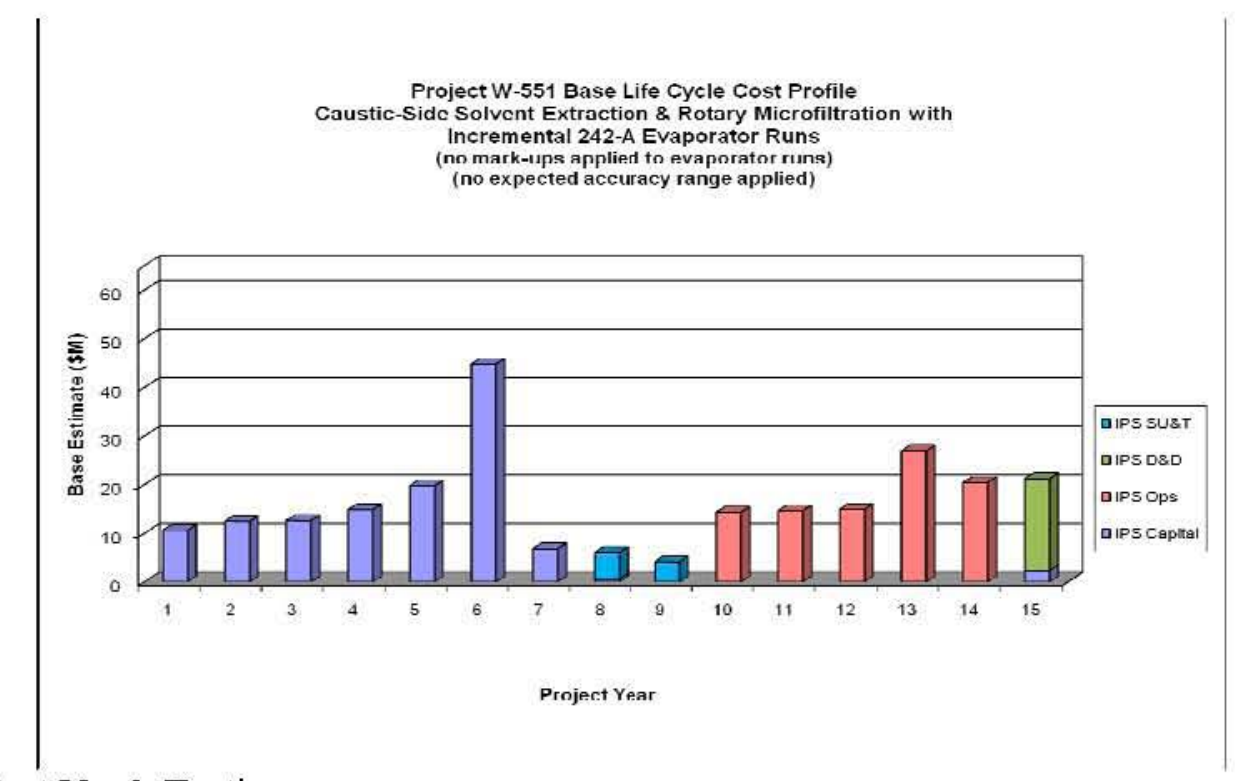

SU\&T - Start Up \& Testing

D\&D - Decontamination \& Decommissioning

ICosts estimates are for comparative purposes between the technologies only \& DO NOT reflect the total IPS project cost] 


\section{C.2. SCHEDULE ESTIMATES}

Based on the estimated durations for each of the major activities as provided by Subject Matter Experts (SMEs), implementation schedules (conceptual design through operational readiness) were developed for each of the Cs separation technologies. The major activities that were included in the three implementation schedules were: design, technology development, permitting, licensing, construction (including long-lead procurement), and construction. Duration estimates for each of these major activities were provided by SMEs. The SMEs provided optimistic ( $<25 \%$ probability of on-time completion), most probable $(50 \%$ probability of on-time completion) and pessimistic ( $>75 \%$ probability of on-time completion) schedule durations for overall design, testing, permitting, safety and licensing, construction and startup schedule activities.

Because it was assumed that both the permitting and licensing activities were driven by design (and not vice versa), the critical path in all cases was through design, construction, and start up activities.

In all cases the overall design duration of 44 months was assumed to be adequate for all alternatives and thus, was not a discriminator.

Additionally, because the IPS mission was defined as being 5 years of operations and one year for D\&D (i.e., the same for all technologies), the operations and decommissioning durations were not included.

The construction durations for each option were based on total craft labor hours from the cost estimate and an assumed crew size, resulting in the following durations for each technology pair:

- IX-sRF/RMF: 26 month

- IX-sRF/CFF: 27 months

- FC/RMF: 32 months

- FC/CFF: 32 months

- $\mathrm{CSSX/RMF:} 39$ months

- CSSX/CFF: 40 months

The startup and testing durations were estimated with help from Operations SMEs as

- IX alternatives: 14 months

- FC alternatives: 17 months

- CSSX alternatives: 21 months

As there did not appear to be a significant difference in the construction duration estimates based on the filtration technologies, it was decided to develop individual implementation schedules for each of the three Cs separation technologies, rather than for each combination of filtration and separation technologies. 
Using these duration estimates, a simplified Monte Carlo simulation was run for each of the Cs separation technologies using the duration estimates from the SMEs described above. The resulting S-curves showed that at a 50/50 probability of on-time completion, implementation of the IX-sRF process, i.e., completion of hot start up activities, would require approximately 90 months ( $7-1 / 2$ years) from the start of conceptual design. Similarly for the FC process, the duration of the implementation phase was approximately 100 months (almost 8-1/2 years) and for CSSX approximately 110 months (over 9 years). The primary differences in these schedule estimates occurred in the construction and start up phases and were attributed to the relatively increasing complexity of the FC- and CSSX-based systems.

The set of S-curves for the Cs separation technologies that was generated by the Monte Carlo simulation are shown in Figure C-9. These curves were developed for comparative purposes only.

The implementation schedules for the Cs separation technologies are shown in Figure C-10 through Figure C-12.

Figure C-9 - S-Curves for Cs Separation Technologies

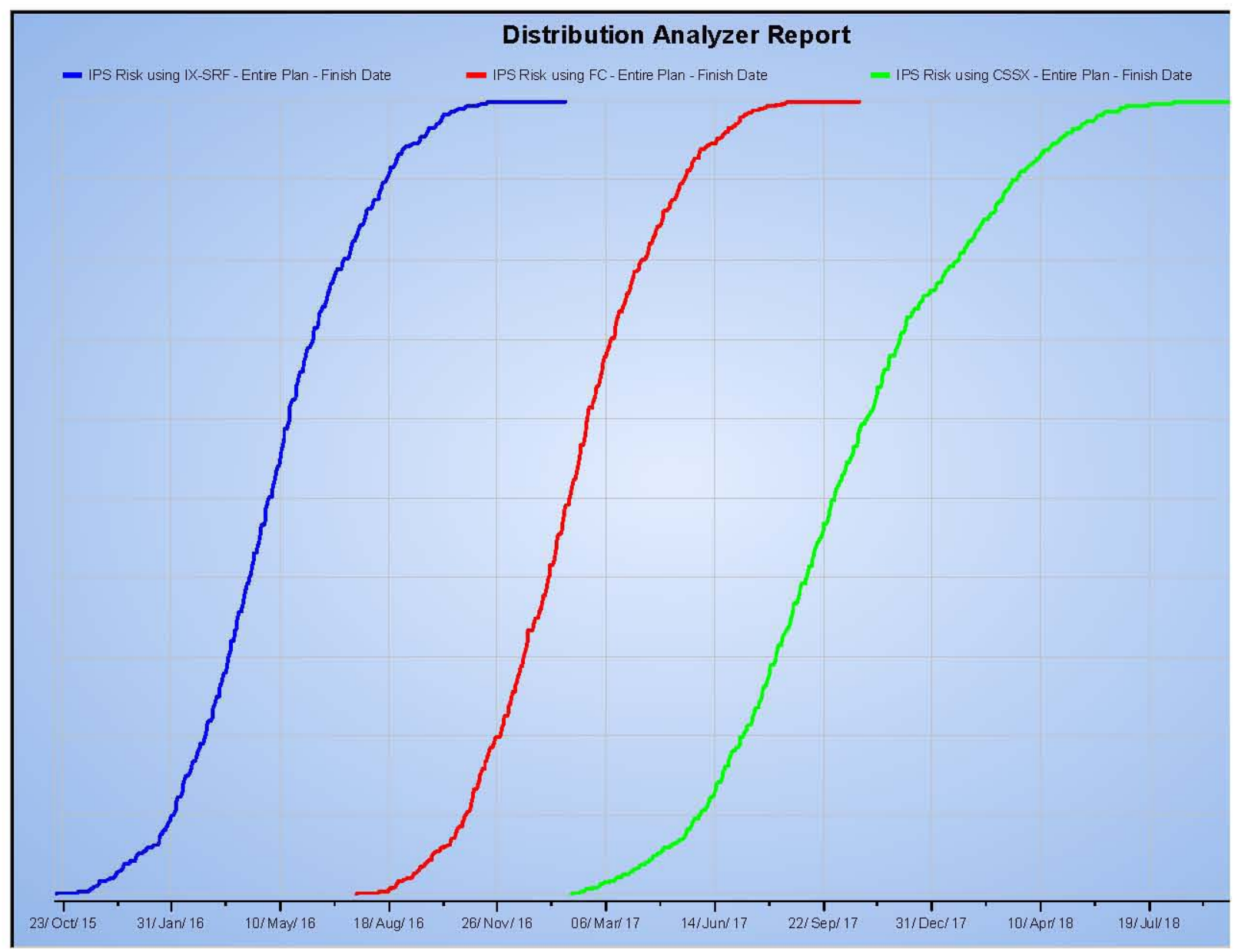


RPP-RPT-38057, Rev. 0

Figure C-10 - Implementation Schedule for IX-SRF

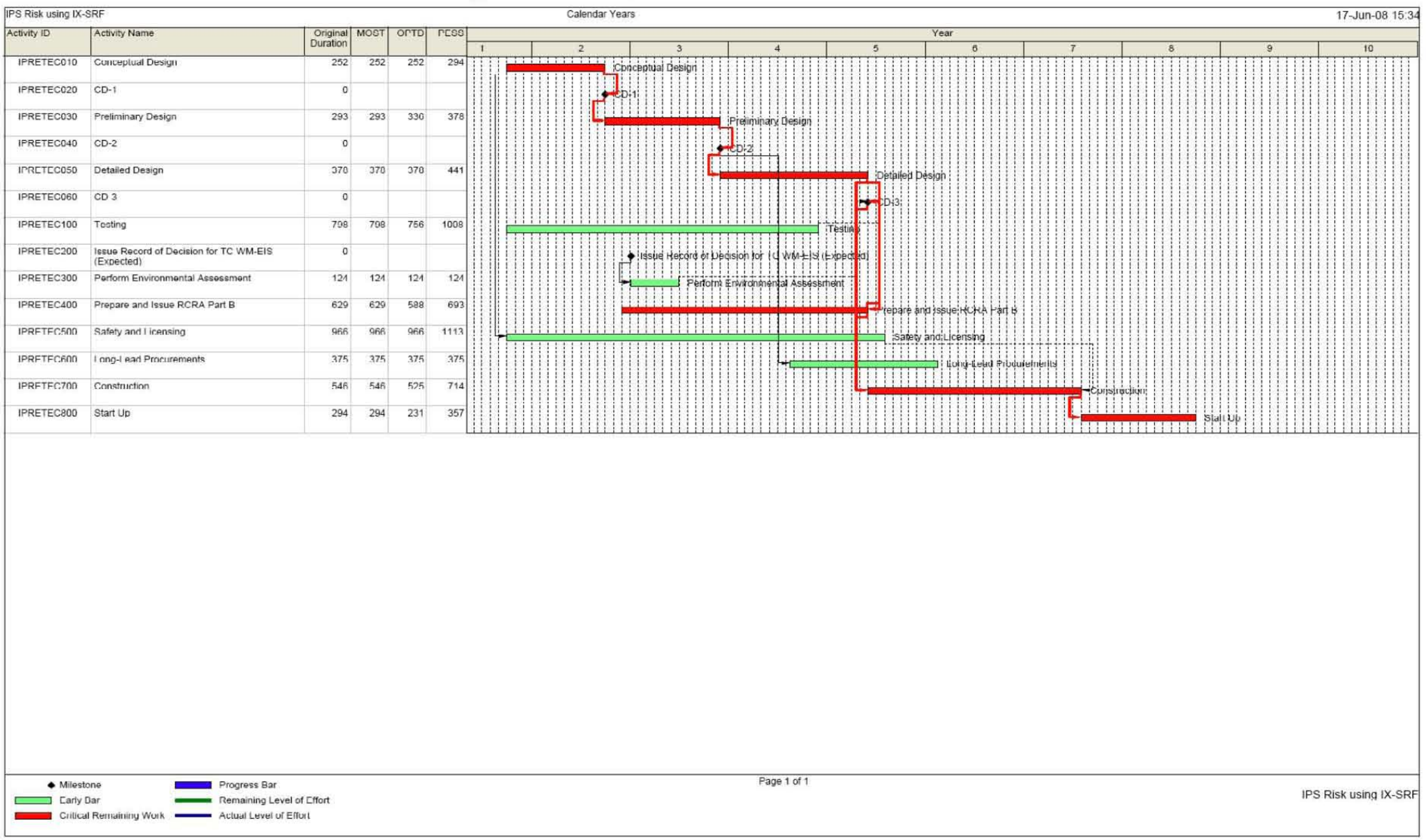


RPP-RPT-38057, Rev. 0

Figure C-11 - Implementation Schedule for FC

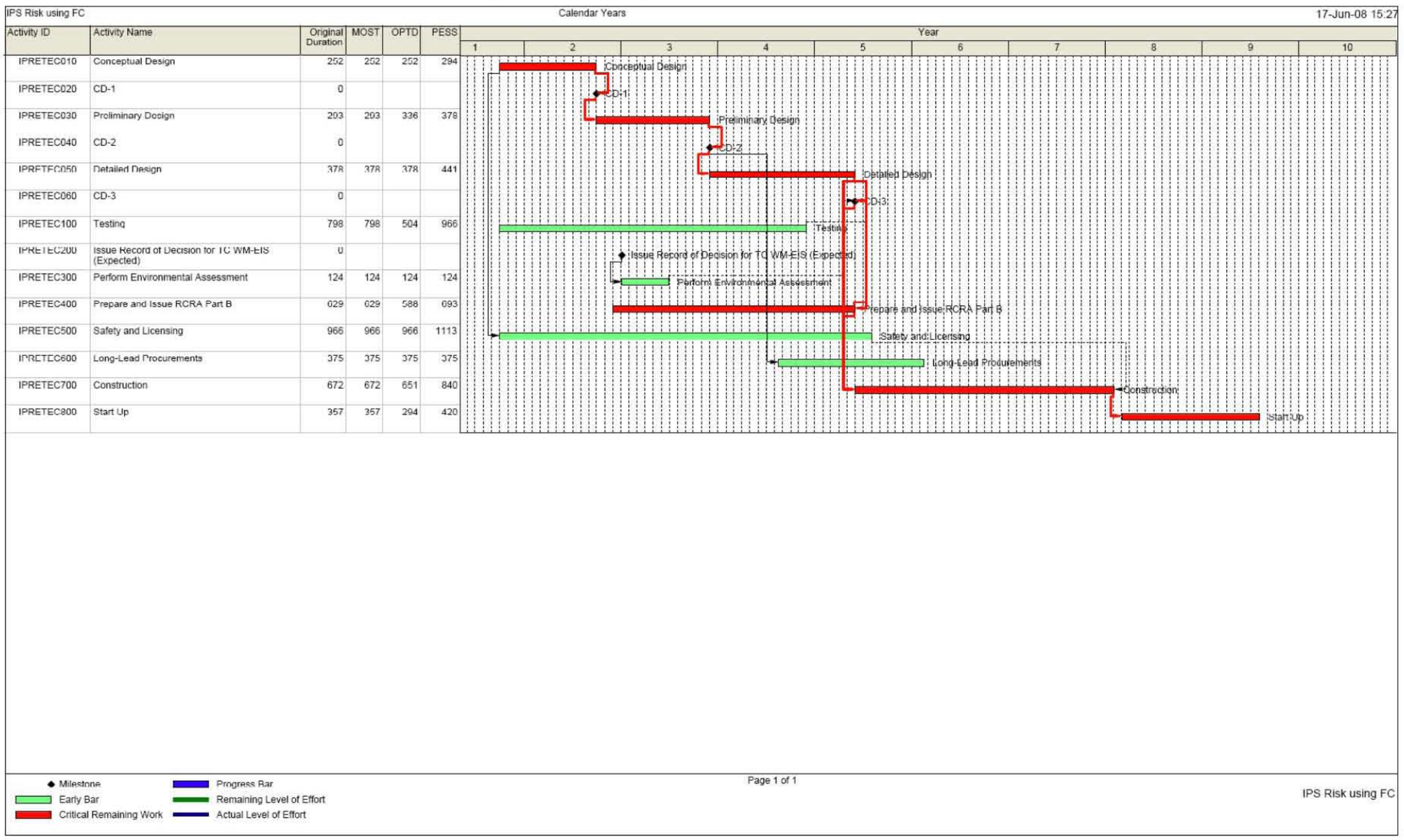


RPP-RPT-38057, Rev. 0

Figure C-12 - Implementation Schedule for CSSX

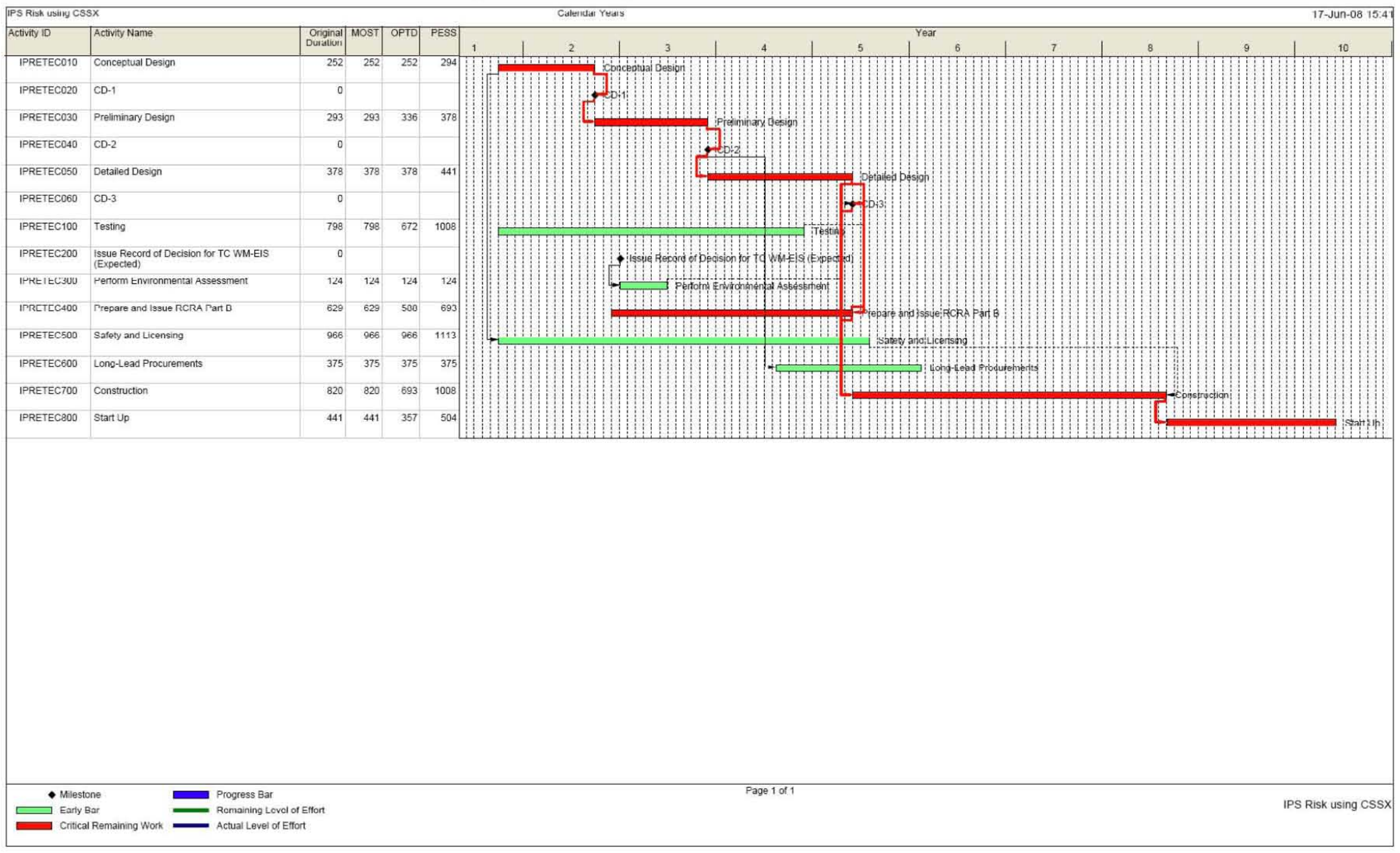




\section{ATTACHMENT D. SENSITIVITY ANALYSIS}

Limited sensitivity analysis was performed for both the solids filtration and cesium separation assessments to determine the impact of changing the point spread of the raw scores. The results of the sensitivity analysis are shown in Table D-1 and Table D-2. As can be seen from the tables, unless you apply a wide spread to the raw scores, there is no appreciable change in the results. While applying a wider spread (i.e., 1, 5, 10) to the raw scoring makes the results more distinctive, at issue is the implication that the score for the best is 10 times better than the worst and 2 times better than the middle ranking technology.

Table D-1 - Sensitivity Analysis for Solids Filtration Technologies

\begin{tabular}{|c|c|c|c|c|c|c|}
\hline \multicolumn{3}{|c|}{ SOLIDS SEPARATION } & \multicolumn{4}{|c|}{ Sensitivity Changes for Unequal Scores } \\
\hline & \multicolumn{2}{|c|}{ Original } & \multicolumn{2}{|c|}{$\begin{array}{c}\text { Increasing Delta } \\
\text { on Each Score by } \\
1 \text { (Lowest Down, } \\
\text { Highest Up) }\end{array}$} & \multicolumn{2}{|c|}{$\begin{array}{l}\text { Changing Low } \\
\text { Score to } 1 \text { and } \\
\text { High Score to } 10\end{array}$} \\
\hline & $\begin{array}{l}\text { Base } \\
\text { CFF }\end{array}$ & $\begin{array}{l}\text { Base } \\
\text { RM }\end{array}$ & $\begin{array}{l}\text { CFF } \\
+/-1\end{array}$ & $\begin{array}{c}\mathbf{R M}+/- \\
\mathbf{1}\end{array}$ & $\begin{array}{c}\text { CFF 1- } \\
10\end{array}$ & $\begin{array}{c}\text { RM 1- } \\
10\end{array}$ \\
\hline Safety & 12 & 12 & 12 & 13 & 11 & 14 \\
\hline Regulatory & 10 & 11 & 10 & 11 & 10 & 11 \\
\hline $\begin{array}{l}\text { Technical } \\
\text { Maturity }\end{array}$ & 12 & 11 & 12 & 11 & 13 & 11 \\
\hline Operations & 8 & 7 & 8 & 7 & 10 & 5 \\
\hline Programmatic & 12 & 8 & 13 & 7 & 17 & 5 \\
\hline Total & 54 & 49 & 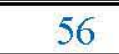 & 47 & 61 & 46 \\
\hline
\end{tabular}

Table D-2 - Sensitivity Analysis for Cs Separation Technologies

\begin{tabular}{|c|c|c|c|c|c|c|c|c|c|}
\hline \multicolumn{4}{|c|}{ CESIUM SEPARATION } & \multicolumn{6}{|c|}{ Sensitivity Changes for Unequal Scores } \\
\hline & \multicolumn{3}{|c|}{ Original } & \multicolumn{3}{|c|}{$\begin{array}{c}\text { Increasing Delta on } \\
\text { Lowest and Highest } \\
\text { Score by } 1 \text { (Lowest } \\
\& \text { next lowest down } \\
1 \text { and Highest Up } 1 \text {, } \\
\text { Duplicates same } \\
\text { action) }\end{array}$} & \multicolumn{3}{|c|}{$\begin{array}{l}\text { Changing Range for } \\
\text { all Scores (Lowest to } \\
1, \text { Middle to } 5, \\
\text { Highest to } 10, \\
\text { Duplicates same } \\
\text { action) }\end{array}$} \\
\hline & $\begin{array}{c}\text { Base } \\
\text { FC }\end{array}$ & $\begin{array}{c}\text { Base } \\
\text { CSSX }\end{array}$ & $\begin{array}{c}\text { Base } \\
\text { IX }\end{array}$ & $\begin{array}{l}\text { FC } \\
+/-1\end{array}$ & $\begin{array}{c}\text { CSSX } \\
+/-1\end{array}$ & $\begin{array}{c}\text { IX } \\
+/-1\end{array}$ & $\begin{array}{c}\text { FC } \\
1-10\end{array}$ & $\begin{array}{c}\text { CSSX } \\
1-10\end{array}$ & $\begin{array}{c}\text { IX } \\
1-10\end{array}$ \\
\hline Safety & 13 & 11 & 11 & 14 & 10 & 10 & 19 & 10 & 8 \\
\hline Regulatory & 11 & 9 & 11 & 10 & 8 & 12 & 10 & 6 & 13 \\
\hline $\begin{array}{l}\text { Technical } \\
\text { Maturity }\end{array}$ & 9 & 7 & 9 & 11 & 6 & 9 & 17 & 5 & 15 \\
\hline Operations & 8 & 6 & 8 & 7 & 5 & 9 & 9 & 3 & 12 \\
\hline Programmatic & 11 & 8 & 11 & 11 & 6 & 11 & 13 & 4 & 13 \\
\hline Total & 51 & 41 & 50 & 53 & 35 & 51 & 68 & 28 & 61 \\
\hline
\end{tabular}


RPP-RPT-38057, Rev. 0

\section{ATTACHMENT E. DECISION SUPPORT BOARD BIOGRAPHICAL SUMMARIES}

\section{Jim Honeyman, Chairman}

Jim Honeyman has over 33 years of experience within the DOE weapons complex, encompassing a wide range of strategic and tactical planning, process design and development, program management, program alternative evaluation, contingency planning for both weapons material processing and environmental clean up. Mr. Honeyman is skilled in chemical engineering process design and analysis, new venture feasibility assessment, technology implementation, NEPA processes, regulatory compliance, and stakeholder involvement. He also has experience across a broad range of program areas that includes DOE complex-wide nuclear materials production, DOE Site Cleanup technology and planning, recovery and waste management; weapons fabrication technologies and compliance issues; startup planning for contingency capabilities. Mr. Honeyman has participated in numerous project validation and review efforts conduct by DOE and its predecessor agencies, and has extensive experience in what is required to be successful in these reviews. Highlights of Mr. Honeyman's accomplishments include:

- Developed the first integrated cleanup plan for the Hanford site (Hanford Site Mission Plan) that serves as a blueprint for cleanup today

- Led the initial competitive demonstration of vitrification of Hanford LAW wastes

- Led the negotiation of the technical basis for the Interim Stabilization Consent Order, and led the development of the implementation plan

- VP for interim design of the Waste Treatment Plant after BNFL termination, responsible for operations planning, Research and Technology, AB, and flowsheet validation

- Led the development of the first of a kind Tank Farm Industrial Hygiene Technical Basis

- Led the development of the LAW first concepts for early treatment of Hanford Tank Wastes

\section{Jim Badden}

Jim Badden has over 30 years of experience in the nuclear industry to include 26 years of management experience. In addition, he has six years of commercial project management experience. This encompasses construction projects, commercial reactor refueling outages, commercial reactor upgrades, nuclear waste management facility designs, nuclear waste management planning and scheduling, nuclear waste management operations, and safety analysis development. Mr. Badden's professional accomplishments include maintaining, operating, and upgrading the single and DSTs for transition to interim closure; providing direction regarding status of equipment 
operability and compliance with operational safety requirements and operational safety documents related to the safe storage of waste in the $200 \mathrm{E}$ and $200 \mathrm{~W}$ Tank Farms. He also provided direction in writing the functional design criteria for the Dry Materials Grout Facility, the initial Grout Vault conceptual design report. Mr. Badden was also the operation manager during the AP Farm initial start up and Operational Readiness Reviews for the 242-A Evaporator and the New Cross-Site Transfer line.

\section{P. K. Brockman (alternate)}

P.K. Brockman has over 25 years of Operations, Business Development, and Program and Project Management experience in radioactive waste stabilization and treatment, environmental engineering, nuclear waste management, remediation planning, site characterization and construction related project activities. Mr. Brockman has been responsible for the management and direction of a multi functional engineering consulting services operation with over 200 professional engineering and scientific staff with an annual budget in excess of \$50M. Mr. Brockman was responsible for the oversight and performance of a previous company's largest single project with revenues in excess of $\$ 110 \mathrm{M}$. Currently Mr. Brockman provides senior leadership to the Hanford Tank Farms Project Delivery organization which provides supplemental treatment options for the final disposal of tank farm wastes, management of tank farm construction projects and management of tanks farm start up and testing readiness activities in a highly regulated and visible public arena.

\section{Kris Colosi,}

Kris Colosi is a project manager with over 20 years in project management and engineering. Ms. Colosi's background includes successful management of design, construction and startup of primary tank waste ventilation systems for the aging waste tanks, cross site transfer system, K-basin water treatment system for spent fuel retrieval, high level waste storage facility and low level disposal landfill at the Hanford Reservation. Prior to working at the Hanford Reservation, Ms. Colosi worked on five commercial nuclear reactor facilities providing engineering support during construction and operations. She has a bachelor's degree in mechanical engineering and master's $n$ engineering and technology management.

\section{Beth Conrad}

Beth Conrad has over 25 years of experience in nuclear materials management, processing, safety and operations at Hanford, Rocky Flats, and in the UK. Ms. Conrad recently returned to the Hanford site after a 2 year assignment supporting the United Kingdom Atomic Energy Authority (UKAEA) in the management and disposition of nuclear material and waste, primarily at the Dounreay Site. Her professional background includes the successful return to Dounreay of thorium nitrate material located in Peru, analysis, direction and strategy development on technical and safety issues associated with the storage, stabilization, and shipment of Rocky Flats plutonium metal, oxide and residues and technical support to DOE-HQ, DOE-Albuquerque and DOE-Rocky Flats ranging from plutonium production to nuclear and criticality safety oversight to the 
establishment of the DOE Facility Representative qualification requirements for Sandia Explosive Components Facility.

\section{Felix Miera}

Felix Miera is a Senior Environmental Manager for CH2M HILL, with over 30 years experience developing and managing complex multi-disciplinary radioactive and hazardous waste environmental cleanup projects. His experience includes tenures with State governments as a manager and regulator, and with the federal government and private industry as a compliance specialist and project manager. Mr. Miera's project experience includes the development of innovative strategies for mitigating releases of radioactive mixed waste, implementing selected alternatives for cleanup of radioactive mixed waste, and the development and negotiation of innovative approaches to obtain environmental regulatory permits in a timely manner.

\section{Rick Raymond}

Mr. Richard E Raymond is currently the Director of Technology Development and the Director of Engineering Standards. In this position, he manages the development and deployment of new technologies and he manages the development of engineering procedures and senior technical support for all Tank Farm operations. In his previous position of Vice President of Projects he was responsible for full service project management of multi-disciplined, multi-year capital line item and expense projects, including engineering, construction, procurement, quality, safety, environmental compliance, and start-up/testing. Other assignments include a variety of engineering, operations, and program/project management roles, including Plant Manager for the Hanford N-Reactor, Director of Reactor Engineering, Director of Plant Engineering, Chief Engineer for the Hanford Tank Farms, and Reactor Engineer with U.S. Department of Energy on the Headquarters staff of Admiral H. G Rickover in the Division of Naval Reactors. He has a Bachelor of Science from the University of Washington in Electrical Engineering, Masters Degree in Nuclear Engineering, and has completed advanced nuclear reactor operational training with the U.S. Navy. Mr. Raymond also serves as an adjunct member of the faculty and Chairman of the Advisory Board of the Walla Walla College of Engineering, and Chairman of the Advisory Board for the Applied Research Center for Florida International University. 